FACULDADE DE CIÊNCIAS FARMACÊUTICAS

Curso de Pós-Graduação em Ciência dos Alimentos

Area de Bromatologia

\title{
HIDROLISADO DE COLÁGENO UTILIZAÇÃO BIOLÓGICA EM MISTURAS PROTÊICAS E SEU EFEITO NO TECIDO CUTÂNEO
}

MARIA ELIZETTE RIBEIRO

Tese para obtenção do título de DOUTOR

Orientador:

Prof. Assoc. Massami Shimokomaki 


\section{HIDROLISADO DE COLÁGENO UTILIZAÇÃO BIOLÓGICA EM MISTURAS PROTÊICAS E SEU EFEITO NO TECIDO CUTÂNEO}

Comissão Julgadora

Tese para obtenção do título de DOUTOR

Prof. Assoc. Massami Shimokomaki

Presidente

Prof. Dr. Pedro Alves da Rocha Filho

$1^{\circ}$ Examinador

Profa. Assoc. Telma Maria Tenório Zorn

$2^{\circ}$ Examinador

Profa. Tit. Érika Rosa Maria Kedor

$3^{\circ}$ Examinador

Profa. Assoc. Silvia Maria Franciscato Cozzolino

$4^{\circ}$ Examinador

São Paulo 09 de $0 Z$ de 19915. 
AMIGo, aquele que, com um toque indelével de amor, num olhar, num pensamento, num ato, num conselho, num carinho, contribue para que eu me aproxime cada vez mais de minhas metas.

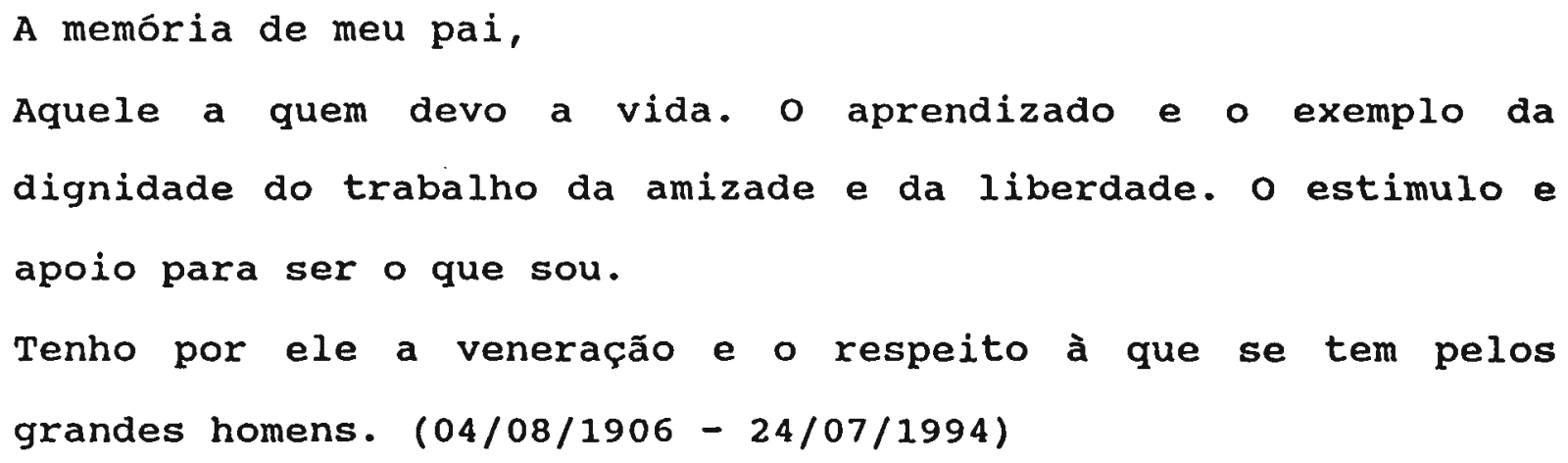

A minha mãe Salette

Ao meu marido Nonato

Aos meus filhos Roberto e Thais

Ao amigo Helio dos Santos

Aos meus irmãos e amigos

A estes, quase imperceptrveis, incorporados ao meu dia a dia, dedico esta tese. 


\section{AGRADECIMENTOS}

Ao Prof. Massami Shimokomaki pela orientação e amizade.

Ao Prof. Carlos Ribeiro Vilela pela amizade e revisão do texto.

A Prof a Telma M.T. Zorn e Sergio Ferreira de Oliveira pelos laudos histológicos.

A Prof Silvia Berlanga de Moraes Bastos pelos laudos patológicos.

A Profa Silvia Cozzolino e Celia Colli pela colaboração.

A Profa Ursula M. Lanfer pela analise dos aminoácidos.

A Mirtes Eliete Velletri de Souza pelo apoio, amizade e estímulo.

Ao Dr. George Mac Cruz pela amizade e colaboração em anatomia patologica.

Ao Edson Facuri e Sergio Nakamura pelo trabalho de computação e gráficos.

A Regina Vilella e Jamil Aneas pelo estímulo e cooperação.

A Faculdade de Farmácia e ao Departamento de Alimentos pela oportunidade. 
2-REVISÃo DA LITERATURA....................... 03

2.1-Recuperação e aproveitamento

de subproduto de abatedouro....................

2.2-Proteínas do tecido conjuntivo........... 05

2.3-Pele como fonte de colágeno............... 18

2.4-Colágeno como matéria prima para a indústria... 20

2.5-Caracteristicas da pele................ 27

2.6-Metabolismo proteico.................. 33

3-OBJETIVo......................... 46

4 -MATERIAL. ........................ 47

4.1 -Animais.......................... 47

5-MÉтоDos............................ 48

5.1-Avaliação do valor biológico da proteína......448

5.2-Determinação do coeficiente de

digestibilidade aparente.............. 48

5.3-Avaliação da umidade na ração............. 49

5.4-Determinação de lípides na ração........... 49

5.5-Determinação de nitrogênio total na ração..... 49

5.6-Composição e preparo das rações............449

5.7 -Procedimento experimental............. 56

5.8 -Ensaios biológicos................. 56 
5.9-Análise estatística................ 56

5.10-Doseamento de hidroxiprolina........... 56

5.11-Verificação histológica do colágeno da pele... 56

5.12-Exame histopatológico de fígado, rim e histológico de pele......................... 57

5.13-Análise de aminoácidos............... 57

6-RESUltados E discUSSĀo.................. 58

6.1 -Composição centesimal da ração............ 58

6.2 -Valor biológico das raçōes..............6 61

6.3-Composição aminoacídica das rações.......... 77

6.4-Avaliaçāo histopatológica do fígado e rim.......99

6.5-Avaliação histológica do tecido cutâneo........ 95

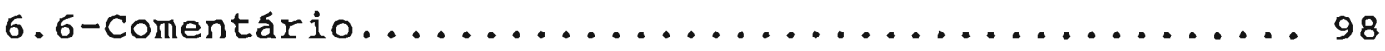

7 -CONCLUsões............................. 106

8 -RESUMo. . . . . . . . . . . . . . . . . . . . . . 107

9-SUMMARY .......................... 108

10-REFERENCIAS BIBLIOGRÁFICAS................ 109 


\section{1 - INTRODUÇÃO}

o desafio de vencer a escassez mundial de alimento, especialmente proteína de boa qualidade, é um problema que ocupa lugar especial dentro da comunidade cientifica, que se preocupa em discutir, estudar e tentar encontrar soluções alternativas de alimentação a curto e médio prazo, a fim de minimizar $\circ$ panorama alarmante da fome que atinge principalmente as crianças em termos de seu crescimento e desenvolvimento, já que a deficiência prolongada de proteína leva ao retardamento no desenvolvimento físico e mental. Desta forma, está se tornando evidente que os métodos clássicos de produção de proteína animal não estão atendendo à demanda, diante disso, há necessidade de se desenvolver e explorar outras fontes de proteína.

Por outro lado, se houvesse uma politica alimentar perfeita, ainda assim, existiria escassez de alimentos, especialmente proteína, em muitos países, devido à desigualdade entre produção e capacidade de distribuição destas proteinas (KINSELLA， 1978; BRANT, 1980; DOVER \& TALBOT, 1987; GREENWOOD, 1989) .

De acordo com o exposto, o interesse em aumentar a produção de proteínas vegetais e animais e em desenvolver novas fontes de alimentos protéicos tem aumentado muito, de tal forma que avanços nesta área tem sido observados. Recentes pesquisas tecnológicas para desenvolver produtos semelhantes à carne têm obtido sucesso, quanto à flexibilidade do material desejado, favorecendo com isso as características de textura e paladar. A 
ausência de qualidade organoléptica e o alto custo dos produtos semelhantes à carne, obtidos de fontes vegetais, animais ou bacterianas, parecem incentivar uma avaliação nutricional das proteínas dos residuos de abatedouro. Essas proteínas fazem parte de orgãos animais que não preenchem os requisitos de aparência e textura que agradem a maioria dos consumidores (GREENWOOD, 1989) .

A pele bovina é um subproduto rico em colágeno. Estudos tem-se ampliado no sentido de adequa-la a alimentação humana. Nosso estudo tem a finalidade de correlacionar o valor nutricional de mistura desta proteína com sua participação na formação do tecido cutâneo bem como a importáncia do enriquecimento com prolina no crescimento dos ratos. 
2.1 - Recuperação e aproveitamento de subprodutos de abatedouro

Com o crescente aumento da população mundial e a escassez dos alimentos de alta qualidade e baixo custo, principalmente em áreas subdesenvolvidas, a utilização e recuperação de residuos mostram-se necessárias e desafiam as indústrias de alimentos a desenvolver novas tecnologias para o seu aproveitamento. Por outro lado, a produção de proteinas a partir de fontes não convencionais de alimentos oferece uma possibilidade para minimizar as diferenças entre população e fornecimento de alimentos (BEN-GERA \& KRAMER, 1969; WU \& BATES, $1975)$.

A transformação de um produto a partir da conversão de residuos em subprodutos, a coprodutos e, finalmente a produto principal é um processo demorado, estimulado e conduzido pelas necessidades, conhecimento acumulado, problemas econômicos e legislação a nível mundial ou em áreas localizadas (BEN-GERA \& KRAMER, 1969) .

Intensos esforços, por parte de laboratórios industriais e institucionais durante os anos 60 , destacaram a importância e a necessidade urgente da utilização de proteĺnas a partir de matéria-prima não convencional ou sub utilizada (TOMBS, 1974; WU \& BATES, 1975).

Paralelamente, busca-se reestruturar estas proteinas não convencionais, conferindo-lhes caracteristicas de textura 
aceitáveis, semelhante à proteína animal tradicional (WU \& BATES, 1975; KINSELLA, 1978).

Pelo alto custo investido nos métodos convencionais de produção de alimentos, deve-se partir para a investigação de processos mais eficientes, que minimizem as perdas ou subutilização de fontes protéicas nobres (AREAS, 1986; KINSELLA, 1978; LAWRIE, 1985; WEISBERG, 1976; YOUNG \& LAWRIE, $1974 \mathrm{a}$ e b). Entretanto, o desenvolvimento de novos produtos protéicos requer uma avaliação da qualidade nutricional e das propriedades funcionais dos mesmos.

Propriedades funcionais são aquelas caracteristicas físico-químicas que influem no comportamento dos ingredientes nos sistemas alimentícios durante a preparação, processamento, armazenamento e consumo (KINSELLA, 1978 e 1979; MARTINEZ, 1979; HERMANSSON, 1983; VISSER \& THOMAS, 1987). Incluem-se nestas características a solubilidade, estabilidade térmica, capacidade de formar géis e de emulsificar. o conhecimento das propriedades funcionais é importante não só para determinar a qualidade de um produto final, mas também para delinear e otimizar processos (AREAS\& LAWRIE, 1984; LAWRIE, 1981; SWINGLER \& LAWRIE, 1978; YOUNG \& LAWRIE, 1974a e b; YOUNG \& LAWRIE， 1975) •

As propriedades funcionais encontradas nas proteinas do tecido conjuntivo "fibras colágenas", fazendo parte de subproduto de abatedouro como pele, tendão, ossos e vísceras. 


\title{
2.2 - Proteínas do tecido conjuntivo
}

\author{
2.2 .1 - Coláqueno \\ - colágeno é uma proteína fibrosa encontrada em todos
} os organismos animais multicelulares. E a mais abundante proteina animal, constituindo um quarto do total protéico, e o principal elemento fibroso da pele dos mamiferos, ossos, tendões e dentes. Está presente em quantidade variáveis em quase todos os orgãos e contribui para exercer ação de suporte na estrutura geral dos tecidos. A propriedade caracteristica de alguns tipos de colágeno é que ele forma fibras insolúveis com alta força de sustentação (JUNQUEIRA \& CARNEIRO, 1994).

As fibras colágenas são birrefringentes, constiturdas por moléculas alongadas e paralelas. Desse modo, quando examinadas ao microscópio de polarização, entre dois prismas de Nicol cruzados, estas fibras mostram-se brilhantes, contra um fundo escuro. Em muitos tecidos, as fibras colágenas estão agrupadas em arranjo paralelo, formando feixes de fibras. Por serem longas e de trajeto tortuoso, sua morfologia não é facil de ser estudada nos cortes histológicos. Tem diâmetro variável entre 1 e $20 \mu \mathrm{m}$ e mostram uma estriação longitudinal, devido ao fato de serem constituidas por fibras com diametro de 0,02 a $0,2 \mu \mathrm{m}$. A microscopia eletrônica demonstrou que cada fibrila é, por sua vez, constituida por filamentos mais finos. As fibras colágenas têm uma estriação transversal típica, sendo facilmente identificadas nas micrografias eletrônicas. Essa estriação aparece por períodos de $64 \mathrm{~nm}$, cada periodo formado por duas faixas uma clara e outra escura (FIGURA 1). As faixas 
escuras fixam maior quantidade de substancia contrastante usada na impregnação para a microscopia eletrônica (JUNQUEIRA \& CARNEIRO, 1994).

As fibras colágenas são constituídas por uma escleroproteína denominada colágeno com composição de aminoácidos bem característica. O aminoácido glicina está presente na proporção de $35,5 \%$, enquanto que a prolina e a hidroxiprolina na proporção de 12 e $10 \%$, respectivamente. 0 restante é formado por vários aminoácidos, sendo interessante notar que carece de aminoácidos sulfurados e de triptofano. o colágeno é a única proteína que contém quantidade apreciável de hidroxiprolina, apenas a elastina contém essa substância, porém em quantidades insignificantes, permitindo assim que o teor de colágeno de um tecido possa ser determinado pela dosagem de hidroxiprolina (JUNQUEIRA \& CARNEIRO, 1994).

\section{Tipo de Colágeno}

Existem 18 tipos de colágenos descritos na literatura. Para os tipos de colágenos formadores de fibras o colágeno antigamente conhecido por tropocolageno é a unidade protéica que quando polimerizada forma as fibras colágenas, é uma molécula alongada, assimétrica, que mede $280 \mathrm{~nm}$ de comprimento e $1,5 \mathrm{~nm}$ de espessura, é formada por três cadeias peptídicas enroladas em hélices, da esquerda para a direita (FIGURA 2). Das três cadeias peptídicas duas têm a mesma seqủência de aminoácidos e são denominadas alfa 1 e a outra, que tem diferente esquema de aminoácldos, é denominada alfa 2. 
Estudos realizados em cartilagem hialina mostram que - colágeno principal deste tecido contém apenas um tipo de cadeia alfa, diferente das cadeias alfa 1 e alfa 2 descritas inicialmente. A cadeia encontrada na cartilagem tem composição mais parecida com a da cadeia alfa 1 do que com a da cadeia alfa 2 dos outros tecidos, tendo sido designada defl(II) ou alfa 1 tipo II. A cadeia alfa 1, previamente descrita, passou a ser chamada de $\alpha_{1}$ (I) ou alfa 1 Tipo I. o colageno mais comum é caracterizado pela composição $\alpha\{1(I)\} 2$ e agora designado colágeno Tipo I e o da cartilagem, com a composiçãof\{1(II)\}3, é conhecido como colágeno Tipo II. Todavia, há ainda outras variedades bioquímicas de colágeno, como o Tipo III, com constituição $\mathcal{Q}\{1($ III) $\} 3$ e que foi detectado na parede das artérias, na pele e no utero (quadro 1), sempre em quantidade muito menor do que o colageno do Tipo I. As laminas basais possuem colágeno do Tipo IV, constituldas por 3 cadeias alfa 1 Tipo IV. Sua estrutura seria a seguinte $\{\{1$ (IV) $\} 3$.

As cadeias de colágeno dos tipos $V$ e XI têm caracteristicas semelhantes àquelas descritas acima na formação de fibras. Entretanto, os tipo IX e XII não formam fibras e apresentam uma certa homologia entre eles (PIEZ, 1984; MILLER, 1985; KUHN, 1987; SHIMOKOMAKI, et al, 1990).

o colágeno tipo IX está presente em todas as cartilagens hialinas. Constitui aproximadamente entre 5-20\% do colágeno total (SHIMOKOMAKI, 1982). Foi originalmente descrita em cartilagem articular de suinos (SHIMOKOMAKI et al. ,1980, 1981; SHIMOKOMAKI, 1982), porém a sua estrutura tem sido 
estudada com mais detalhes em esterno de aves (REESE \& MAYNE, 1981).

o colágeno tipo $\mathrm{x}$ foi descoberto ao mesmo tempo por dois laboratórios independentemente (SCHIMID \& CONRAD, 1982). A sua distribuição é restrita e é sintetizada somente pelos condrócitos hipertróficos (SCHIMID \& LINSENMAYER, 1987).

- colageno tipo XI foi originalmente isolado da cartilagem articular de humanos (BURGESON \& HOLLISTERD, 1979) e constitui cerca de 5-10\% do colágeno total (SHIMOKOMAK̇I, 1982, 1989). 


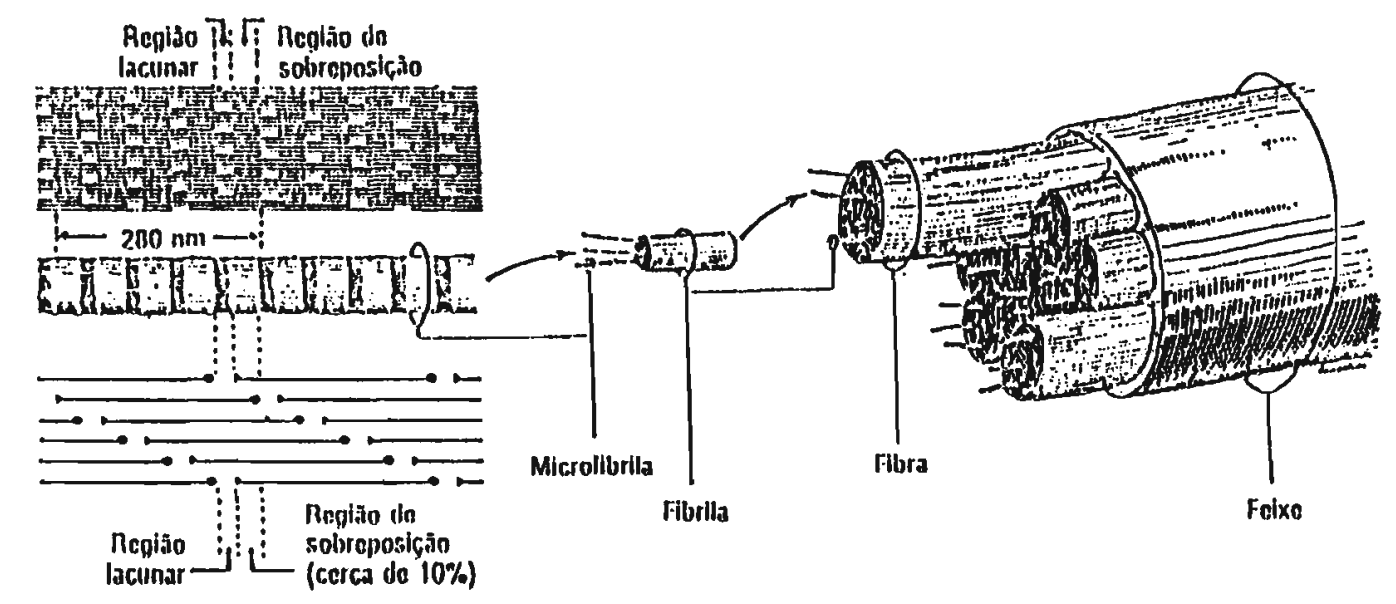

FIGURA 1- ESTRUTURA DAS MICROFIBRILAS, FIBRAS E FEIXES DO COLÁGENO ( JUNQUETRA \& CARNEIRO 1979 )

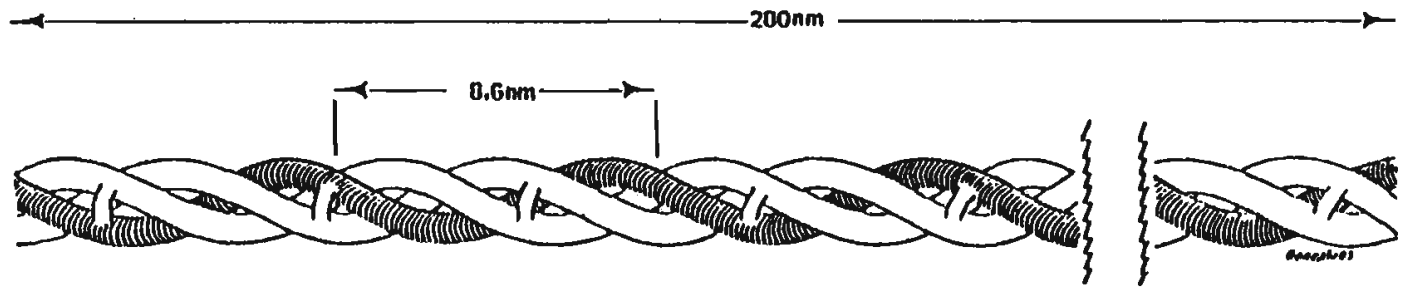

Figura 2- molecula de procolageno ( JUNQUetra \& CARNEIRo 1979) 


\section{BIOSINTESE do COLÁGENO}

\section{COMPABIIMENTO CELULAR}

EIARAS

Núcleo

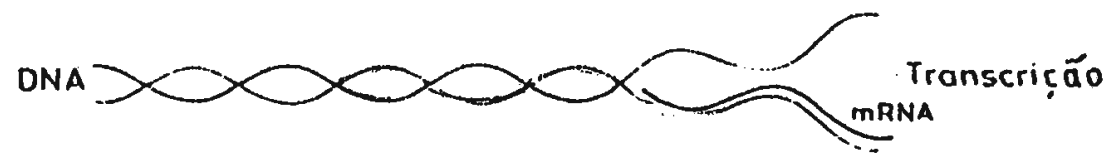

Membrana de Reticulum Endoplósmico

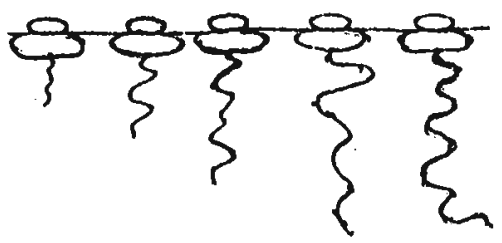

Traduçăo

Tubos de

Reticulum

Endoplásmico

Roticulum Endoplásmico Liso

Aporeltho de Golgi
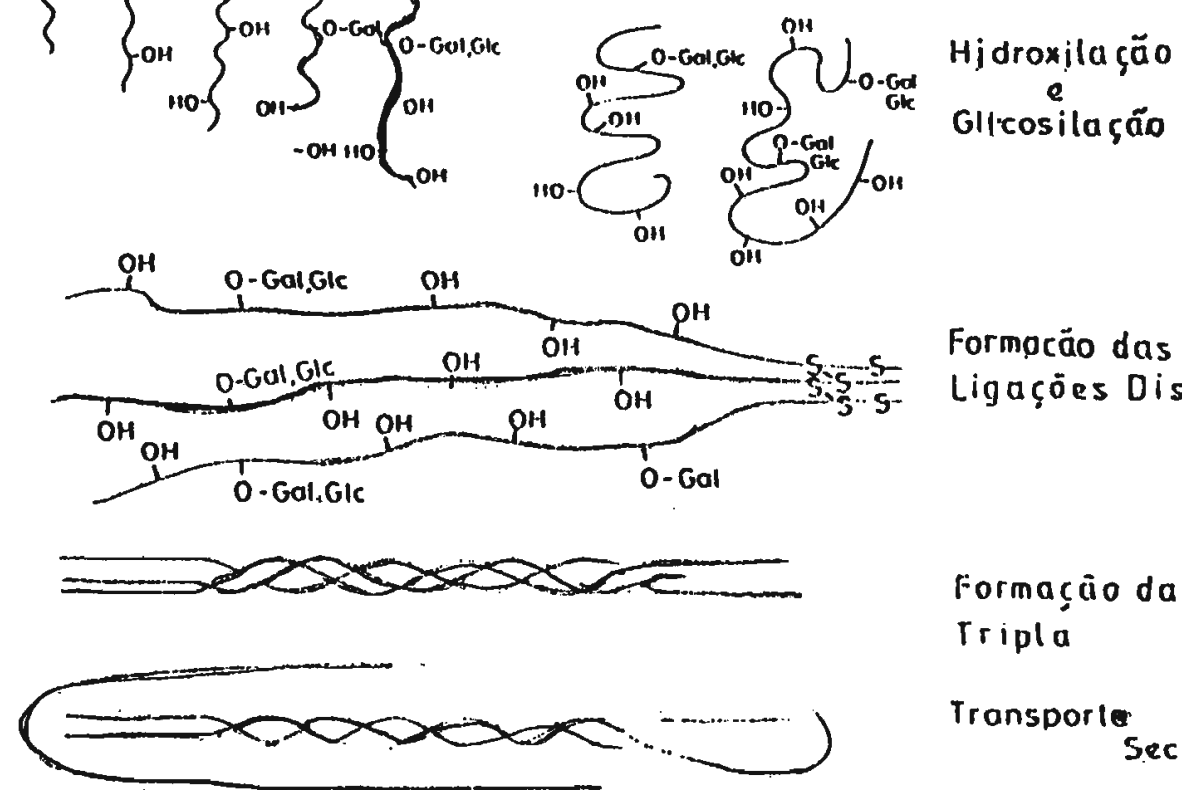

Formacäo das

Ligaçōes Disulfídicas

Formaçóo da Héllx rripla

Transporle
Secreģo

Conversāo do Procolágenl

a Colágeno

Formação das Fibrilas

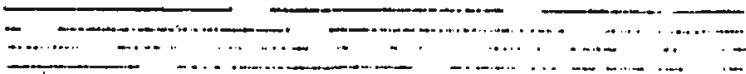

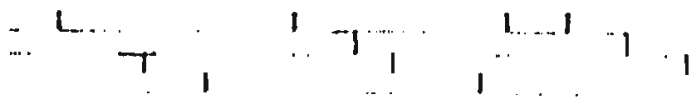

Formacáo da Ligacäo Cruzada

FIGURA 3- ETAPAS DA BIOSTNTESE DO COLAGENo. de acordo com 
QUADRO 1 - Agrupamentos dos tipos de colágenos de vários tecidos com propriedades de agregamento e subseqüente formação (associados ou não) das fibras, comparados com aqueles presentes em cartilagens. Observar que a cartilagem contém os colagenos tipos II (formadores), IX e XI (associados), e finalmente X (não associados), (SHIMOKOMAKI et al. 1980, 1981, 1982, 1989), (SCHIMID \& LINSENMAYER 1987), (PIEZ 1984)

\begin{tabular}{|c|c|c|c|c|c|c|}
\hline & Tendão & Músculo & Pele & Osso & Arteria & $\begin{array}{l}\text { Carti- } \\
\text { lagem }\end{array}$ \\
\hline $\begin{array}{l}\text { Formadores de } \\
\text { Fibras }\end{array}$ & $I$ & $\begin{array}{c}\text { I } \\
\text { III }\end{array}$ & $\begin{array}{c}I \\
\text { III }\end{array}$ & $I$ & $\begin{array}{c}I \\
\text { III }\end{array}$ & II \\
\hline $\begin{array}{l}\text { Associados às } \\
\text { Fibras }\end{array}$ & $\begin{array}{c}\mathrm{V} \\
\mathrm{XII}\end{array}$ & $\begin{array}{c}v \\
---\end{array}$ & $\begin{array}{c}v \\
---\end{array}$ & $\begin{array}{c}v \\
---\end{array}$ & $\begin{array}{c}v \\
---\end{array}$ & $\mathrm{XI}$ \\
\hline $\begin{array}{l}\text { Não Asssociados } \\
\text { às Fibras }\end{array}$ & $\begin{array}{l}--- \\
--- \\
--- \\
--- \\
---\end{array}$ & $\begin{array}{l}\text { IV } \\
--- \\
---\end{array}$ & $\begin{array}{l}\text { IV } \\
\text { VI } \\
\text { VII } \\
---\end{array}$ & $\begin{array}{l}--- \\
--- \\
--- \\
--- \\
---\end{array}$ & $\begin{array}{l}\text { VI } \\
\text { VI } \\
--- \\
\text { VII } \\
---\end{array}$ & $\begin{array}{c}--- \\
--- \\
--- \\
--- \\
x\end{array}$ \\
\hline
\end{tabular}

--- ausente 
As fibras colágenas são acidófilas, corando-se de róseo pela técnica de hematoxilina-eosina, de azul pelo tricômio de Mallory e de verde pelo de Masson. Deve-se notar que esses métodos são apenas de coloração histologica e que existem técnicas histoquímicas que evidenciem alguns tipos de colágeno de modo específico (JUNQUFIRA \& CARNEIRO, 1994).

\section{Biossintese do colágeno}

Do tecido conjuntivo que está em fase ativa de fribrilogênese, isto é, durante o crescimento, ou em processo de regeneração cicatricial, pode-se extrair várias frações de colágeno com diferentes graus de solubilidade. A primeira dessas fraçōes é extraída por soluçōes neutras e parece incluir as moléculas de colágeno ainda não polimerizadas e as já polimerizadas até o estado de microfibras. Trata-se do neocolágeno, sendo o primeiro a mostrar radioatividade quando se administra ao animal um precursor marcado como prolina-H3 ou glicina-H3. O colágeno solúvel em soluçōes ácidas é obtido após extração do restante do tecido com solução de citrato de sódio pH3. A Gltima fração denominada colágeno insolúvel contém o colágeno que restou após as duas primeiras extraçóes, e só pode ser dissolvida se the aplicarmos processos muito drásticos. Como a radioatividade administrada sob a forma de precursores de colágenos aparece primeiro na fração solúvel em soluções neutras, em seguida na fração soluvel em acido, e por altimo na fração insolúvel, admite-se que as três frações representem estágios sucessivos de agregação e insolubilização do colágeno (JUNQUEIRA E CARNEIRO, 1979). 
- colágeno é sintetizado por diversos tipos celulares, como fibroblasto, osteoblasto, odontoblasto, condrócito e célula muscular lisa, da seguinte maneira: (FIGURA 3).

1-De acordo com a codificação no RNA mensageiro, os polirribossomos ligados ao retículo endoplasmatico sintetizam cadeias polipeptidicas, que crescem para $\circ$ interior das cisternas.

2-⿱亠̀ medida que essas cadeias se formam, ocorre a hidroxilação da prolina e da lisina. A hidroxipolina e hidroxilisina não são incorporadas nas cadeias polipeptidicas do colágeno pelos mecanismos usuais de sintese protéica. Se hidroxipolina $14 \mathrm{C}$ for administrada a um rato, nenhuma radioatividade aparece no colágeno sintetizado. Ao contrário, a hidroxipolina do colágeno ficará marcada se administrarmos 14Cprolina. Assim, a prolina é precursora dos residuos de hidroxiprolina do colágeno, enquanto que a hidroxiprolina exógena não o é. A prolina é transformada em hidroxiprolina por uma enzima chamada procolágeno hidroxilase. oxigênio molecular, Ion ferroso, e cetoglutarato são necessários para a sua atividade. Um agente redutor, tal como o ácido ascórbico é também necessário para a reação de hidroxilação (LUBERT, 1988).

Esta reação é altamente especifica. A prolina sob a forma livre não é substrato. Antes, a hidroxilação realiza-se em sitios especificos nas cadeias polipeptidicas. Uma prolina somente pode ser hidroxilada se estiver situada do lado aminado de um residuo de glicina. Devem haver restrições adicionais, 
pois nem todas prolinas nesta posição são hidroxiladas. A conversão de lisina em hidroxilisina é catalisada por uma enzima diferente.

3-Quando a hidroxilisina se forma começa sua glicosilação. Todas as cadeias colágenas (alfa) tem hidratos de carbono sobre a forma de glicose ou de glicosilgalactose, ligadas à hidroxilisina. As enzimas responsáveis pela glicosilação parecem estar associadas ao retículo endoplasmático granular.

4-Cada cadeia alfa é sintetizada contém dois polipeptídios em registro, um em cada extremidade. Estes peptidios determinam o alinhamento das cadeias protéicas em grupos de três, facilitando a combinação dessas cadeias para formar uma molécula de procolágeno, que é precursora, porém maior que a do colágeno. outra função dos peptídios em registro é impedir a formação de fibras colágenas no interior das células, pois as moléculas de procolágeno não se agregam, como acontece com a do colágeno. Os peptídios em registro são separados da cadeia alfa, no meio extracelular, pela ação da enzima procolágeno peptidase que parece ser produzida pelas mesmas células que sintetizam colígeno.

- colágeno é formado por grupos de fibrilas polimerizadas, para formar fihras, estas em fibras, e por último unindo as fibras para formar feixes colágenos, as fibras quando aquecidas a $70^{\circ} \mathrm{C}$ encurtam a um terço do comprimento original. $\grave{A}$ temperaturas de $80^{\circ} \mathrm{C}$ ou mais, 0 colágeno é 
convertido em gelatina (BERK, 1976; CHEFTEL \& CHEFTEL, 1976; FRIBERG, 1976; CANHOS \& DIAS, 1982).

As ligações cruzadas do colágeno são originadas dos grupos $-\mathrm{NH}_{2}$ residuos de lisina (nas regiões terminais não hélicoidais) que são oxidativamente desaminadas por enzimas cobre dependentes como a lisiloxidase. o aldeldo resultante forma uma ligação com outro grupo $-\mathrm{NH}_{2}$ da lisina e hidroxilisina presentes nos domínios helicoidais ou não, gerando novas ligaçōes diferentes intra e extramoleculares. A ligação intramolecular foi identificada como alfa, beta-aldol insaturada que liga as três cadeias alfa na molécula (SHIMOKOMAKI, 1989).

As ligações intermoleculares são termolábeis do tipo aldimina dehidrohidroxi-lisino-norleucina e termo-estável hidroxi-lisino-5-ceto-norleucina. O grupo-CHO derivado do resíduo da região terminaj. e o grupo $-\mathrm{NH}_{2}$ do residuo hidroxilisina na região da tripla hélice $(28 \mathrm{~nm}$ da $\mathrm{N}-$ ou Cterminal) da molécula adjacente estão envolvidas nas ligações cruzadas intermoleculares (ASGHAR \& YATES, 1979; ASGHAR et al., 1982, 1985).

HENRICKSON et al., (1982) discutiram extensivamente sobre a composição e a estrutura do colágeno. Essas são influenciadas por variáveis como a espécie, a raça, o sexo e o estado nutricional do animal. 


\subsection{2 - Reticulina}

Alguns pesquisadores consideram a reticulina como sendo forma de colágeno tipo III. Está presente durante o desenvolvimento embrionário e com o crescimento são superadas numericamente pelo colágeno. As fibras são finas e ramificadas e freqüentemente estão intimamente ligadas ao endomisio do tecido muscular. A reticulina é semelhante ao colágeno em alguns aspectos, porem não tem a propriedade de tornar-se gelatina com o aquecimento (FRIBERG, 1976; CANHOS \& DIAS, 1982).

\subsection{3 - Elastina}

A elastina é a proteŕna menos abundante do tecido conjuntivo e contém dois aminoácidos pouco comuns, como a desmosina e a isodesmosina, os quais estão envolvidos na ligação cruzada de cadeias peptídicas, responsáveis pelas propriedades elásticas (BERK, 1976; CHEFTEL, 1976; LAWRIE, 1981; CANHOS, 1982; LAWRIE, 1985). Năo é decomposta pelo calor e contém pouca hidroxiprolina. o conteúdo em valina é muito maior. E muito resistente a ácidos e alcalis devido ao pequeno numero de cadeias ionicamente carregadas da molécula (BAILEY, 1983; LAWRIE, 1985). Sua fibras são facilmente esticadas, ocorrendo ponto de quebra aproximadamente a 150 de seu comprimento original, e voltam ao seu tamanho original apos serem esticadas. E extremamente insoluvel devido ao alto teor em aminoácidos não polares e j̀ ligações que agregam quatro cadeias vizinhas de elastina através de ligaçōes 
intramoleculares de unidades de lisina. altamente resistente às enzimas digestivas (FRIBERG, 1976; CANHOS \& DIAS, 1982). 


\section{3 - Pele como fonte de colágeno}

A pele animal é um depósito de colágeno e por esse motivo é utilizada como matéria-prima comercial para a sua produção (MONTANA et al.1970). A camada da derme, rica em colágeno, apresenta vasos sangüíneos e músculos (Bowes \& RAISTRICK, 1968), com quantidades pequena de elastina, reticulina, fibroblasto e algumas proteínas globulares (COOPER \& JOJMSON, 1958; COOPER et al., 1967; HUMPHREY et al., 1956, 1957; MELLON et al., 1960).

TAJIMA \& NAGAI (1980) demonstraram que a distribuição do colágeno nas diferentes camadas da pele, varia significativamente.

Segundo NICOLAIDES et al. (1968) e WILKINSON (1969), a pele é composta basicamente por água e colágeno contendo também glicosaminoglicanas, (MEYER et al. 1957, SCHILLER 1966, CIFONELLI \& RODEN, 1968; KOFOFD \& BOZZINI 1969). A fração lipidica consiste de triglicérides, ceras, esterol, ésteres e ácidos graxos. (Quadro 2) 
Quadro 2 - Composição da pele Bovina:

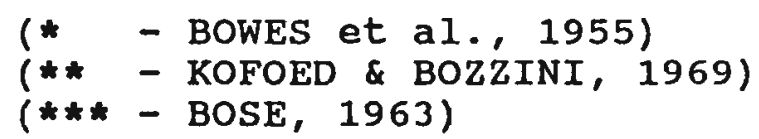

1 - Água* - 60-65\%

2- Proteina* 30-35\%

a) Globular $0,5-0,7 \%$

b) Glicoproteína $0,5-0,7 \%$

c) Colágeno $80-95 \%$

Solúvel em sal neutro $0,03-0,68$

Ácido solúvel $0,05-2,6 \%$

3- Glicosaminoglicanas * $\quad 0,345 \%$

a) Ácido hialurônico $525 \mathrm{mg} / \mathrm{g}$ (pele seca)

b) Sulfato de Dermatan $205 \mathrm{mg} / \mathrm{g}$ "

c) Heparina $71 \mathrm{mg} / \mathrm{g}$ "

d) 4 Condroitin sulfato $69 \mathrm{mg} / \mathrm{g}$ "

e) 6 Condroitin Sulfato $68 \mathrm{mg} / \mathrm{g}$

f) Heparitina $58 \mathrm{mg} / \mathrm{g}$ "

4- Ácidos nucléicos $1 \%$ **

a) Ácido ribonucléico 0,8\%

b) Ácido desoxiribonucléico 0,2\% 


\section{4 - Colágeno para fins industriais}

A pele tratada é utilizada para a indústria de couro, e "in natura" para a produção de alimentos.

Na produção de couro, o tecido não pode apresentar-se danificado, o que reduz muito sua utilização, aliado ao fato de ser este um processo de alto custo. Sendo assim a maior parte deste material destina-se ao uso alimenticio. Encontramos na literatura varias técnicas industriais descrevendo métodos para aproveitamento da pele com fins alimenticios, (ELIAS et al., 1970; WHITMORE et al., 1970; KOMANOWSKY et al., 1974).

A gelatina proveniente do colágeno é usada em três areas quais sejam: alimenticia (GOTLHÖFFER, 1945; IDSON \& BRASWELL, 1957; BATTISTA, 1975; CURTS 1977; BADWELL, 1977), fotografica (COX, 1972; ROSE, 1977) e na área farmacêtica (CHVAPIL et al., 1973; WOOD, 1977; BHANDARI, 1978). Segundo IDSON \& BRASWELL (1957), 65\% destina-se ao uso alimentício, 20\% para filmes fotográficos e 15ํㅗㅁ na área farmacêtica.

o uso de colágeno como gelatina apresenta implicaçōes nutricionais. Tendão tratado com solução de óxido de cálcio por tempo prolongado, facilita a solubilizaçāo do colágeno, levando a desaminação dos aminoacidos essenciais básicos como lisina, arginina e histidina, ou decomposição dos hidroxiaminoácidos como a treonina, (THEIS \& JACOBY, 1941; HIGHBERGER \& STECKER, 1941). Provavelmente este é o motivo pelo qual estes aminoácidos são limitantes em relação ao valor nutricional da gelatina (CHAPMAN, 1959; RAMA-RAO et al., 1964). 
- tratamento alcalino induz outros tipos de alterações indesejáveis à proteína. Nestes incluem racemização dos aminoácidos (MASTER \& FRIEDMAN, 1980; SMITH, 1980) e formação de lisinoalanina (FRIEDMAN, 1978). De acordo com FRIEDMAN et. al. (1981) ocorre reação de beta-eliminação da serina, treonina e cisteina. Este tipo de tratamento também implica em alterações nutricionais.

As propriedades funcionais da proteĺna são importantes frente às caracteristicas organolépticas dos produtos alimenticios processados. A digestibilidade, valor biológico e a proporção de aminoácidos essenciais determinam o valor nutricional da proteina. Estas variáveis afetam a eficiencia do potencial de utilização da proteína na alimentação humana.

o colágeno quando utilizado in-natura não apresenta alteração de suas estruturas protéicas. Por outro lado, quando submetido à processos industriais pode ocorrer alteração nestas estruturas, levando à diminuição do valor nutricional e alteraçăo nas suas principais características organolépticas e propriedades funcionais.

Estudos feitos por BENDER \& ZIA (1976) demonstraram que alimento de baixa qualidade contém 23,6\% de tecido conjuntivo e uma utilização protéica líquida (NPU) de 69, enquanto a carne em lata contendo $2,8 \%$ de colágeno tem NPU de 82. O NPU em carnes geralmente varia de 62 a 78 e a média é de 74. O NPU da carne decresce com o cozimento principalmente devido a perda de metionina. 
No colageno os aminoácidos essenciais, metionina, lisina e treonina são limitantes enquanto o triptofano está ausente. A adição de colágeno nos produtos alimentícios diminui - valor nutricional dos mesmos. Por este motivo, orgãos oficiais internacionais procuram estabelecer valores minimos de coeficiente de eficácia protéica. (CEP) e estabelecer a quantidade de aminoácidos essenciais nos alimentos. Estabeleceu-se CEP de 2,5 e um conteludo mínimo de aminoácidos essenciais de $32 \%$ (LEE et al, 1978).

Trabalhos publicados por ASHLEY \& FISHER (1966), demonstraram que frangos alimentados com $10 \%$ de gelatina, acrescida de $3 \%$ de caseina ganharam igual peso em relação aos frangos alimentados com $13 \%$ de proteína de soja acrescidos de $0,2 \%$ de metionina.

ERBRADABLER et al., (1970), encontraram ganho de peso em ratos machos, incorporando na alimentação níveis superiores a 58 de colágeno na dieta. A adição de colágeno na dieta não necessariamente diminui o valor nutritivo, porém esse não deve ser superior a $28,5 \%$.

ERBRADABLER et al.. (1970), demonstrou que em dieta contendo $30 \%$ de colágeno associada a outras proteinas, utilizando o Indice NPU, verificaram que houve crescimento dos animais embora a quantidade de colágeno na carcaça não tenha sido alterada em função da dieta. Ainda em relação a ingestão de colágeno, ANITA \& FAVRIANSSANM, (1985), verificaram que a inibição da secreção gástrica não afeta a digestibilidade em aves. 
Com relação à excreção urinária da prolina e hidroxiprolina em dietas ricas em colágeno RIGNITTER et al. (1978), estudaram a relação do colágeno-peptidase e hidroxiprolina plasmatica excretada por individuos saudáveis e portadores de doenças consulptivas quando utilizada dietas com e sem colágeno. Verificou-se que a atividade do colágenopeptidase independe da dieta e o metabolismo não influencia no nivel de hidroxiprolina em pessoas saudáveis e doentes.

PILANCHERY et al. (1982), determinaram niveis urinários de peptidios de hidroxiprolina dialisáveis, hidroxiprolina livre e a relação hidroxiprolina não hidrolisada. Utilizou-se dietas com diferentes quantidades de hidroxiprolina. Verificou que a excreção urinária total e os niveis de peptidios de hidroxiprolina dialisada variavam com quaisquer teores de colsgene da dieta, enquanto que a quantidade de hidroxiprolina livre variava somente em dietas com alto teor de colágeno.

BODWELL (1987), através de trabalhos desenvolvidos da University of Gueph, suspeita que a prolina e hidroxiprolina façam parte da necessidade essencial dos aminoácidos durante o crescimento animal.

JUERGENS \& DOLIF, (1972) e WATTS et al., (1965), demonstraram que embora a prolina seja um aminoácido não essencial, sua produção endógena é aparentemente limitada. Retardo no crescimento de ratos. que se alimentaram somente de aminoacidos essenciais, foi bastante atenuado com o acréscimo de prolina. Resultados semelhantes foram descritos por WOMACK \& 
ROSE, (1947) e BREUER et al., (1964). JUERGENS \& DOLIF, (1968), baseados em experiências com alimentação parenteral no homem, indicam que a prolina aumenta, indubitavelmente, o equilibrio do nitrogênio quando acrescida a aminoácidos essenciais.

Diversas vezes foram encontradas altas concentrações de prolina plasmatica, em estudos de valores basais de aminoácidos no plasma, durante os primeiros dias de vida. Esses resultados levam à conclusão de que a administração exógena de prolina é aconselhável quando na dose certa. Bạseada na resposta a provas de carga endovenosa, a dose recomendada foi estabelecida em $50 \mathrm{mg} / \mathrm{kg}$ de peso corpóreo. E importante lembrar que através de vias metabólicas a arginina pode se converter em prolina conforme demonstrado na figura 4 (GHADIMI \& PECORA, 1964).

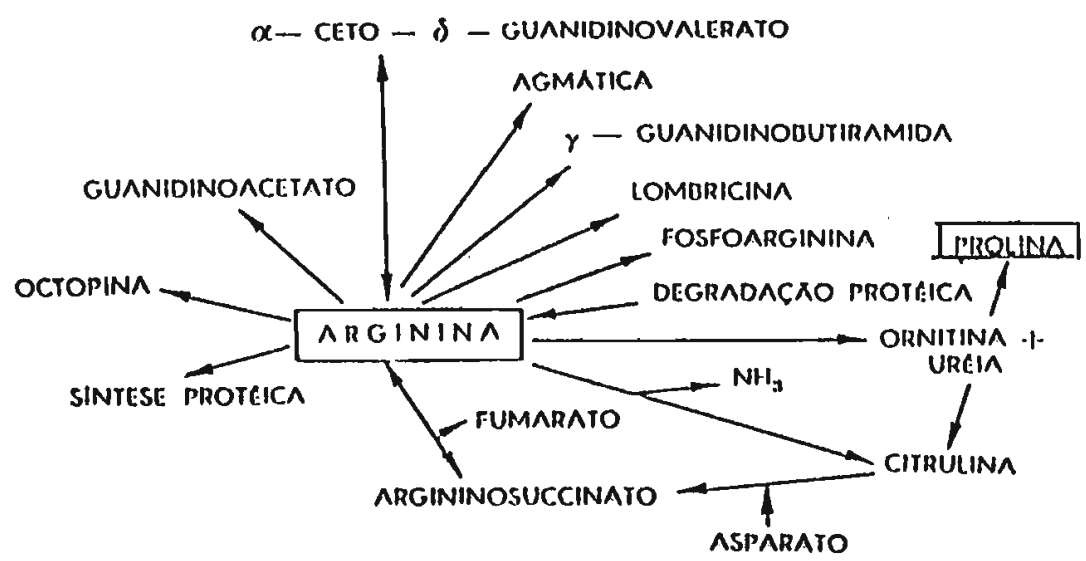

FIGURA 4- VIAS METABOLICAS DA ARGININA ( GHADIMI 1977) 


\section{Aminoácidos essenciais}

A importância do provimento de quantidades adequadas (individual) de aminoacidos é atriburda à sequêencia especrfica das sub unidades necessarias na constituição da proteína. A deficiência de apenas um aminoácido interrompe a seqüência e impede a síntese protéica (GHADINI, 1977)

A essencialidade é a necessidade quantitativa dos aminoacidos indispensáveis ao organismo. Estudos em humanos de necessidade de aminoácidos levaram ROSE et al., (1955) a concluir que inicialmente os seguintes aminoácidos são essenciais para a espécie humana: valina, triptofano, treonina, fenilalanina, metionina, lisina, leucina e isoleucina.

Histidina é essencial para crianças e adultos com alterações renais crônicas, e não é considerada essencial para adultos sadios (KOPPLE \& SWENDSEID, 1975).

GAULL et al., (1977), demostraram que em recém nascidos a necessidade endógeno de cisteína é essencial até que sejam suficientemente maturos para produzir a cistationase hepatica, necessária para a sintese de cisteina a partir da metionina.

RUDMAN (1983), sugeriu também que em pacientes adultos com patologia de fIgado, tirosina e a cisteína tornamse condicionalmente essenciais desde que o figado tenha perdido sua habilidade de produzir esses aminoácidos através de seus precursores. 
MITCHELL \& BLOCK (1946), estudaram a alta correlação entre o valor biológico experimental determinado para dieta protéica e a porcentagem dos aminoácidos essenciais na proteina. Os autores concluiram que os resultados de seus estudos não podem ser conciliados com o conceito de que a qualidade da proteína é linearmente relacionada à quantidade de aminoácidos reduzidos abaixo dos niveis adequados e devem ser determinados similarmente pela porcentagem de déficit dos aminoácidos limitantes na dieta. Neste estudo, os autores consideram que, o efeito da carência do aminoácido dépende de qual aminoácido está deficiente na dieta. Mistura de aminoácidos como histidina e lisina não se mostrou tão limitante quanto aquela contendo metionina e cistina. Segundo KINO \& OKUMURA $(1986 \mathrm{a}, \mathrm{b})$, os métodos para calcular o valor nutricional da proteína devem levar em consideração a especificidade nutricional de cada aminoácido.

A glutamina, aminoácido não essencial, tem sido recentemente muito estudada devido sua importância fisiológica. A glutamina aparece como o anico aminoácido utilizado preferencialmente como combustivel respiratório para a rápida proliferação de células, tais como eritrócitos e linfócitos, é regulador do balanço ácido-básico na produção de amonia urinária e carreador de nitrogênio entre os tecidos. E importante precursor do ácido nucléico, nucleotídeos, aminoaçucares e proteínas. Evidências sugerem que a glutamina pode tornar-se condicionalmente essencial, em casos patológicos críticos. Em condições de "estresse" as necessidades orgânicas de glutamina parecem exceder as quantidades produzidas deste 
aminoácido. A suplementação de glutamina enteral ou parenteral pode melhorar o quadro patológico, diminuindo o tempo de estadia hospitalar (LACY \& WILMORE, 1990).

Verificou-se nos casos de desbalanço de aminoácidos em porcos, que a ingestão elevada de metionina e triptofano não diminui a eficiência da utilização do alimento, sugerindo que esses aminoácidos não antagonizam outros aminoácidos, mas ao invés disto, causam desbalanço, onde o peso ganho é reduzido como resultado de uma diminuição da ingestão do alimento.

Treonina acima de $4 \%$ na dieta não altera o peso ganho ou o consumo da ração. Leucina parece ter influência no peso ganho ou consumo de alimento, somente em concentrações acima de 6\%, além de que excesso de leucina causa drástico decréscimo nos nIveis plasmáticos de isoleucina e valina (KINO \& OKUMURA, $1986 b)$.

\section{$\underline{2.5}$ - Caracteristicas da Pele}

\section{$\underline{2.5 .1}$ - Estrutura de Pele}

A pele, limite anatomico do organismo animal, sem a qual a vida não existiria, constitui uma barreira semi impermeável e é o principal orgão de comunicação com o meio externo reapresenta aproximadamente $6 \%$ do peso corporal e contem $30 \%$ do sangue circulante (VIGLIOGLIA \& RUBIN, 1989). 


\subsection{2 - Funções da Pele}

As principais funções são: semi permeabilidade, resistência, plasticidade, elasticidade e reserva de energia, controle de temperatura de $\mathrm{pH}$, de perda de água, de penetração da radiação UV, flora microbiana, (VIGLIoGLIA \& RUBIN, 1989).

\section{$\underline{2.5 .3}$ - Composição da Pele}

Composta por três camadas:

Epiderme, derme e hipoderme (fig. 5) 


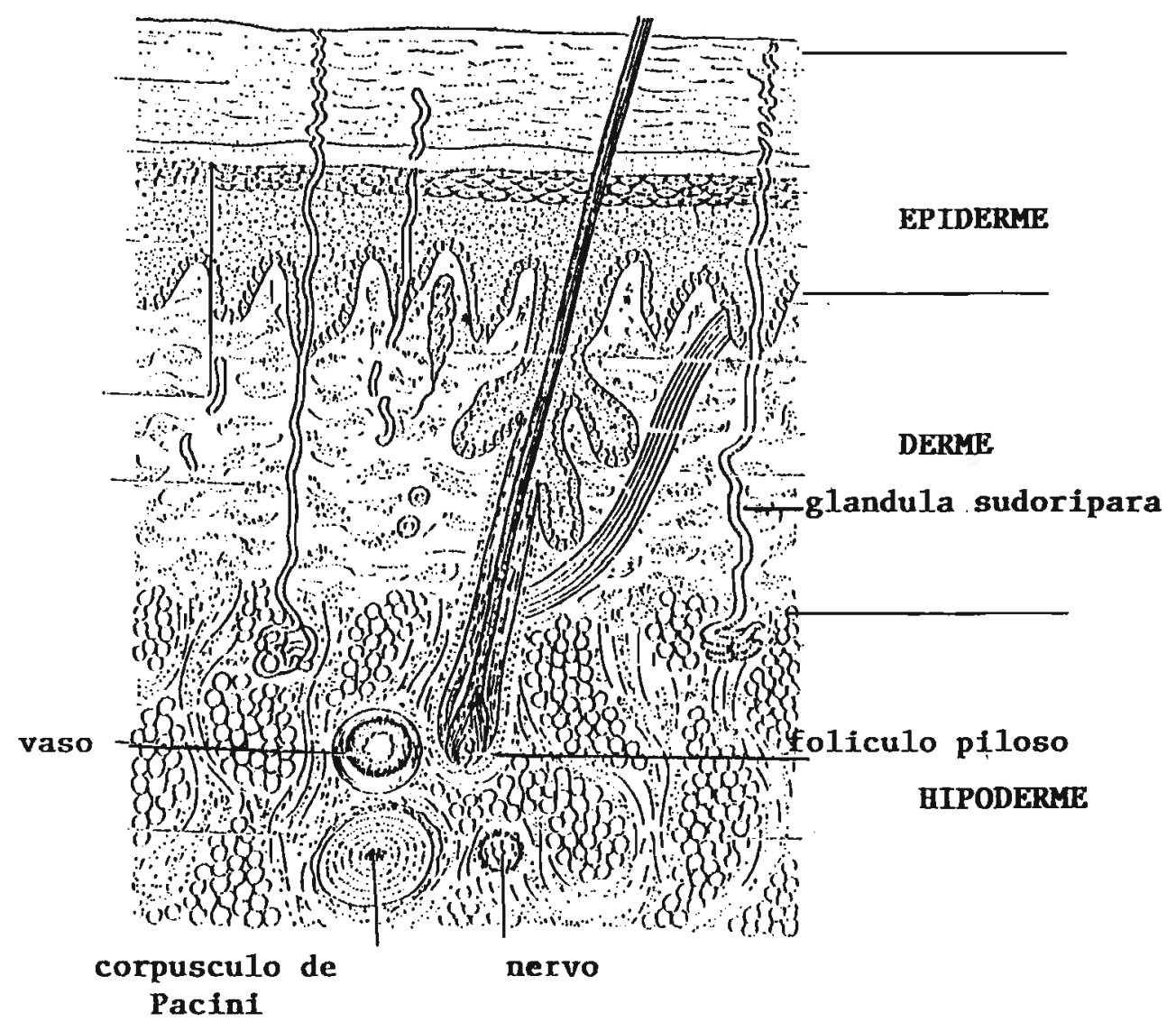

FIGURA 5 - CORTE ESQUEMATICO DE PELE NORMAL (QUIROGA \& GULLLOT 1973 ) 


\section{Epiderme}

Epiderme formada pelas camadas basal, malpighi, espinhosa, granulosa e cornea e apresenta uma espessura de 0.05

a $0.2 \mathrm{~mm}$. E um epitelio versatil cujas células se multiplicam e diferenciam e renovam periodicamente. Esta diferenciação especializa-se em cumprir determinadas funções fundamentalmente de proteção e semi-permeabilidade nela se encontram os melanócitos responsáveis pela coloração da pele (QUIROGA \& GUILLOT, 1973).

\section{Derme}

A Derme formada por tecido conjuntivo caracteriza-se por possuir grande variedade de tipos celulares e pela abundáncia e variedade do material intercelular. A função do tecido conjuntivo é, como seu próprio nome indica, a de unir as células nos tecidos e estes nos órgãos exercendo importantes funções na nutrição destas células, armazenamento de materiais e é dotado de uma certa reatividade que constitui uma defesa do organismo contra agentes estranhos (QUIROGA \& GUILLOT, 1973).

A Derme é constituida fundamentalmente por células de vários tipos, algumas das quais produzem as fibras colagenas. Além das células e fibras existe no tecido conjuntivo uma substância fundamental amorfa de contituição química complexa (QUIROGA \& GUILLOT, 1973). 


\section{Células}

Dentre as inúmeras células da derme - histiócitos, plasmócitos, mastócitos, células adiposas, etc., merecem menção especial os fibroblastos e as células mesenquimais indiferenciadas.

Os fibroblastos são as célulias mais numerosas e mais importantes, devido à sua propriedade de produzir a parte fibrosa e provavelmente também a parte amorfa deste tecido. Trata-se de uma célula em geral fusiforme, algumas vezes possuindo prolongamentos ramificados, com um núcleo ovóide cuja cromatina apresenta-se finamente granulosa. No entanto, a morfologia dos fibroblastos varia, de uma célula em atividade ou de uma célula dita em repouso. Os fibroblastos que estão produzindo colágeno, possuem maior volume, núcleo com cromatina mais delicada e citoplasma basófilo. Ao contrário, os fibroblastos maduros, ou fibrócitos, são células menores, com núcleos mais compactos e citoplasma acidófilo (QUIROGA \& GUILLOT, 1973) .

Embora considerados como células fixas, os fibroblastos são capazes de se movimentar nos cultivos de tecidos e nas feridas em cicatrização. Nesses casos, a movimentação do fibroblasto pode se dar por uma espécie de deslizamento, o que é de grande importância no preenchimento de áreas destruidas por processos patológicos (WELSS \& KLEIN, 1969). 


\section{Fibras}

os elementos intercelulares figurados do tecido conjuntivo são classicamente conhecidos como sendo as fibras colágenas, fibras reticulares e fibras elásticas, embora se admita a existência de outros tipos de fibras (HARKNESS, 1958).

Fibras colágenas - Estas são estruturas de grande resistência à tensão e ocorrem em grande quantidade na pele, fascias, ossos e cartilagem e em grande percentagem, mas de modo estruturalmente mais organizado, nos tendões (WIDDOWSON, 1968) .

Ao exame microscópico a fresco mostram ser constituidas de fibras. Após coloração têm aspecto ondulado quando isoladas e formando feixes quando em maior quantidade, tendo afinidade tintorial pela eosina e outros corantes ácidos.

Fibras reticulares - Ao microscópio aparecem finas e ramificadas, tendo algumas diferenças tintoriais em relação às fibras colágenas. Impregnam-se pela prata e são P.A.S. positivas (isto é, coram-se em vermelho quando submetidas à técnica de Reagente de Schiff). Ao microscópio eletrônico mostram possuir fibrilas com a mesma periocidade axial que as fibras colágenas. São portanto muito semelhantes às fibras colágenas recém-produzidas, também chamadas de fibras précolágenas. Mas as fibras reticulares são diferentes das précolágenas também denominada procolageno pois ao se formarem elas se associam a lípides e glucideos que além de lhes conferir caracteristicas tintoriais próprias ainda as impede de se unirem entre si, como acontece com as fibrilas colágenas a 
fim de formarem as fibras colágenas (JUNQUEIRA \& CARNEIRO, 1977) .

$$
\text { Fibras elásticas - São finas, refringentes e formam }
$$
uma rede frouxa. Estas coram-se seletivamente pela orceina, pela fucsina-aldeido de Gomori e por outros corantes. Ao microscópio ótico cada fibra aparẹce homogênea, não sendo formada de fibras mais finas, como é o caso das fibras colágenas (PARTRIGE, 1965).

As propriedades físicas das fibras elásticas são complementares das do colágeno. São fibras dotadas de alta elasticidade, porém pouco resistentes às trações.

As fibras elásticas são constituidas por elastina. Esta é uma proteína formada ao menos por dois componentes, denominados alfa e beta. A elastina alfa tem um peso molecular de 60000 a 84000 e a beta tem um peso molecular de 6000 (HARKNESS \& HARKNESS, 1961).

\section{6 - Metabolismo protéico}

\section{6 .1 - Revisão}

Entre 1866 e 1940, aproximadamente, levantou-se a grande polêmica quanto ao fato de as proteínas, que constituem parte de uma estrutura viva, serem metabólicamente inativas em condições normais ou sujeitas a alterações anabólicas e catabólicas (FOLIN, 1986; RUBNER; 1910; BORSOOK, 1935). Com a aplicação a problemas do metabolismo animal, das técnicas isotópicas de marcação, desenvolveu-se o conceito, universalmente aceito, do "metabolismo nitrogenado contínuo". 
Segundo estudo clássico de Schoenheimer et al.(1940), quando se administram a animais aminoácidos ou amônia marcados com ${ }^{15} \mathrm{~N}$, grande parte dos mesmos incorpora-se nas proteínas tissulares.

SCHOENHETMER \& RITTENBERG (1940) demonstraram que o nitrogênio isotópico administrado em forma de aminoácidos se incorporava rapidamente as proteínas do plasma, mucosa intestinal, fígado, baço e medula óssea, embora osso, pele e músculo retivessem apenas pequenas quantidades de nitrogênio isotópico por unidade de peso tissular. Essas observações conduziram ao conceito de que quase todas as protelnas no corpo estivessem em permanente fluxo, sendo continuamente sintetizadas e degradadas e que este fluxo fosse, na verdade, uma das principais características do tecido vivo.

Estudos subsequentes utilizando outros indicadores como isótopos radioativos de carbono, hidrogênio e enxofre confirmaram as observações de Schenheimer (1940), reafirmando, igualmente, acentuadas diferenças entre vários tecidos quanto ao consumo de aminoácidos marcados (SWICK, 1957; SCHIMKE, 1964). O termo "turnover", que se difundiu, significa a substituição de uma quantidade de proteína degradada pela mesma quantidade da mesma proteína, recém-sintetizada de seus precursores metabólicos. o "turnover" ou renovação protéica poderá ocorrer através de três diferentes processos. Primeiramente, a proteína poderá tornar-se parte de uma estrutura com período de vida fixo (LIPKIN, 1965).

o segundo tipo de "turnover" pode ser exemplificado por algumas das proteinas soluveis da célula ou pelas proteinas de diversos IIquidos corpóreos, que não constituem parte da 
estrutura organizada e são degradadas ao acaso, em velocidade constante (SCHIMKE, 1970).

o terceiro tipo de "turnover" protéico corresponde ao exemplo das proteínas secretadas de uma célula e desdobradas em outra parte do corpo (SCHIMKE, 1970).

\subsection{3 - Requlação do anabolismo proteíco}

A regulação da síntese protéica em uma célula ou tecido poderá resultar em alteração na quantidade de proteína sintetizada na unidade de tempo ou produção qualitativa de proteínas especificas. A regulação qualitativa é exercida quando uma espécie de proteína surge ou desaparece em uma célula.

A regulação quantitativa da síntese protéica pode ser realizada por dois métodos principais: pela alteração da quantidade de células em um tecido que sintetize uma proteína especifica ou pela regulação da quantidade de proteína que pode ser formada por cada célula.

- segundo mecanismo para a regulação da síntese protéica acarreta alterações uniformes na velocidade da síntese em todas as células de um tecido, sendo considerado o principal método para regulação em quase todos os estados. A síntese de cadeias peptídicas é um processo complexo; a regulação pode ser prevista em muitas etapas antes da liberação de um produto final. As etapas de limitação de velocidade na síntese da proteína celular poderão incluir (a) o suprimento de aminoácidos ou mesmo de um aminoácido; (b) a concentração de 
aminoacil-tRNA; (c) alteração nos diversos fatores de tradução; (d) disponibilidade de ligações de fosfato de grande energia; (e) variações na quantidade e velocidade de degradação de mRNA e (f) disponibilidade de ribossomos.

\subsection{4 - Regulação da deqradação protéica}

- desdobramento protéico abrange um "processo de envelhecimento" ou uma "degradação cinética" de cada proteína. A hemácia representa um exemplo do processo de envelhecimento, pelo qual, após um período de vida especifico, ocorre alguma alteração na estrutura, permitindo degradação da célula. o mecanismo que controla o período de vida de diversas células ainda não foi esclarecido, mas parece ser típico em diferentes tipos de células. o período de vida da célula da mucosa intestinal depende da velocidade da mitose e liberação da cripta intestinal, movimento pela vilosidade acima e liberação na luz intestinal (MEIKLEHAM et al., 1951). Na hemácia, o período de vida pode ser controlado pela diminuição progressiva de certas atividades enzimáticas, principalmente da desidrogenase glicose 6-fosfato (KOCHAKIAN et al., 1948). Outro exemplo do processo de envelhecimento seria a secreção de enzimas digestivas no trato digestivo. Assim, o desdobramento dessas proteínas depende da velocidade de secreção no trato instestinal. A degradação pelo processo de envelhecimento não é ao acaso e não está em conformidade com a cinética de primeira ordem. A regulação da degradação protéica durante o processo de envelhecimento, portanto, representa alteração no período de vida das células ou na velocidade de secreção de proteínas degradadas em outro local. 
o conceito de degradação cinética difere do conceito de envelhecimento, uma vez que envolve cinética de primeira ordem, proporcional à concentração (SCHIMKE, 1970), significando velocidade ao acaso. Embora outras interpretações sejam viáveis, essa cinética indica que, uma vez sintetizada uma molécula de uma determinada espécie de proteína, sua degradação ocorrerá ao acaso. Isso fói observado principalmente em proteínas extra e intracelulares assim como em organelas (SCHIMKER, 1970).

Influência de diversos estados fisiológicos nas velocidades de anabolismo e catabolismo em vários tecidos

As primeiras tentativas para se compreender o metabolismo protéico basearam-se no conceito no balanço do nitrogênio (B), que pode ser definido pela seguinte equação (ALLISON, 1955):

$$
\mathrm{B}=1-(\mathrm{U}+\mathrm{F}+\mathrm{S})
$$

em que $B$ é a diferença entre o consumo de nitrogênio (1) e excreção do nitrogênio na urina (U), fezes (F) e pele (S). Assim, um valor positivo para B representa retenção de nitrogênio; um valor zero, equilíbrio de nitrogênio e um negativo, perda de nitrogênio. Esse conceito pode ser ilustrado segundo a fig. 6 onde o consumo protéico recomendado pela FAO/OMS (1965), representando $70 \mathrm{~g}$ de proteína mista, de utilização protéica final, de 70. Essa proteína faz parte de uma dieta que supre um mínimo de $2500 \mathrm{Cal}$, além de vitamina e nutrientes minerais. Nessas condições, o equivalente a $10 \mathrm{~g}$ de proteína será perdido nas fezes, $55 \mathrm{~g}$ na urina e $5 \mathrm{~g}$ da pele e gases, contendo nitrogênio gasoso. Calcula-se, também, que 
cerca de $50 \mathrm{~g}$ de uma proteína dietética sejam utilizados para atender à chamada perda obrigatória de nitrogênio ou à quantidade de proteína corpórea que deve ser diariamente substituía a partir de fontes dietéticas. Young e scrimshaw (1968), por outro lado calcularam a perda obrigatória de nitrogênio em $30 \mathrm{~g}$ de proteína, diariamente, em um homem de $70 \mathrm{Kg}$. A grande diferença entre essas duas estimativas indica a possibilidade de erros relacionados com os cálculos de balanço de nitrogênio.

$70 \mathrm{gm}$

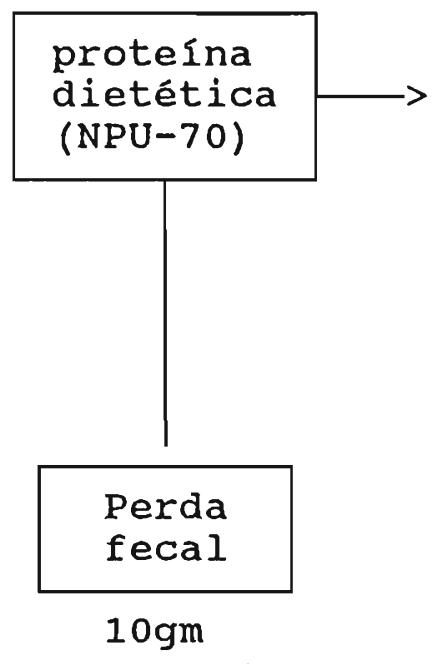

proteina dietética (NPU-70)

FIGURA 6 - Metabolismo proteĺco diário GHADIMI， 1975.
$12,5 \mathrm{gm}$

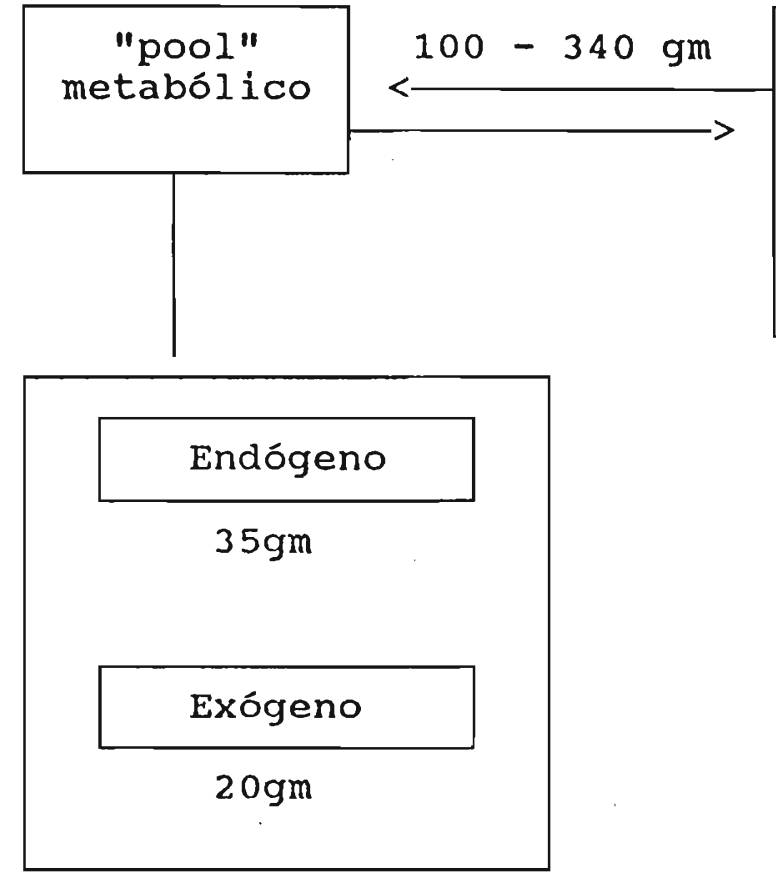

$13300 \mathrm{gm}$

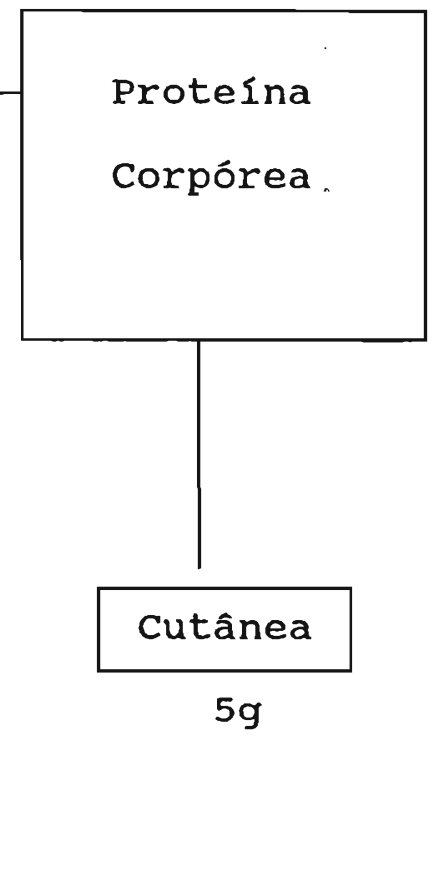


As técnicas para a determinação do "turnover" protéico em todo o corpo foram analisadas por Waterlow (1969), indicando grande variação nestas determinações. Essas técnicas abrangem o uso de aminoácidos marcados, administrados como infusão contínua ou única. Através desses métodos, calcula-se que o "turnover" protéico de todo o corpo varie entre 100 e $340 \mathrm{~g}$ de proteína, diariamente, em um homem de $70 \mathrm{Kg}$, encontrando-se a maior parte dos valores entre 285 e $340 \mathrm{~g}$. Não obstante essa acentuada variação, é obvio que a sintese protéica diária excede de 2 a 6 vezes às necessidades protéicas computadas. Essas observações confirmam a grande reutilização, no corpo, de aminoácidos liberados do desdobramento tissular. 0 modelo cinético apresentado nos trabalhos clássicos de sprinson et al. (1949) indicaram que a proteína corpórea está em equilíbrio com um "pool" metabólico de aminoácidos; a proteína dietética é acrescida a esse "pool" metabólico. Mais ainda: os aminoácidos perdem-se desse "pool" através do grupo de compostos nitrogenados, excretados na urina. Desses exemplos calcula-se que o "pool" de aminoácidos livres contenha aproximadamente o equivalente a $12,5 \mathrm{~g}$ de proteína (TSCHUDY et al., 1959), sendo distribuído entre os diversos tecidos do corpo. A partir de análises em cadáveres, calcula-se que o corpo humano contenha aproximadamente $19 \%$ de proteína ou $13,3 \mathrm{Kg}$ de proteína em um homem de 70Kg (FORBES et al., 1953). Assim o "pool" metabólico de aminoácidos representa apenas cerca de $0,1 \%$ da proteína corpórea total. Além disso, apenas de 1 a 2,6\% da proteína corpórea total é reconstituída diariamente no adulto. Poderíamos pensar que, a partir do "turnover" relativamente lento da proteína corpórea total, o adulto 
pudesse compensar as instabilidades no consumo dietético protéico com alterações de importância relativamente pequena na composição da proteína corpórea total. Entretanto, conforme discutido abaixo, cada tecido ou populações celulares variam muito em suas velocidades de "turnover" protéico, podendo ser muito influenciados pela economia protêica do hospedeiro. São Iimitados os dados sobre o "turnover" de cada proteína ou misturas de proteínas em diversos tecidos do homem.

Músculo esquelético. o músculo esquelético do homem adulto representa quase $43 \%$ do peso corpóreo e $39 \%$ da proteína corpórea total (WIDDOWSON, 1968). Aproximadamente 60 a $65 \%$ da proteína do músculo esquelético estão associados com as fibras contrácteis que consistem principalmente em três proteinas estruturais: miosina, actina e tropomiosina (YOUNG, 1970). A miosina é a proteína encontrada em maior quantidade, sendo responsável por cerca de $54 \%$ da proteína estrutural fibrilar total, comparada a 21\% de actina (HANSON \& LOWY, 1964) ou um terço da proteína total no másculo esquelético (PERRY, 1967); portanto, as fibras contrácteis representam cerca de $28 \%$ do teor protéico total do corpo adulto de mamíferos e devem, consequientemente, ter grande importância para a economia protéica do homem.

A proteína sarcoplásmica ou solúvel contribui com aproximadamente $24 \%$ para o músculo esquelético e $9 \%$ para a proteína corpórea total (WIDDWSON, 1968). Contrastando com a proteina fibrilar, a proteína sarcoplásmica é uma mistura de diversas proteínas de meias-vidas variáveis, sendo algumas relativamente curtas. 
Tecido conjuntivo da Pele. A proteína do tecido conjuntivo, colágeno, representa aproximadamente um quarto da proteína corpórea em animais superiores, onde ocorre principalmente como fibras extracelulares, insoluveis (NEUBERGER \& RICHARDS, 1964; HARKNESS, 1958). Essas fibras são responsáveis por grande parte da massa organica da pele, tendão, vasos sangüíneos, ossos, dentes, córnea e humor vítreo. - colágeno também garante uma estrutura para a maior parte dos órgãos parenquimatosos, seja em sua forma fibrosa, seja organizada em membranas basais. o colágeno é singular, ‘uma vez que contém aproximadamente $14 \%$ da hidroxiprolina; a degeneração dessa proteina responde por quase toda a hidroxiprolina encontrada na urina (PROCKOP \& SJOEDSMA, 1961). A prolina é hidroxilada após sua incorporação nas subunidades do colágeno; após a degradação, a hidroxiprolina não é reutilizada para a síntese protéica (STETTEN, 1949). Na urina, 90\% da hidroxiprolina se encontram em polipéptides e $3 \%$ como aminoácido livre (ZEFF et al., 1956). A maioria dos péptides na urina, senão todos, contém ligações de prolil-hidroxiprolina, representando de 20 a 25\% da ligação de hidroxiprolina no colágeno (WELSS \& KLEIN, 1969). Quando se injeta em ratos colágeno ou gelatina marcados com ${ }^{14} \mathrm{C}, 75 \%$ da radioatividade da hidroxiprolina apresentaram-se em ${ }^{14} \mathrm{CO}_{2}$ e $25 \%$ na urina (WELSS \& KLEIN, 1969). EFRON et al. (1965) descreveram um achado urinário em um paciente portador de hidroxiprolinemia, decorrente de deficiência inerente de hidroxiprolina oxidase, enzima envolvida no catabolismo inicial de hidxoxiprolina livre (EFRON et al., 1965). A urina do paciente continha apenas $20 \%$ de hidroxiprolina em forma de ligação polipéptide, mas $80 \%$ como 
aminoácido livre. Conclui-se, desses dados, que, após o catabolismo do colágeno, 75 a $80 \%$ da hidroxiprolina sejam liberados e convertidos em dióxido de carbono, ao passo que aproximadamente de 20 a $25 \%$ da hidroxiprolina (principalmente como prolil-péptides de hidroxiprolina) são excretados na urina (WELSS \& KLEIN, 1969). O adulto excreta de 30 a $50 \mathrm{mg}$ de hidroxiprolina, diariamente; Efron concluiu, a partir dal, que aproximadamente $2 g$ de colágeno sejam degradados diariamente (EFRON, 1956). Isso representa um "turnover" diário de 0,06\% de colágeno e aproximadamente $0,9 \%$ para sintese protéica corpórea total. Esses fatos salientam a natureza metabólicamente inativa do colágeno; em conseqüência, apesar de representar quase $25 \%$ da protéica corpórea, pouca importância tem para a economia protéica diária do adulto.

A segunda principal proteína do tecido conjuntivo é a elastina, componente secundário da pele, tendões, tecido adiposo ou tecido conjuntivo frouxo de mamiferos; livre de gordura, pode representar de 60 a $70 \%$ dos ligamentos vertebrais, $50 \%$ da cartilagem elástica no ouvido externo de mamiferos, $30 \%$ da aorta intratorácica e de 11 a $20 \%$ de outras artérias do corpo (PARTRIGE, 1965). A elastina representa 3\% da proteína corpórea total (HARKNESS \& HARKNESS, 1961) e contém 1 $1 / 2$ a $2 \%$ de hidroxiprolina (PARTRIGE, 1962). Essa proteína é metabólicamente mais inativa do que o colágeno (PARTRIGE, 1962) e pouco efeito tem sobre a economia protéica do homem adulto. 


\section{Músculo}

o músculo, o mais abundante tecido do corpo, constitui cerca de metade da massa da maior parte de mamiferos adultos. Uma vez que aproximadamente $20 \%$ do peso hidratado do músculo é constituido de proteína, o músculo esquelético fornece o maior depósito de capital protéico no corpo. Devido ao seu tamanho e relativa expansibilidade durante o repouso físico, o músculo, teoricamente, representaria uma fonte adequada de proteína durante privação protéica.

Perda nitrogenada ou necessidade para o equilíbrio

Adultos, que não necessitam de nitrogênio para o crescimento, podem ser mantidos em estado de equilíbrio por uma ingestão de proteĺna igual à sua perda diária.

A principal perda obrigatória de nitrogênio ocorre através da uréia excretada pela urina. A perda através de fezes, em estado de privação protéica, é de aproximadamente um terço da perda da pele e urina e, através da pele e outras vias secundárias, chega a cerca de um décimo da perda total. MUNRo (1972), refere-se a $37 \mathrm{mg}$ por quilograma de peso corpóreo por dia, como um valor médio para adultos. As contribuições de fezes e pele são da ordem de 12 e $3 \mathrm{mg}$, respectivamente. Considerando-se mais $2 \mathrm{mg}$ para perdas secundárias diversas, como saliva, escarro e evaporação de amônia, a média das quantidades de perdas obrigatórias totais chega a cerca de $54 \mathrm{mg} / \mathrm{Kg}$ de peso corpóreo diariamente para adultos normais em dieta livre de proteína. Dando margem a dois desvios-padrão acima da média, a 
perda obrigatória totaliza $70 \mathrm{mg}$ de nitrogênio, o equivalente a $450 \mathrm{mg}$ de proteína; portanto, usando-se esse método fatorial, a ingestão protéica satisfatória para adultos normais seria de cerca de $0,5 \mathrm{~g}$ por quilograma de peso corpóreo por dia.

Apresentamos, na fig. 7, características evidentes da economia protéica em seres humanos. Apresenta a ingestao diária de 32 a $90 \mathrm{~g}$ de proteína e um "output" de 32 a $84 \mathrm{~g}$, consistindo em 20 a $72 \mathrm{~g}$ excretadas na urina, $10 \mathrm{~g}$ pelas fezes e $2 \mathrm{~g}$ através da pele.

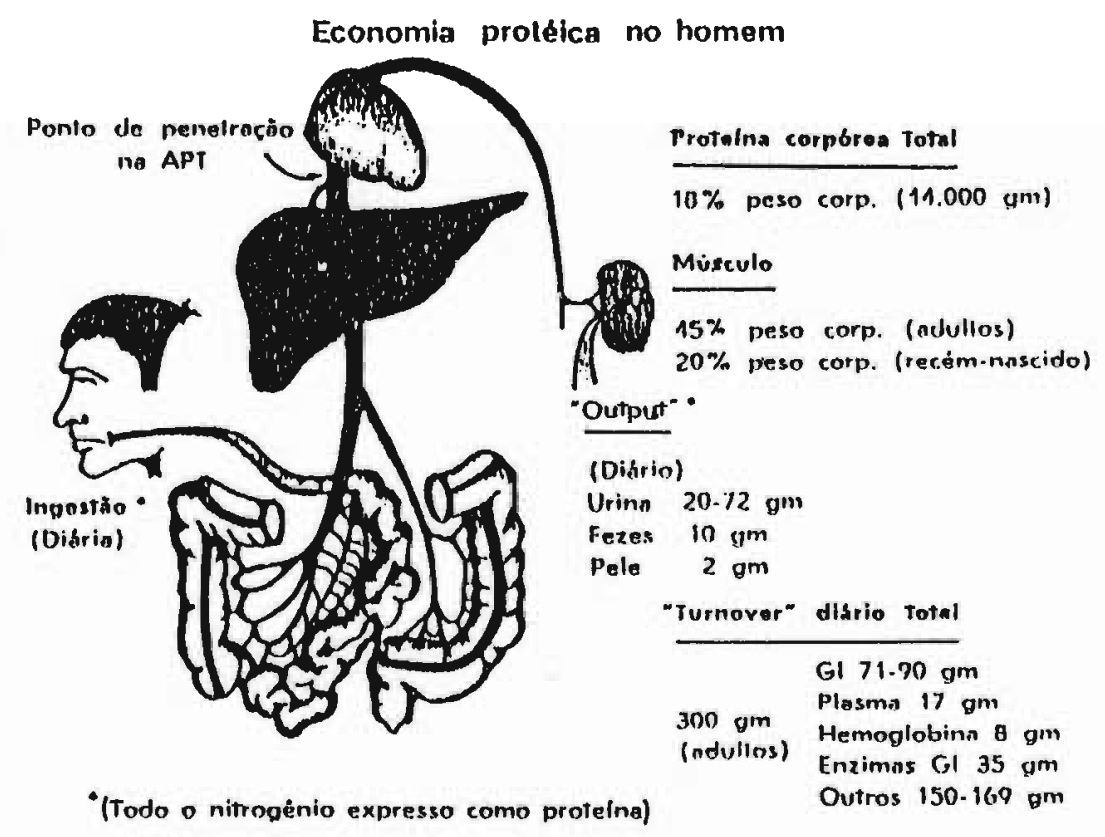

FIGURA 7 - Características da economia protéica em ser humano (GI=gastro intestinal) GHADIMI, (1975). 
- "turnover" diário é de aproximadamente 300 g/dia para adultos; os principais componentes são o trato GI(71-90g), plasma (17g), hemoglobina (8g) e enzimas GI (35g).

o diagrama mostra, também, que aminoácidos absorvidos do trato GI penetram no fígado através da veia porta; somente parte desse suprimento de aminoácidos é depurado pelo fígado para ser distribuido através do corpo. Uma grande parte dos aminoácidos que entram é usada para o ciclo de uréia de Krebs, ao passo que pequena parte é utilizada para síntese protéica e de substâncias de pequena molécula como colina, ácidos graxos e glicose. Durante o periodo de absorção, qualquer material nitrogenado, que não foi metabolizado pelas vias anteriores, atinge os tecidos extra-hepaticos através da veia hepática e veia cava.

A seta entre o fígado e o coração identifica o ponto de penetração da solução na alimentação parenteral total, demonstrando a maneira pela qual a solução omite o local da ação fisiológica do fígado e trato GI. 


\section{3 - OBJETIVO}

o presente trabalho teve por objetivo avaliar misturas de hidrolisados de colágeno através da verificação dos itens abaixo:

1-Avaliação nutricional de hidrolisado de colágeno associado a caseina em função do ganho de peso, coeficiente de eficácia proteica (CEP) e digestibilidade (CD), em ratos.

2-Essencialidade condicional da prolina em ratos durante a fase de crescimento.

3-Comprometimento hepático e renal em dietas com elevadas concentrações do hidrolisado de colágeno (superior a $25 \%)$

4-Relação entre concentração de hidroxiprolina na dieta e o teor de colágeno na pele.

5-Relaçăo entre a concentração de hidroxiprolina na dieta e a quantidade de colágeno formado através de avaliação em microscopia óptica. 


\section{4 - MATERIAL}

\section{1 - Animais}

Para os experimentos foram utilizados um total de 126 ratos (Rattus norveqicus var. albinus, Rodentia, Mamalia) de ambos os sexos, da linhagem WISTAR; após desmames e pesando entre 45 e 50 gramas obtidos a partir de colônias mantidas no biotério da Faculdade de Ciências Farmacêuticas da USP. Os animais foram divididos em 21 grupos de 6 animais, colocados em gaiolas metabólicas individuais e alimentados com ração de caseína associada ao hidrolisado de colágeno contendo 10 e $20 \%$ de proteína. Dos $10 \%$ ou $20 \%$ da proteína foram divididas conforme quadros 4 à 6 . Os experimentos foram executados em três etapas. 
5 - MÉTODOS

\section{1 - Avaliação do valor biolóqico da proteína.}

Através do coeficiente de eficácia protéica (CEP), que representa o aumento do peso do animal por grama de proteína ingerida (ASHAR \& HENRICKSON, 1982).

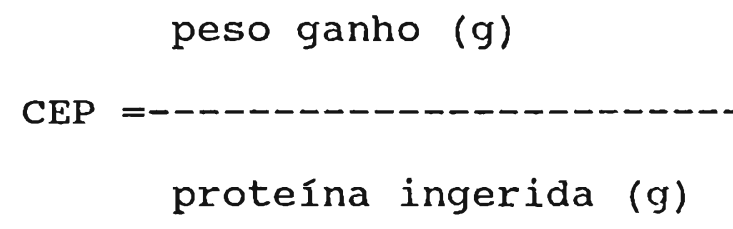

\section{2 - Determinação do coeficiente de diqestibilidade aparente $(C D)$.}

As fezes foram analisadas para verificar a quantidade de nitrogênio absorvida pelo animal através da relação (ASHAR \& HENRICKSON, 1982):

$\mathrm{N}$ dieta - $\mathrm{N}$ fezes

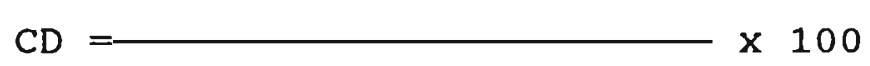

aparente $\quad \mathrm{N}$ dieta

$\mathrm{N}=$ nitrogenio 


\section{3 - Avaliação da umidade na ração}

Determinada por processo gravimétrico com emprego de calor. O material foi dessecado em estufas reguladas a $105^{\circ} \mathrm{C}$ até peso constante. (INSTITUTO ADOLFO LUTZ, 1976).

\section{4 - Determinação de lípides na ração}

Utilizamos o processo gravimétrico, baseado na extração do produto por meio de solvente especifico, no caso éter etílico, com extrator contínuo de soxhlet. (INSTITUTo ADOLFO LUTZ, 1976).

\section{5 - Determinação do nitrogênio total da ração}

o teor de nitrogênio foi determinado pelo método Micro-Kjedahl, baseado na destruição da matéria orgânica, seguido de destilação, sendo o nitrogênio dosado por volumetria utilizando-se o fator de 6,25. (INSTITUTO ADOLFO LUTZ, 1985).

\section{6 - Composicão e preparo das racões}

As rações utilizadas nos experimentos foram:

Grupo 1 - ração com $100 \%$ de fonte proteica de caseína (ração controle) .

Grupo 2 - ração contendo $75 \%$ de fonte proteica de caselna e 25\% de fonte proteica de colágeno. Este grupo foi também enriquecido com prolina e alguns aminoácidos essenciais (metionina, triptofano, tirosina e leucina). 
Grupo 3 - ração contendo $50 \%$ de fonte proteica de caseína e $50 \%$ de fonte proteica de colágeno.

Grupo 4 - ração contendo $25 \%$ de fonte proteica de caseína e $75 \%$ de fonte proteica de colágeno enriquecido com prolina e alguns aminoácidos essenciais que constam dos quadros 4,5 e 6 .

Grupo 5 - ração contendo $25 \%$ de fonte proteica de caseina e 75\% de fonte proteica de colágeno enriquecido com prolina e aminoácidos essenciais.

Grupo 6 - ração contendo $100 \%$ de fonte proteica de colágeno.

Os componentes da ração foram misturados nas proporções indicadas nos quadros 3,4 e 5 utilizando-se homogeneisador de pás e posteriormente tamisados.

As rações foram armazenadas em sacos plásticos fechados e mantidos à temperatura de $4^{\circ} \mathrm{C}$, durante 0 experimento.

A ração controle a base de caseína e composição da mistura salina (quadro 6) foi preparada segundo as recomendações do COMMITEE ON LABORATORY ANIMAL DIETS (1979).

A caseína foi fornecida pela firma "Sancro Produtos Químicos" - "Importação e Exportação". Teor de proteína de $86 \%$.

- hidrolisado de colágeno (tipo hidrogel) foi fornecedido pelas industrias "Leiner do Brasil". (PM 5000 à 20000) Teor de proteína de $90 \%$ 
Os aminoácidos metionina, triptofano, tirosina, leucina e prolina foram forcecidos pelas industrias "AJINOMOTO DO BRASIL".

A mistura vitamínica foi fornecida por "PRODUTOS ROCHE" e a composição consta no quadro 7 . 
QUADRO 4 - PREPARO DAS RAÇÕES

EXPERIMENTO 3 - TEOR DE PROTEINA 20\%

\begin{tabular}{|c|c|c|c|c|c|c|}
\hline COMPOSIÇÃO & $\stackrel{*}{*}$ & $\frac{*}{100 \%+P}$ & $\begin{array}{c}\star \\
75 \%\end{array}$ & $\begin{array}{c}\star \\
100+\mathrm{aa}\end{array}$ & $\begin{array}{c}\star \\
50 \%\end{array}$ & $\begin{array}{l}* \\
25 \%\end{array}$ \\
\hline COLÁGENO & --- & ---- & 5,0 & & 10,0 & 15,0 \\
\hline CASEINA & 20,0 & 20,0 & 15,0 & 20,0 & 10,0 & 5,0 \\
\hline AMIDO & 15,0 & 15,0 & 15,0 & 15,0 & 15,0 & 15,0 \\
\hline AÇUCAR & 50,0 & 50,0 & 50,0 & 50,0 & 50,0 & 50,0 \\
\hline FIBRA & 5,0 & 5,0 & 5,0 & 5,0 & 5,0 & 5,0 \\
\hline ÓLEO DE MILHO. & 5,0 & 5,0 & 5,0 & 5,0 & 5,0 & 5,0 \\
\hline MISTURA SALINA & 3,5 & 3,5 & 3,5 & 3,5 & 3,5 & 3,5 \\
\hline MIST. VITAMINA & 1,0 & 1,0 & 1,0 & 1,0 & 1,0 & 1,0 \\
\hline COLINA & 0,2 & 0,2 & 0,2 & 0,2 & 0,2 & 0,2 \\
\hline METIONINA ** & 0,3 & 0,3 & 0,3 & 0,43 & 0,3 & 0,3 \\
\hline TRIPTOFANO ** & ---- & ---- & --- & 0,7 & ---- & --- \\
\hline TIROSINA ** & ---- & ---- & ---- & 1,0 & --- & ---- \\
\hline LEUCINA ** & $-\cdots$ & $-\cdots$ & --- & 1,0 & ---- & ---- \\
\hline PROLINA & $-\cdots$ & 1,0 & ---- & ---- & ---- & ---- \\
\hline
\end{tabular}

$\mathrm{P}=$ Prolina

** aa = aminoácidos essenciais

* = porcentagem em relação a composição da proteína

o teor de proteína na caseína é de $86 \%$ e no colágeno é de $90 \%$. 
QUADRO 5 - PREPARO DAS RAÇÕES

EXPERIMENTO 1 - TEOR DE PROTEINA $10 \%$

\begin{tabular}{|c|c|c|c|c|c|c|}
\hline COMPOSIÇĀO & $\stackrel{*}{100 \%}$ & $\begin{array}{c}* \\
75 \%\end{array}$ & * $50 \%$ & $\begin{array}{c}* \\
25 \%\end{array}$ & $\begin{array}{c}* \\
75 \%+P\end{array}$ & $\begin{array}{c}* \\
75 \%+a a\end{array}$ \\
\hline COLÁGENO & & 2,5 & 5,0 & 7,5 & 2,5 & 2,5 \\
\hline CASEINA & 10,0 & 7,5 & 5,0 & 2,5 & 7,5 & 7.5 \\
\hline AMIDO & 15,0 & 15,0 & 15,0 & 15,0 & 15,0 & 15,0 \\
\hline AÇUCAR & 50,0 & 50,0 & 50,0 & 50,0 & 50,0 & 50,0 \\
\hline FIBRA & 5,0 & 5,0 & 5,0 & 5,0 & 5,0 & 5,0 \\
\hline ÓLEO DE MILHO & 5,0 & 5,0 & 5,0 & 5,0 & 5,0 & 5,0 \\
\hline MISTURA SALINA & 3,5 & 3,5 & 3,5 & 3,5 & 3,5 & 3,5 \\
\hline MIST. VITAMINA & 1,0 & 1,0 & 1,0 & 1,0 & 1,0 & 1,0 \\
\hline COLINA & 0,2 & 0,2 & 0,2 & 0,2 & 0,2 & 0,2 \\
\hline METIONINA & 0,3 & 0,3 & 0,3 & 0,3 & 0,3 & 0,43 \\
\hline TRIPTOFANO ** & ---- & $\cdots$ & 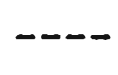 & $\cdots$ & ---- & 0,7 \\
\hline TIROSINA ** $^{*}$ & --- & --- & ---- & --- & ---- & 1,0 \\
\hline LEUCINA ** & --- & $-\cdots$ & ---- & ---- & --- & 1,0 \\
\hline PROLINA & ---- & --- & --- & ---- & 1,0 & ---- \\
\hline
\end{tabular}

P = Prolina

** aa = aminoacidos essenciais

* = porcentagem em relação a composição da proteína

o teor de proteína na caseína é de $86 \%$ e no colágeno é de $90 \%$. 
QUADRO 6 - PREPARO DAS RAÇÕES

EXPERIMENTO 2 - TEOR DE PROTEINA $10 \%$

\begin{tabular}{|c|c|c|c|c|c|c|}
\hline COMPOSIÇÃO & $\stackrel{*}{*}$ & $\begin{array}{c}* \\
75 \%\end{array}$ & $\begin{array}{c}* \\
50 \%\end{array}$ & $\begin{array}{c}* \\
35 \%\end{array}$ & $\begin{array}{c}* \\
35 \%+P\end{array}$ & $\begin{array}{c}* \\
35 \%+a a\end{array}$ \\
\hline COLÁGENO & & 2,5 & 5,0 & 6,5 & 6,5 & 6,5 \\
\hline CASEINA & 10,0 & 7,5 & 5,0 & 3,5 & 3,5 & 3,5 \\
\hline AMIDO & 15,0 & 15,0 & 15,0 & 15,0 & 15,0 & 15,0 \\
\hline AÇUCAR & 50,0 & 50,0 & 50,0 & 50,0 & 50,0 & 50,0 \\
\hline FIBRA & 5,0 & 5,0 & 5,0 & 5,0 & 5,0 & 5,0 \\
\hline ÓLEO DE MILHO & 5,0 & 5,0 & 5,0 & 5,0 & 5,0 & 5,0 \\
\hline MISTURA SALINA & 3,5 & 3,5 & 3,5 & 3,5 & 3,5 & 3,5 \\
\hline MIST. VITAMINA & 1,0 & 1,0 & 1,0 & 1,0 & 1,0 & 1,0 \\
\hline COLINA & 0,2 & 0,2 & 0,2 & 0,2 & 0,2 & 0,2 \\
\hline METIONINA ** & 0,3 & 0,3 & 0,3 & 0,3 & 0,3 & 0,43 \\
\hline TRIPTOFANO * * & --- & ---- & ---- & ---- & ---- & 0,7 \\
\hline TIROSINA ** & $--\cdots$ & $-\cdots-$ & ---- & ---- & ---- & 1,0 \\
\hline LEUCINA ** & --- & ---- & $-\cdots$ & ---- & $-\cdots$ & 1,0 \\
\hline PROLINA & --- & --- & ---- & --- & 1,0 & --- \\
\hline
\end{tabular}

P = Prolina

** aa = aminoácidos essenciais

* = porcentagem em relação a composição da proteína

O teor de proteína na caseína é de $86 \%$ e no colágeno é de $90 \%$. 
QUADRO 7 - COMPOSIÇÃO DA MISTURA VITAMÍNICA

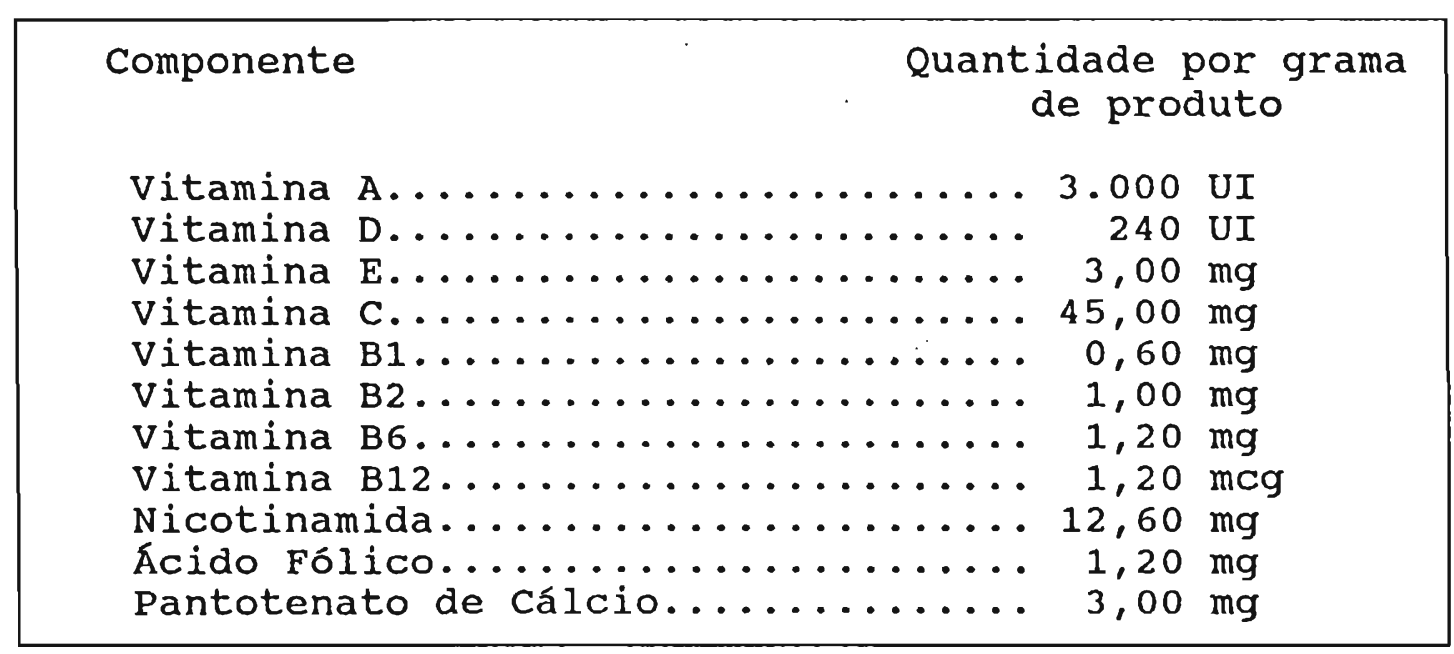

Fornecido por LABORATÓRIO ROCHE DO BRASIL Tipo SOY Nutrix.

Mistura salina preparada em nosso laboratório conforme a composição em anexo (quadro 7A).

QUADRO 7A - COMPOSIÇÃO DA MISTURA SALINA

Componente

Fosfato de cálcio dibásico.................5500,00

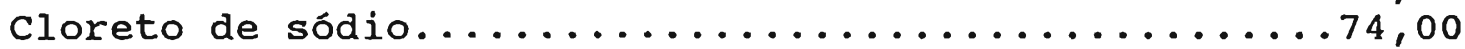

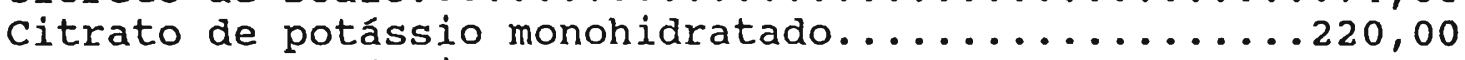

Sulfato de potássio.....................52,00

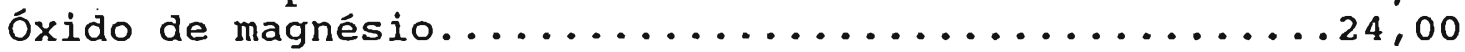

Carbonato manganoso $43-48 \%$ de Mn................... 50

Citrato férrico $16-17 \%$ de Fe................... 00

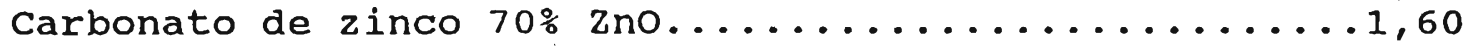

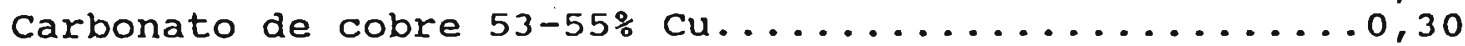

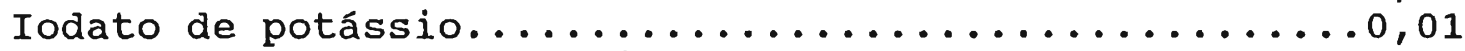

Selenito de sódio pentahidratado................... 01

Sulfato de potássio crômico dodecahidratado......... 0,55

Açucar fino.............................118, 03

COMMITEE ON LABORATORY ANIMAL DIETS 1979 


\section{7 - Procedimento experimental}

Os ratos recém-desmamados foram separados em 21 grupos de 6 ratos, colocados em gaiolas metabólicas individuais e receberam alimentação "ad. libitium" por periodo de 28 dias.

\section{8 - Ensaios Biológicos.}

Os resultados referentes ao ganho de peso dos animais acham-se expressos nas tabelas 1,2 e 3 bem como o consumo de ração, teor de nitrogênio, ganho de peso, coeficiente de eficácia protelca e coeficiente de digestibilidade aparente dos diferentes grupos estudados.

\section{9 - Análise estatística}

Os valores dos diversos parâmetros estudados foram submetidos a análise de variância.

\subsection{0 - Doseamento de hidroxiprolina}

A pele de dois animais de cada grupo foram parcialmente removidas e depiladas, secas em estufa a $80^{\circ} \mathrm{C}$, desengorduradas em éter anidro e pulverizadas.

Procedeu-se $\circ$ doseamento da hidroxiprolina pelo método colorimétrico descrito por WOESSNER JR. (1961).

\subsection{1 - Verificação histológica do colágeno da pele}

Os animais do experimento 2 com $10 \%$ de proteína, foram sacrificados logo após o término do experimento quando 
foram colhidas amostras do tecido epidérmico dorsal dos animais depilados e fixados em Bouin e incluidos em parafina e cortados em micrótomo em fatias de 5 micrometros de espessura e avaliado histológicamente por microscopia óptica.

\subsection{2- Exame histopatológico de fígado, rim e histológico de pele}

Os fragmentos de fígado foram fixados em formaldeído a $4 \%$ e após inclusão em parafina submetidos a cortes de 5 micra de espessura em micrótomo rotatório American óptical modelo 820. O material foi corado pelo método hematoxilina-eosina (PEARSE, 1968).

Os fragmentos de pele foram incluidos em parafina, cortados em fatias de 5 micrometros e corados pela técnica de hematoxilina-eosina (PEARSE, 1968).

\subsection{3- Análise de aminoácidos}

Aminogramas foram obtidos pelo analisador de aminoácidos tipo Beckmam modelo 7300 obtidos no Departamento de Ciencias dos Alimentos da FCF USP. 


\section{1 - Composição centesimal das rações}

Para este estudo, preparamos rações aos níveis protéicos de $20 \%$ e $10 \%$, tomando-se como referência protéica a caseína.

Após análise da composição centesimal das rações, mostrados nos quadros 8 e 9 observou-se que os valores obtidos encontram-se dentro dos valores delineados experimentalmente.

Utilizamos nos ensaios rações contendo $10 \%$ a $20 \%$ de proteína. Com $10 \%$ de proteína todo o nitrogênio presente é destinado para fins plásticos, pois o excedente das necessidades proteícas do animal, quando utilizado para sua função primária de construção de tecido, bem como os lípides e carboidratos, serão transformados em calorias e posteriormente em gordura de reserva, uma vez que o organismo não apresenta reserva protéica. 
QUADRO 8- Resultados porcentuais da composição das rações do experimento 1 (com teor de proteina a 10\%).

\begin{tabular}{|l|c|c|c|}
\hline RAÇÕES & $\begin{array}{c}\text { UMIDADE } \\
(g)\end{array}$ & $\begin{array}{c}\text { PROTEINA } \\
(g)\end{array}$ & $\begin{array}{c}\text { LIPIDES } \\
(g)\end{array}$ \\
\hline caseína 100 & 5,2 & 11,57 & 5,6 \\
\hline $\begin{array}{l}\text { caseína 75\% } \\
\text { colágeno 25\% }\end{array}$ & 5,5 & 11,97 & 5,8 \\
\hline $\begin{array}{l}\text { caseína 50\% } \\
\text { colágeno 50\% }\end{array}$ & 6,0 & 11,09 & 5,4 \\
\hline $\begin{array}{l}\text { caseína 25\% } \\
\text { colágeno 75\% }\end{array}$ & 5,8 & 9,47 & 5,8 \\
\hline $\begin{array}{l}\text { caseína 75\% } \\
\text { colágeno 25\% } \\
\text { prolina 1\% }\end{array}$ & 6,0 & 11,61 & 5,7 \\
\hline $\begin{array}{l}\text { caseína 75\% } \\
\text { AA }\end{array}$ & 5,6 & 11,21 & 5,5 \\
\hline
\end{tabular}

* Metionina 0,13\%; Triptofano 0,7\%; Tirosina $1,0 \%$; Leucina $1,0 \%$. 
QUADRO 9 - Resultados porcentuais da composição das rações do experimento 2 (com teor de proteina de 16\%).

\begin{tabular}{|l|c|c|c|}
\hline RAÇÕES & $\begin{array}{c}\text { UMIDADE } \\
(g)\end{array}$ & $\begin{array}{c}\text { PROTEINA } \\
(g)\end{array}$ & $\begin{array}{c}\text { LIPIDES } \\
(g)\end{array}$ \\
\hline caseína 100 & 6,3 & 16,14 & 6,8 \\
\hline $\begin{array}{l}\text { caseína 75\% } \\
\text { colágeno 25\% }\end{array}$ & 6,0 & 15,04 & 7,0 \\
\hline $\begin{array}{l}\text { caseina 50\% } \\
\text { colágeno 50\% }\end{array}$ & 5,8 & 14,56 & 6,9 \\
\hline $\begin{array}{l}\text { caseina 35\% } \\
\text { colágeno 65\% }\end{array}$ & 5,4 & 17,21 & 7,1 \\
\hline $\begin{array}{l}\text { caseina 35\% } \\
\text { polágeno 65\% } \\
\text { prolina 1\% }\end{array}$ & 6,2 & 17,93 & 6,9 \\
\hline $\begin{array}{l}\text { caseína 35\% } \\
\text { colágeno 65\% } \\
\text { AA }\end{array}$ & 6,0 & 16,42 & 7,0 \\
\hline
\end{tabular}

AA-Metionina $0,13 \%$; Triptofano $0,7 \%$; Tirosina $1 \%$; Leucina $1 \%$ 


\section{2 - Valor biológico das rações}

\section{2 .1 - Ganho de Peso}

Analisando o tabela 1 e gráfico 1 e 1 A onde 0 teor de proteína foi de $19,13 \%$ na ração podemos verificar que para os diferentes grupos estudados houve variações tanto do peso como da quantidade de ração consumida. Considerando o grupo padrão de caseína $100 \%$ (grupo 1) observamos que a adição de $25 \%$ de colágeno a caseína (grupo 3) diminuiu o ganho de peso em 3,0\% e - consumo em $3,0 \%$. A mesma ração adicionada de aminoácidos essenciais apresenta diferença aproximada menos de 5\% tanto para ganho de peso quanto para consumo. Já a adição de prolina elevou o ganho em $0,6 \%$ e o consumo em 5\%.

Porcentagens iguais de caseína e colágeno apresentaram diferença de ganho de peso de $30 \%$ e consumo de ração de $20 \%$.

Na ração com $25 \%$ de colágeno (grupo 3 da tabela 1) a diferença no ganho foi de $86 \%$ e o consumo de 56\%.

Portanto verificamos que quanto maior a adição de colágeno, maior o consumo de ração sem aumentar o ganho de peso e que em nível de adição de $25 \%$ de colágeno esta variação não foi muito significativa. Nos resultados obtidos a adição de prolina mostrou maior índice de crescimento que o padrão embora esta diferença esteja incorporada dentro do erro estatístico. Porém é demonstrativo de uma tendência, o que não ocorreu com a adição de aminoácidos essenciais. 


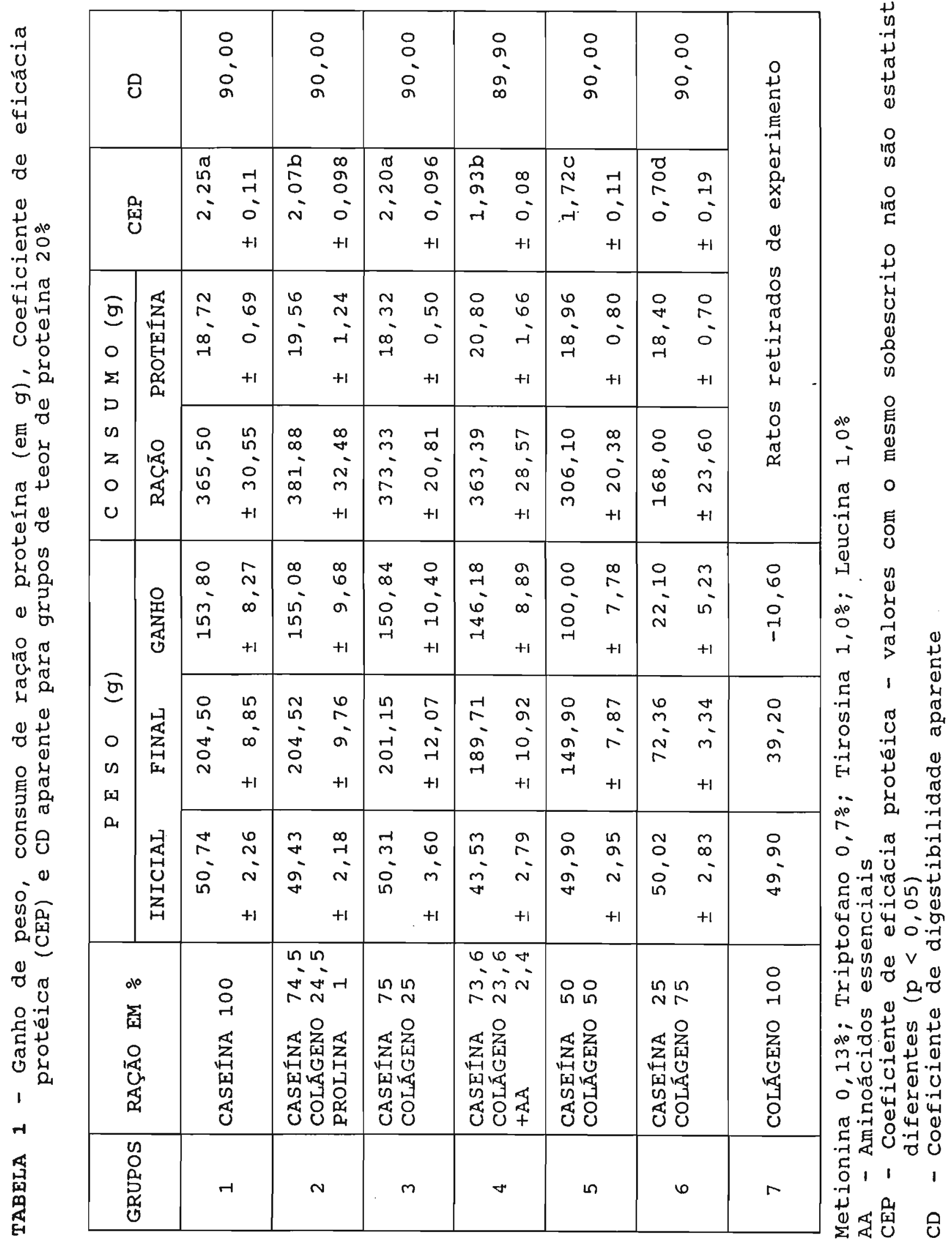


GRAFICO 1- AUMENTO DE PESO $(\mathrm{g})$, CONSUMO DE RACT̃O E COEFICIÊNTE DE EFICÁCIA PROTEICA (CEP) REFEREENTES AOS GRUPOS DA TABELA 1 (ALIMENTADOS COM DIFERÊNTES RAÇÕES:)

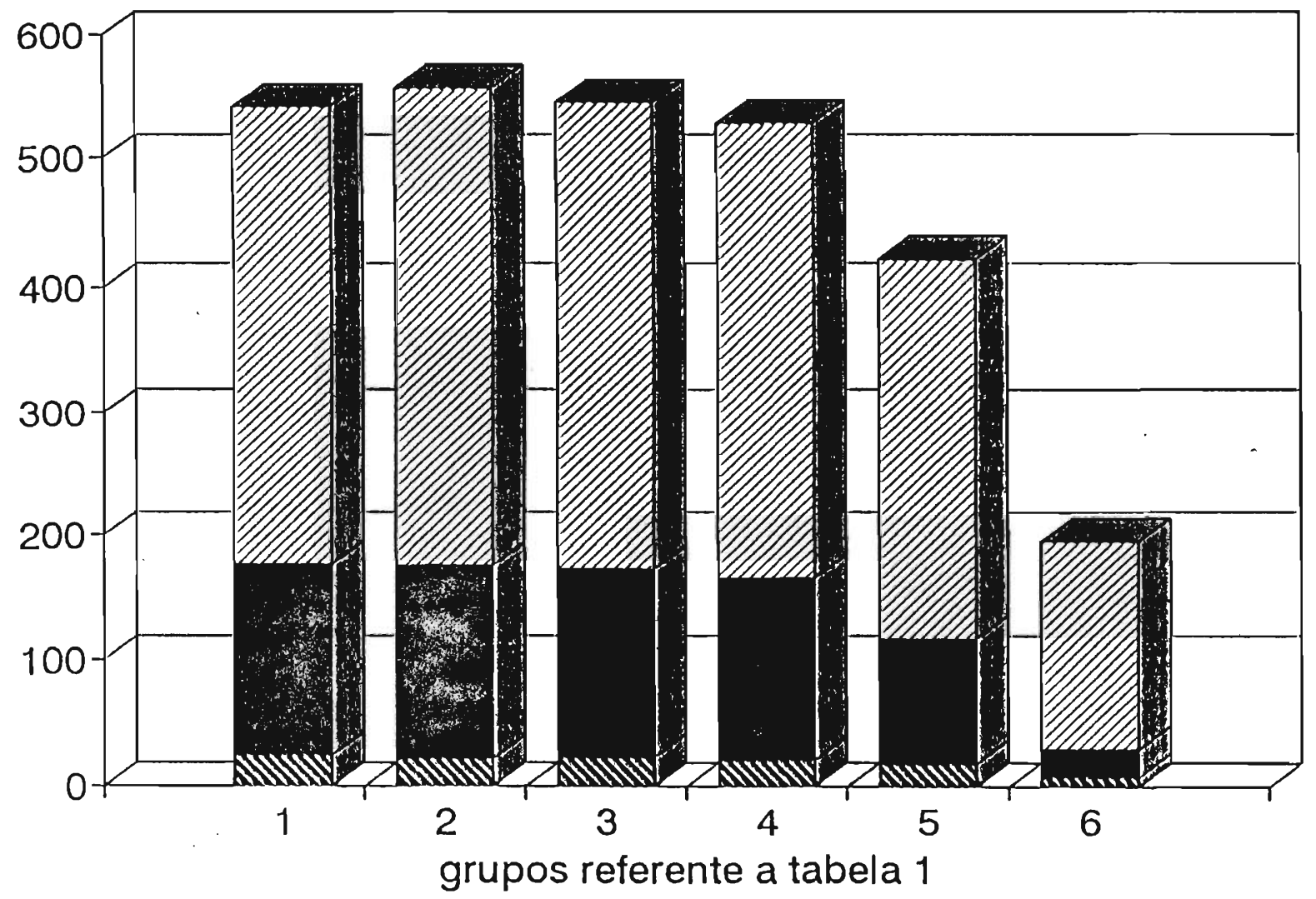




\subsection{2 - Coeficiente de eficácia protéica CEP}

o coeficiente de eficácia protéica é um indice que relaciona o crescimento ao consumo de rações. Portanto é um sensor da qualidade nutricional da ração e relaciona o teor de proteína da ração (gráfico 1 e 1A), que pode apresentar variações que influenciem no resultado final. A partir da quantidade de proteína ingerida pelos animais, podemos determinar o coeficiente de eficácia protéica (CEP), que possibilita a análise representativa do aproveitamento da protelna para fins biológicos.

Pela análise dos resultados pode ser verificado que a adição de prolina e aminoácidos essenciais à ração com $75 \%$ de caseína não causaram grandes alterações no coeficiente de eficácia protéica e que a adição de $25 \%$ de hidrolisado de colágeno à ração com $75 \%$ de caseína não modificou o valor do CEP, em relação ao padrão de $100 \%$ de caseína. Isto vem demonstrar os dados da literatura (LEE et al., 1978), de que a adição de $25 \%$ de colágeno não promove queda significativa no valor nutritivo da proteína, quando ela apresenta um alto valor nutricional. Em níveis de 50\% de adição de colágeno houve diminuição do valor nutricional na associação de proteĺna.

\section{Digestibilidade Aparente}

Uma proteína pode conter todos os aminoácidos essenciais e apresentar baixo rendimento biológico, devido a problemas de digestibilidade. Por este motivo foi analisado também o coeficiente de digestibilidade aparente das rações, através do nitrogênio eliminado nas fezes. 
Os valores obtidos pela digestibilidade aparente variaram entre $89 \%$ e $90 \%$ (Tabelas 1,2 e 3 )

Dados de BABJI et al. (1980) apresentam para caseína CEP de 2,5 e digestibilidade aparente de 85. Dietas ricas em colageno apresentaram CEP entre 2,3 a 2,5 e digestibilidade de 87 a 90. Dados semelhantes também foram encontrados por JEWELL et al. (1980).

HOPPICH et al. (1975) apresentaram valores de digestibilidade aparente de 88 a 90 e HENDRICKS et al. (1977) de 88 a 87 para dieta em tecido animal contendo colágeno.

Experimento com $10 \%$ de proteína na ração foram delineados conforme quadros 2 e 3 .

$\mathrm{Na}$ tabela 1 apresentamos os resultados para $20 \%$ de proteína e na tabela 2 e gráfico 2 e $2 A$ utilizou-se $10 \%$ de proteína a ração. Porém o experimento com $10 \%$ de proteina obteve-se CEP de 2,9 para a ração padrão de caseína e 2,3 para rações com $75 \%$ de caseína e $25 \%$ de colágeno. Os resultados deste experimento são similares aos obtidos na tabela 1 com 20\% de proteína. Portanto os resultados para 10 e $20 \%$ de proteína na ração mostraram-se com pequena diferença.

o enriquecimento da ração com aminoácidos essenciais tanto no tabela 1 quanto na tabela 2 e gráfico 2 e 2 A não demonstraram alterações no CEP.

Estes resultados serão analisados posteriormente a partir dos tabelas 4 a 9 no item composição aminoacidica. 
o enriquecimento com prolina não alterou o CEP em relação a ração não enriquecida.

A digestibilidade apresentadas nas tabelas 1,2 e 3 apresentam-se em torno de $90 \%$ em conformidade com a literatura citada.

A ração com $50 \%$ de colágeno e $50 \%$ de caseína apresentou CEP de 1,83 e a com 25\% e de caseína, 75\% colágeno CEP de 0,44. Portanto quanto maior o teor de colágeno na ração, menor o valor nutricional da mesma. 


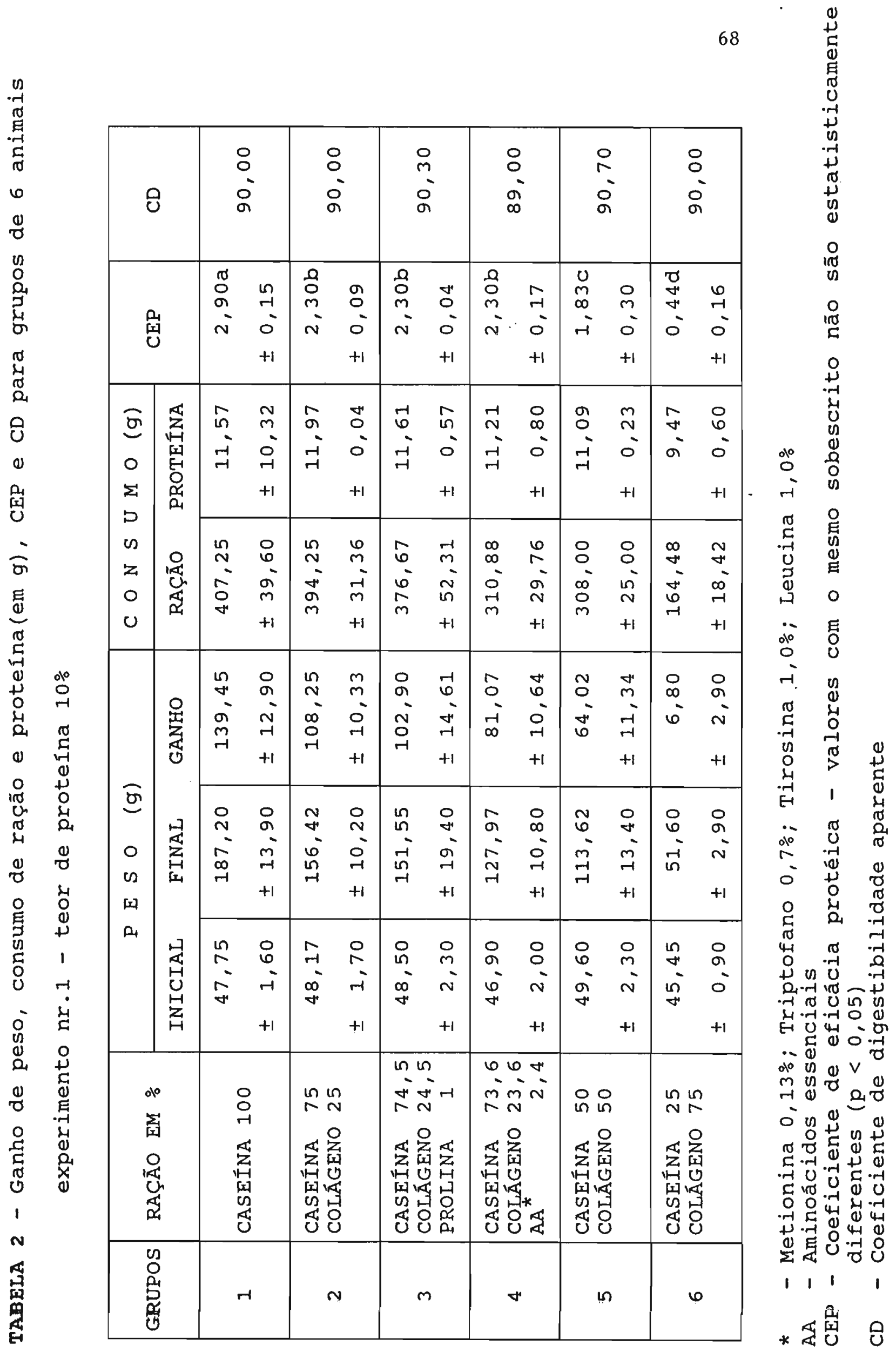


GRKRTCO 2- AURENTO DE PESO (\&), CONSUMO DE RACAOO E COEFTCTENTE DE EFICACTA TROTETCA (CER) REFERNTE AOS GRUPOS DA TABELA 2( ALTMENTADOS COM DTFERENTES RAÇOES )

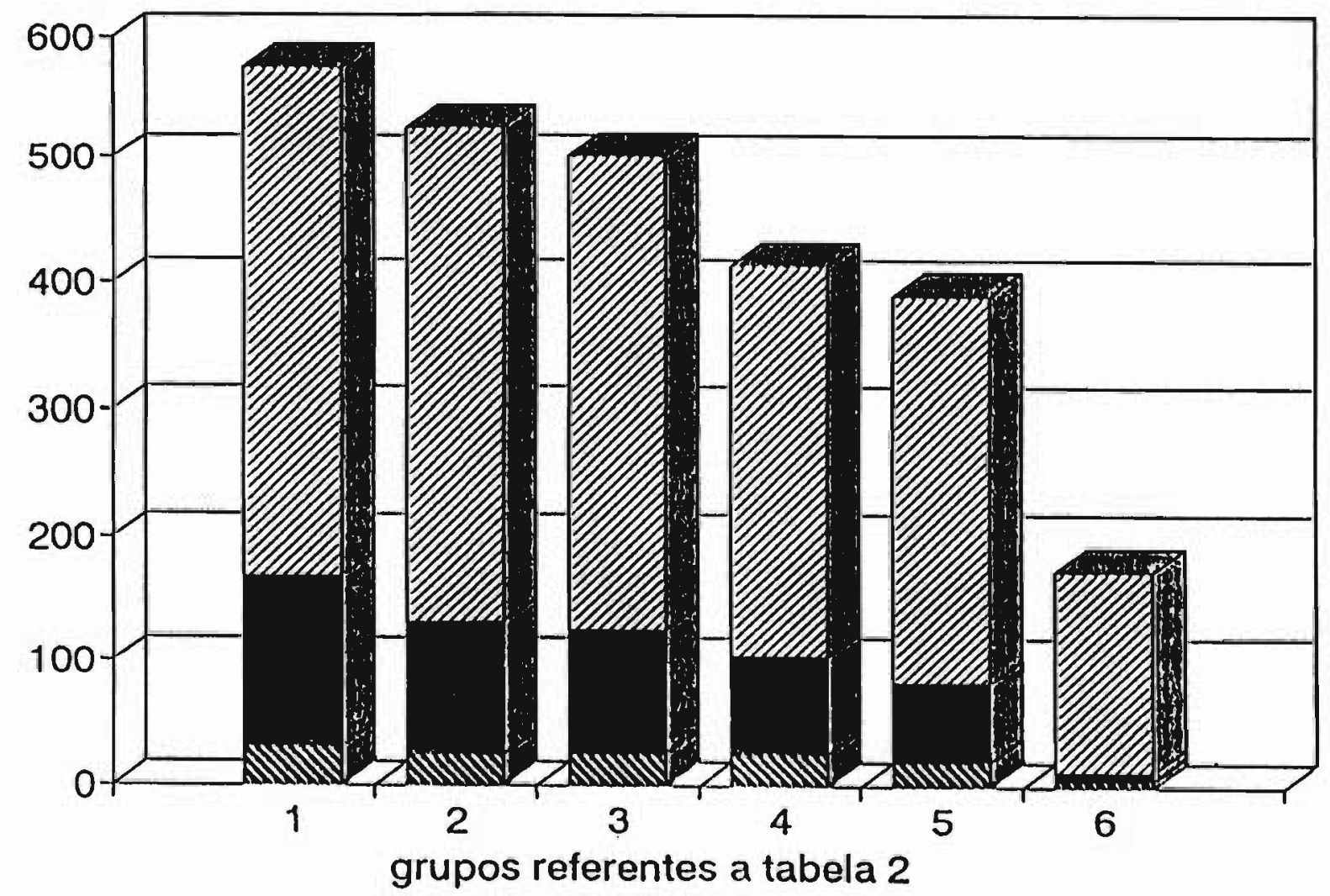

CEP aumento de peso WIIIS consumo de ração

CER - RELACXTO ENTRE GANUO DE PESO E TEOR DE PROTEINA TNGERIDA 
GRAFICO 2A- VARIAÇ̃̃o dO COEFICIENTE dE EFICÁCIA PROTEICA NOS GRUPOS 1 a 6 DA TABELA 2

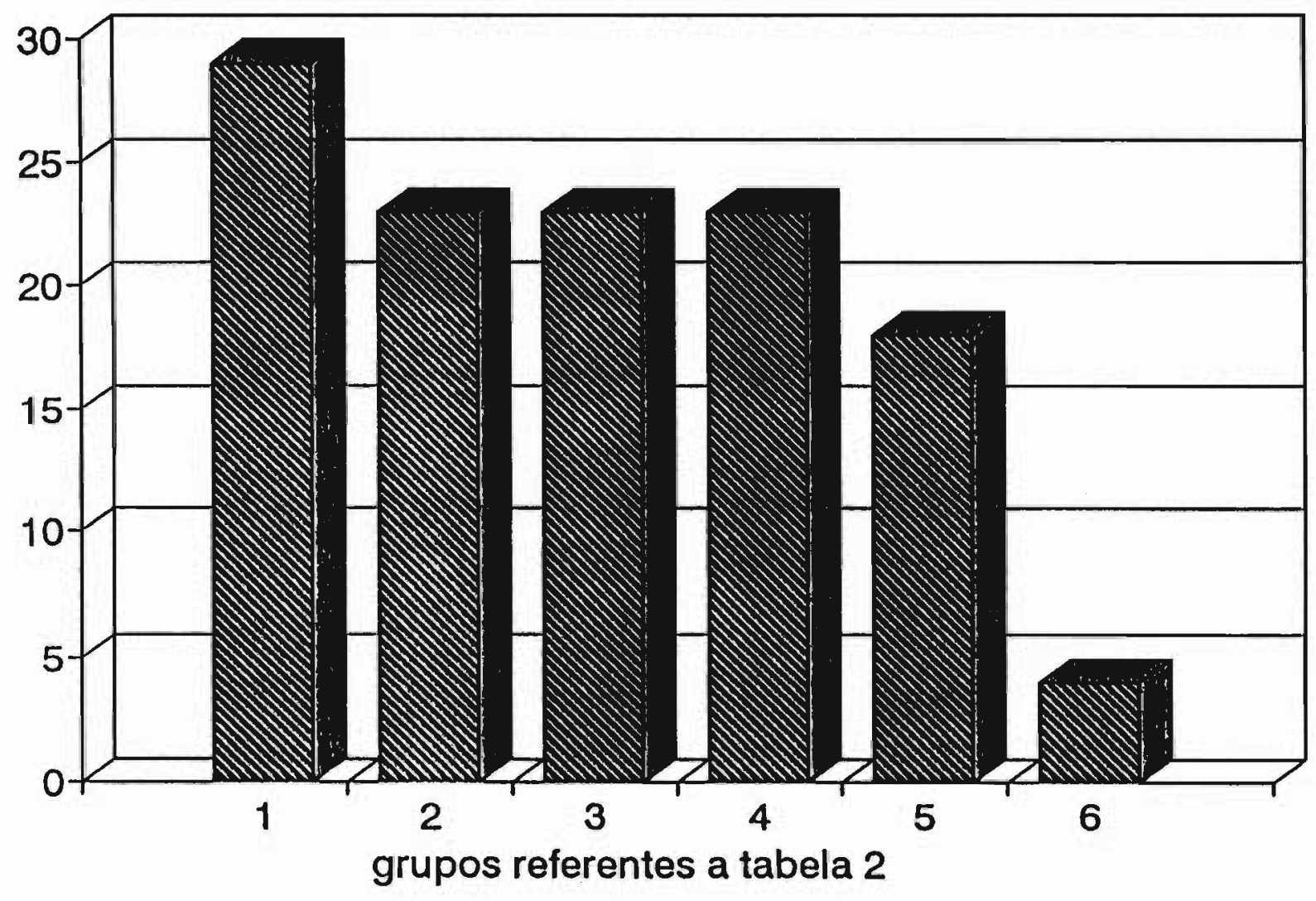

\section{NMW CEP}


Demonstrando como já citado anteriormente na literatura que adição de colágeno no máximo de $28 \%$ da quantidade da proteína total na dieta decai seu valor nutritivo (LEE et al., 1978).

o gráfico 2 e 2 A mostra as variações entre aumento de peso, consumo de ração e CEP obtidos no tabela 2 e gráfico $2 \mathrm{~A}$.

\section{Prolina como aminoacido essencial}

A fim de sabermos a que nível a prolina é condicionalmente essencial passamos a enriquecer a ração em níveis altos de adições de colágeno. Repetiu-se os experimentos com $100 \%$ caseína 75 e $50 \%$ a fim de confirmar os resultados anteriores e enriquecemos com prolina e aminoácidos essenciais a ração com caseína $35 \%$ e colágeno $65 \%$. Os resultados deste experimento constam da tabela 3 , gráfico 3 e $3 A$ onde podemos observar que os resultados de CEP para os grupos de caseina $100 \%, 75 \%$ e $50 \%$ são mais baixos que os obtidos na tabela 2 e gráfico 2A. Este fato deve-se provavelmente aos problemas ocorridos no condicionador de ar do biotério durante o experimento, que ocasionou um aumento da temperatura da sala e consequentemente levou a uma maior ingestão de líquido pelos animais. Porém a tendência dos resultados estão coerentes com os dados anteriores.

Comparando a adição de prolina e aminoácidos essenciais ao grupo controle com $65 \%$ de colágeno, verificamos que a adição de prolina fez decair em 50\% o valor do CEP e a adição de aminoácidos essenciais comparativo ao padrão apresentou CEP 3,25 vezes maior. 


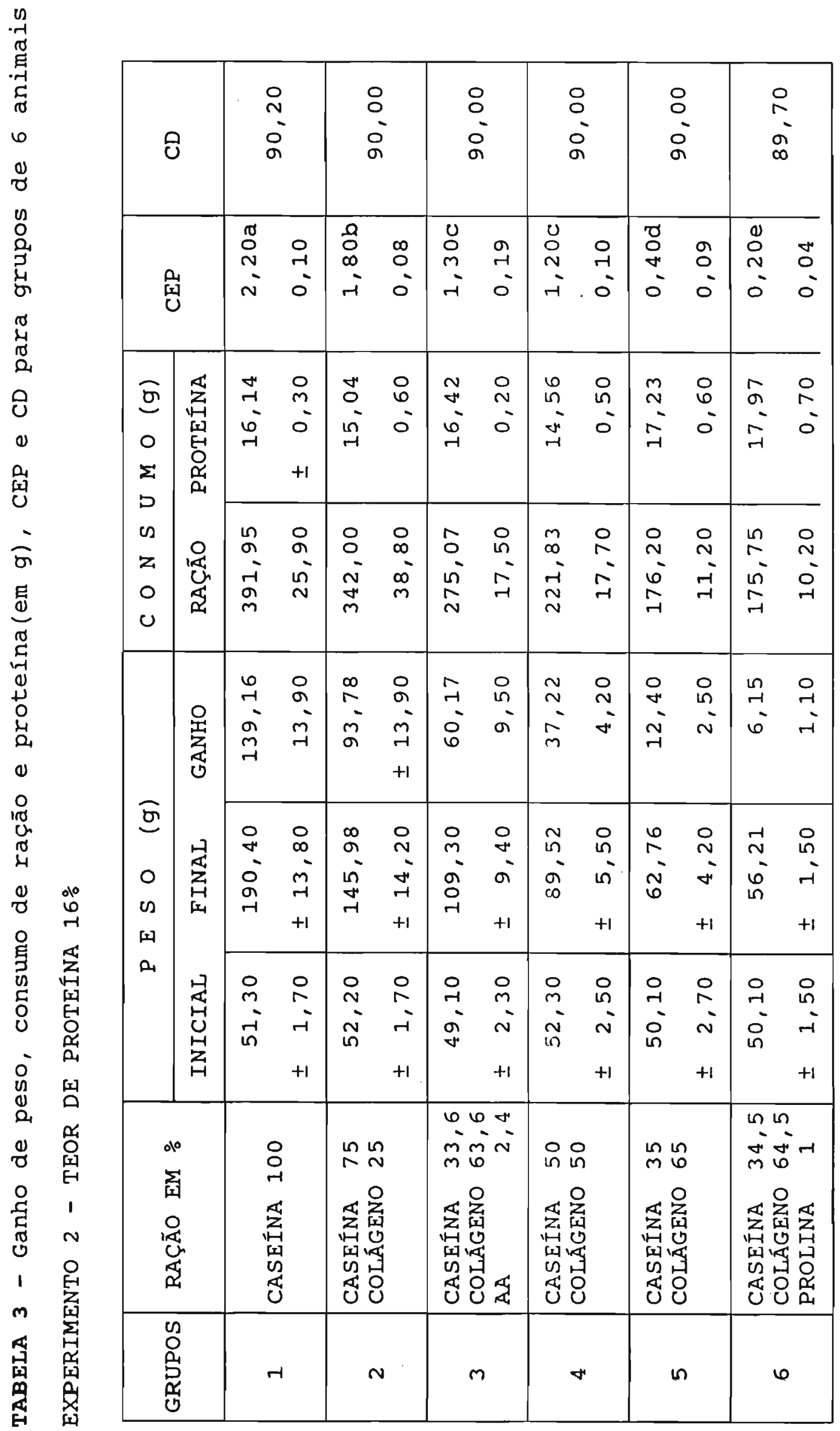

in

$\stackrel{10}{2}$

D
-1
4
0
0
01
0
0
0

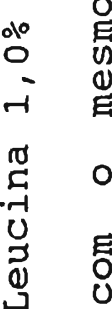

oio y

ㄴ.

\%

.

ก 1 เ

$\rightarrow$ ก

- 0.4

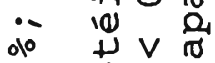

$\therefore \quad 0$

○ मे.

- थ

द $\quad 000.7$

फ

० 100

पी 0 . म्न

.

म्र.न बै

सU ठ . 워 이 थn तथ बै व $\therefore$ 표 ○ 时范。

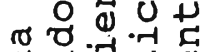
C.

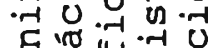
0 ० +.7 - 50 元 4

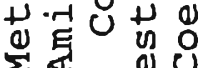
1111

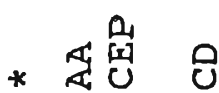


GRKFTCO 3- AUMENTO DE PESO(g); CONSUMO DE RACÃ̃O E COEFTCIENTE DE EFICÁCIA PROTEICA (CEP) REFEREMTE AOS GRUPOS DA TABELA 3 ( ALTMENTADOS COM DIFERENTES RACÕES )

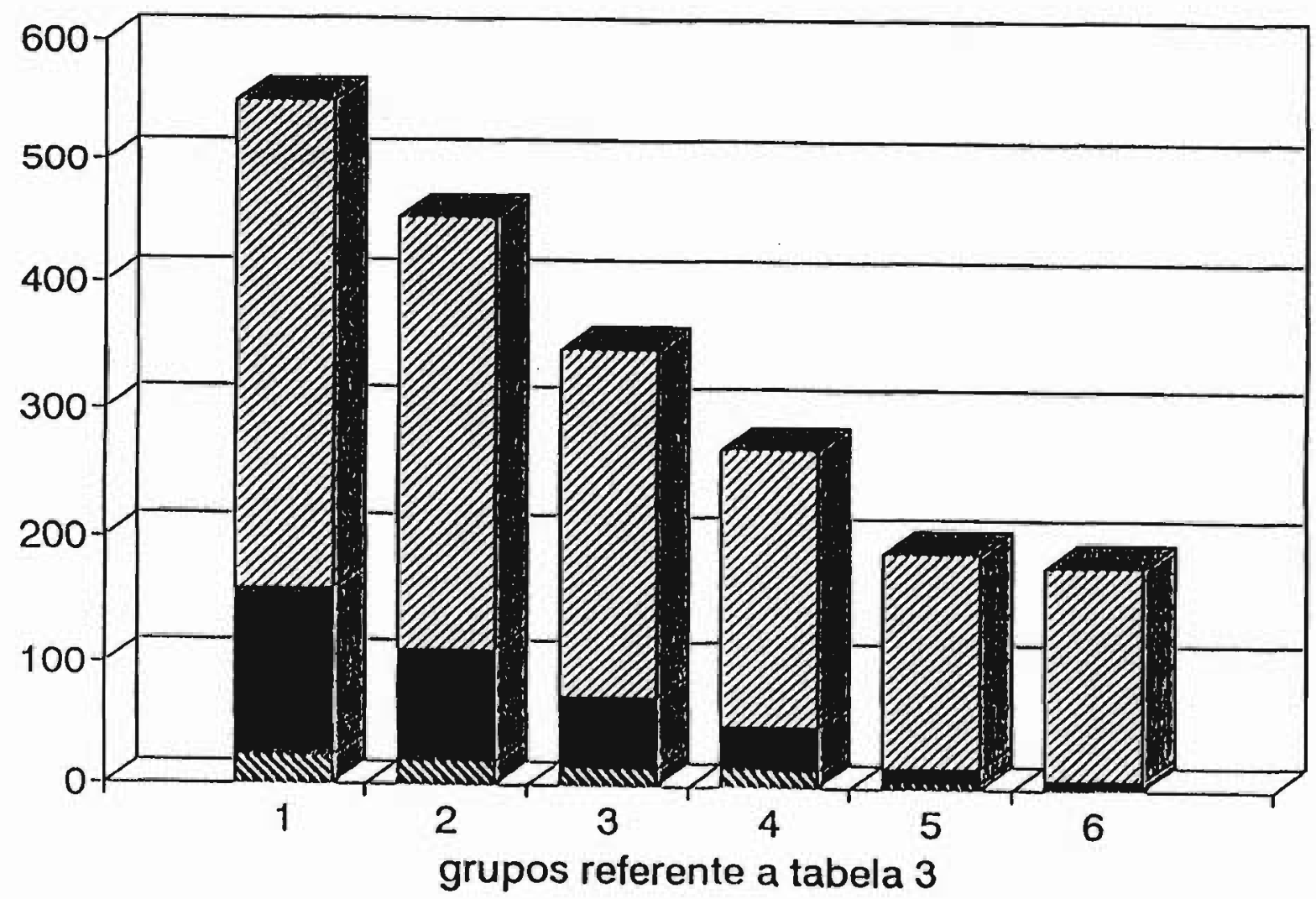

AMW CEP aumento de peso WIIll consumo de ração

CEP - RELACÃO ENTTE GANIO DE PESO E TEOR DE PROTEINA INGERIDA 
GRAFTCO 3A- VARTACĀO DO COEFTCTENTE DE EFICACTA PROTETCA NOS GRUPOS 1 a 6 DA TABELA 3.

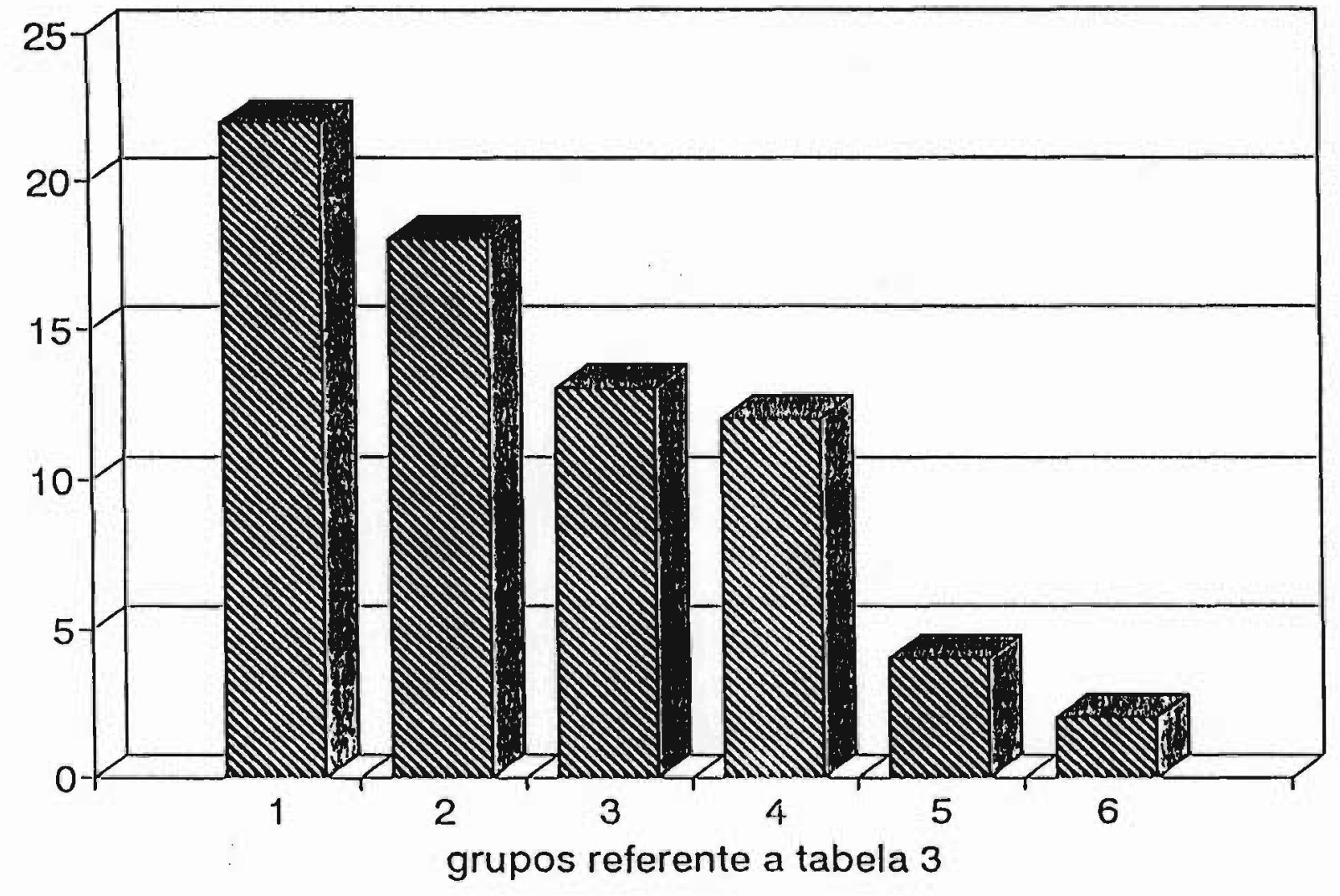

\section{CEP}


Os resultados obtidos com o acréscimo de aminoacidos essenciais estão descritos nas tabelas 4 a 9 e o gráfico 4 apresenta a relação aminoacídica da proteína.

Em leitões recém-nascidos a prolina livre encontra-se em baixa concentração no plasma em relação aos outros aminoácidos (CUPERLOUVIC, 1967; BENGTSSON, 1971; ATKINSON 1977) entretanto, após o desmame a prolina livre aumenta 4 vezes mais no plasma e no fígado, tornando-se $\circ$ mais abundante dos aminoácidos livres (BENGTSSON, 1972; ATKINSON, 1977).

varios trabalhos que demonstram que dieta suplementada com prolina aumenta o crescimento em frangos (GREENE et al.,1962, SUGAHARA e ARIYOSHI, 1967; GRABE \& BARKER, 1973; BARKER 1977) .

o experimento 1 - tabela 1, contendo $20 \%$ de proteina na ração e o experimento 2 - tabela 2 , contendo $10 \%$ de proteina na ração enriquecida com prolina também demonstraram que a prolina na adição de $1 \%$ no grupo 2 e grupo 3 respectivamente não alterou o crescimento de ratos recém-desmamados, no grupo 2 da tabela 1 o resultado de ganho de peso e CEP mostraram ligeiramente mais alto em relação ao grupo controle (grupo 3) demonstrando desta forma uma tendência de que o enriquecimento de prolina a proteínas bem balanceadas pode ter carater de essencialidade condicional como já estudado por autores como descrito na revisão. A adição de prolina a proteínas de baixo valor nutricional como na Tabela 3 grupo 6 demonstram que esta piorou ainda mais a qualidade da proteína. 
Nossos resultados demonstraram que para o estudo da essencialidade condicional da prolina, deve-se considerar como carater prioritário a composição aminoacidica da proténa total, bem como o teor de arginina pode alterar o teor de hidroxiprolina como descrito por GHADIMI, 1977. 


\section{3 - Composição aminoacídica das rações}

o valor biológico de uma proteína é caracterizado pela quantidade e tipo da composição aminoacidica da fonte protéica.

Os aminogramas utilizados nos experimentos constaram das tabelas 4 e 9 sendo os aminogramas dos tabelas 5 e 8 calculados a partir dos padrões caseína e colágeno. Constando também dos tabelas 5 à 7 o enriquecimento com aminoácidos essenciais.

Sabemos que o valor biológico de uma proteína não depende exclusivamente de seu conteudo de aminoacidos essenciais, uma vez que a quantidade total de aminoácidos essenciais, relacionada com o teor total de nitrogênio da proteína, pode nos indicar a capacidade da mesma em contruir tecido que é, em última análise, o objetivo básico a ser atingido (HARPER, 1983).

o colágeno é uma protéina isenta de triptofano; portanto sem valor nutricional equilibrado quando utilizada como fonte protéica em rações. Uma ração composta com $20 \%$ de proteína, tendo o colágeno como unica fonte protéica, demonstrou, em nosso experimento, um valor de CEP negativo (tabela 1), resultado este também encontrado por HOPPICH et al. (1975) .

Entretanto, a combinação desta fonte protéica rica em prolina e hidroxiprolina a outra proteína de alto valor 
nutricional como a caseína, pode viabilizar a utilização desta fonte obtida de subproduto de abatedouro (tabela 1).

Na tabela 10 é apresentado o teor de aminoácidos essenciais das diferentes rações estudadas. Estes resultados podem ser melhor visualizados através do gráfico 4, onde verificamos que a maior parte dos aminoácidos essenciais é formada pelos aromáticos e, em menor escala, pelos sulfurados.

$\mathrm{Na}$ seqüência de gráficos apresentados verificamos que a quantidade de aminoácidos essenciais decresce com o acréscimo do teor de colágeno à ração. Portanto o acréscimo de colágeno promove desbalanceamento e diminuição em relação ao teor de aminoácidos essenciais da ração. Os gráficos 4B e 4C apresentam - teor de aminoácidos essenciais na ração padrão acrescida de 25\% de colágeno e a mesma ração enriquecida com aminoácidos essenciais. Os gráficos $4 \mathrm{E}$ e $4 \mathrm{~F}$ mostram os resultados padrão e enriquecido com adição de $65 \%$ de colágeno. Segundo estes resultados os gráficos não apresentam modificações significativas.

No quadro 10 verificamos que o cômputo químico dos aminoácidos essenciais calculado para as diferentes rações apresentou aumento em aproximadamente $7 \%$ das rações enriquecidas em relação à padrão, independente do nível de colágeno das rações. Os CEP apresentados nos quadros 2 e 3 demonstram que o enriquecimento das rações acrescidas de $65 \%$ de colágeno promoveu um melhor balanceamento da mistura protéica em relação à adição de $25 \%$ de colágeno. A ração com $65 \%$ de 
colágeno após enriquecimento com aminoácidos essenciais apresentou um CEP 3 vezes maior em relação à padrão. 
Quadro 10 - Computo Químico dos aminoácidos essenciais das rações estudadas.

\begin{tabular}{|l|c|}
\hline Composição das rações & Computo Químico \\
\hline Caseína 100\% & 100,0 \\
\hline Caseína 75\% & \\
Colágeno 25\% & 85,95 \\
\hline Caseína 73,6\% & \\
Colágeno 23,6\% & 92,35 \\
+ AA essenciais 2,4\% & \\
\hline Caseína 50\% & \\
Colágeno 50\% & 71,85 \\
\hline Caseína 33,6\% & \\
Colágeno 63,6\% & \\
+AA essenciais 2,4\% & \\
\hline Colágeno 65\% & \\
\hline Colágeno 75\% & \\
\hline
\end{tabular}

Cômputo Químico $=g / 100 \mathrm{~g}$ proteína teste $\times 100$ $g / 100 \mathrm{~g}$ proteína padrão

AA - Aminoácidos essenciais, Metionina 0,13\%, Triptofano 7\%, Tirosina $1 \%$ e Leucina $1 \%$. 
TABELA 4 - Teor em aminoácidos ( $/ 100 \mathrm{~g}$ de proteína) presentes na proteína caseína $100 \%$.

\begin{tabular}{|c|c|}
\hline Aminoácidos & g/100g de Proteína \\
\hline Lisina & 7,28 \\
\hline Histidina & 2,70 \\
\hline Arginina & 2,95 \\
\hline Triptofano & 1,66 \\
\hline Ácido Aspártico + Asparagina & 9,00 \\
\hline Treonina & 4,30 \\
\hline Serina & 5,07 \\
\hline Ácido Glutâmico + Glutamina & 21,90 \\
\hline Prolina & 9,60 \\
\hline Glicina & 1,78 \\
\hline Alanina & 2,80 \\
\hline $1 / 2$ Cistina & $-\cdots$ \\
\hline Valina & 5,90 \\
\hline Metionina & 1,86 \\
\hline Isoleucina & 4,80 \\
\hline Leucina & 8,89 \\
\hline Tirosina & 4,48 \\
\hline Fenilalanina & 5,03 \\
\hline
\end{tabular}


TABELA 5 - Teor em aminoácidos (g/100g de proteína) presentes na proteína caseína 75\% + colágeno 25\% calculados a partir das tabelas 4 e 9 .

\begin{tabular}{|c|c|}
\hline Aminoácidos & g/100g de Proteína \\
\hline Lisina & 6,49 \\
\hline Histidina & 2,22 \\
\hline Arginina & 4,14 \\
\hline Triptofano & 1,25 \\
\hline Acido Aspártico + Asparagina & 9,51 \\
\hline Treonina & 3,79 \\
\hline Serina & 4,65 \\
\hline Ácido Glutâmico + Glutamina & 19,09 \\
\hline Prolina & 10,86 \\
\hline Glicina & 8,25 \\
\hline Alanina & 3,43 \\
\hline 1/2 Cistina & 0,03 \\
\hline Valina & 5,06 \\
\hline Metionina & 1,55 \\
\hline Isoleucina & 4,11 \\
\hline Leucina & 7,61 \\
\hline Tirosina & 3,50 \\
\hline Fenilalanina & 4,60 \\
\hline Hidroxiprolina & ---- \\
\hline
\end{tabular}

Este aminograma foi acrescido com prolina de $1 \%$ e acrescido dos aminoácidos essenciais metionina $0,013 \%$ triptofano $0,7 \%$ tirosina $1 \%$ leucina $1 \%$. 
TABELA 6 - Teor em aminoácidos (g/100g de proteína) presentes na proteina caseína 50\% + colágeno 50\% calculados a partir das tabelas 4 e 9 .

\begin{tabular}{lc}
\hline \hline Aminoacidos & g/100g de Proteina \\
\hline \hline Lisina & 5,72 \\
\hline Histidina & 1,73 \\
\hline Arginina & 5,32 \\
\hline Triptofano & 0,83 \\
\hline Acido Aspártico + Asparagina & 10,03 \\
\hline Treonina & 3,26 \\
\hline Serina & 4,23 \\
\hline Acido Glutâmico + Glutamina & 16,27 \\
\hline Prolina & 11,93 \\
\hline Glicina & 14,73 \\
\hline Alanina & 4,05 \\
\hline 1/2 Cistina & 0,05 \\
\hline Valina & 4,21 \\
\hline Metionina & 1,23 \\
\hline Isoleucina & 3,42 \\
\hline Leucina & 6,33 \\
\hline Tirosina & 2,54 \\
\hline Fenilalanina & 4,17 \\
\hline Hidroxiprolina & ---- \\
\hline \hline
\end{tabular}


TABELA 7 - Teor em aminoácidos (g/100g de proteina) presentes na proteína caseína 35\%, colágeno 65\%, enriquecido com prolina, e triptofano, metionina, isoleucina, leucina e tirosina calculados a partir das tabelas 4 e 9 .

\begin{tabular}{|c|c|}
\hline Aminoácidos & g/100g de Proteína \\
\hline Lisina & 5,20 \\
\hline Histidina & 3,50 \\
\hline Arginina & 6,00 \\
\hline Triptofano & 0,58 \\
\hline Ácido Aspártico + Asparagina & 10,30 \\
\hline Treonina & 3,01 \\
\hline Serina & 3,95 \\
\hline Ácido Glutâmico + Glutamina & 14,55 \\
\hline Prolina & 12,60 \\
\hline Glicina & 18,55 \\
\hline Alanina & 4,40 \\
\hline $1 / 2$ Cistina & 0,07 \\
\hline Valina & 3,70 \\
\hline Metionina & 1,00 \\
\hline Isoleucina & 3,00 \\
\hline Leucina & 5,55 \\
\hline Tirosina & 1,96 \\
\hline Fenilalanina & 3,90 \\
\hline Hidroxiprolina & --- \\
\hline
\end{tabular}

Este aminograma foi acrescido de prolina a $1 \%$ e acrescido dos aminoácidos essenciais metionina 0,13\%, triptofano 0,7\%, irosina $1 \%$ e leucina $1 \%$ 
TABELA 8 - Teor em aminoácidos (g/100g de proteína) presentes na proteína caseína 25\% + colágeno 75\% calculado a partir das tabelas 4 e 9 .

\begin{tabular}{|c|c|}
\hline Aminoácidos & g/100g de Proteína \\
\hline Lisina & 4,92 \\
\hline Histidina & 1,25 \\
\hline Arginina & 6,53 \\
\hline Triptofano & 0,42 \\
\hline Ácido Aspártico + Asparagina & 10,54 \\
\hline Treonina & 2,75 \\
\hline Serina & 3,81 \\
\hline Ácido Glutâmico + Glutamina & 13,47 \\
\hline Prolina & 13,09 \\
\hline Glicina & 21,18 \\
\hline Alanina & 4,67 \\
\hline $1 / 2$ Cistina & 0,08 \\
\hline Valina & 3,37 \\
\hline Metionina & 0,92 \\
\hline Isoleucina & 2,73 \\
\hline Leucina & 5,03 \\
\hline Tirosina & 1,57 \\
\hline Fenilalanina & 3,74 \\
\hline Hidroxiprolina & --- \\
\hline
\end{tabular}


TABELA 9 - Teor em aminoácidos ( $\mathrm{g} / 100 \mathrm{~g}$ de proteína) presentes na proteína colágeno 100\% "hidrogel".

\begin{tabular}{|c|c|}
\hline Aminoácidos & g/100g de Proteína \\
\hline Lisina & 4,12 \\
\hline Histidina & 0,76 \\
\hline Arginina & 7,70 \\
\hline Triptofano & ---- \\
\hline Ácido Aspártico + Asparagina & 11,05 \\
\hline Treonina & 2,22 \\
\hline Serina & 3,38 \\
\hline Ácido Glutâmico + Glutamina & 10,65 \\
\hline Prolina & 14,25 \\
\hline Glicina & 27,65 \\
\hline Alanina & 5,30 \\
\hline 1/2 Cistina & 0,10 \\
\hline Valina & 2,52 \\
\hline Metionina & 0,60 \\
\hline Isoleucina & 2,04 \\
\hline Leucina & 3,75 \\
\hline Tirosina & 0,60 \\
\hline Fenilalanina & 3,31 \\
\hline Hidroxiprolina & ---- \\
\hline
\end{tabular}


ڤ

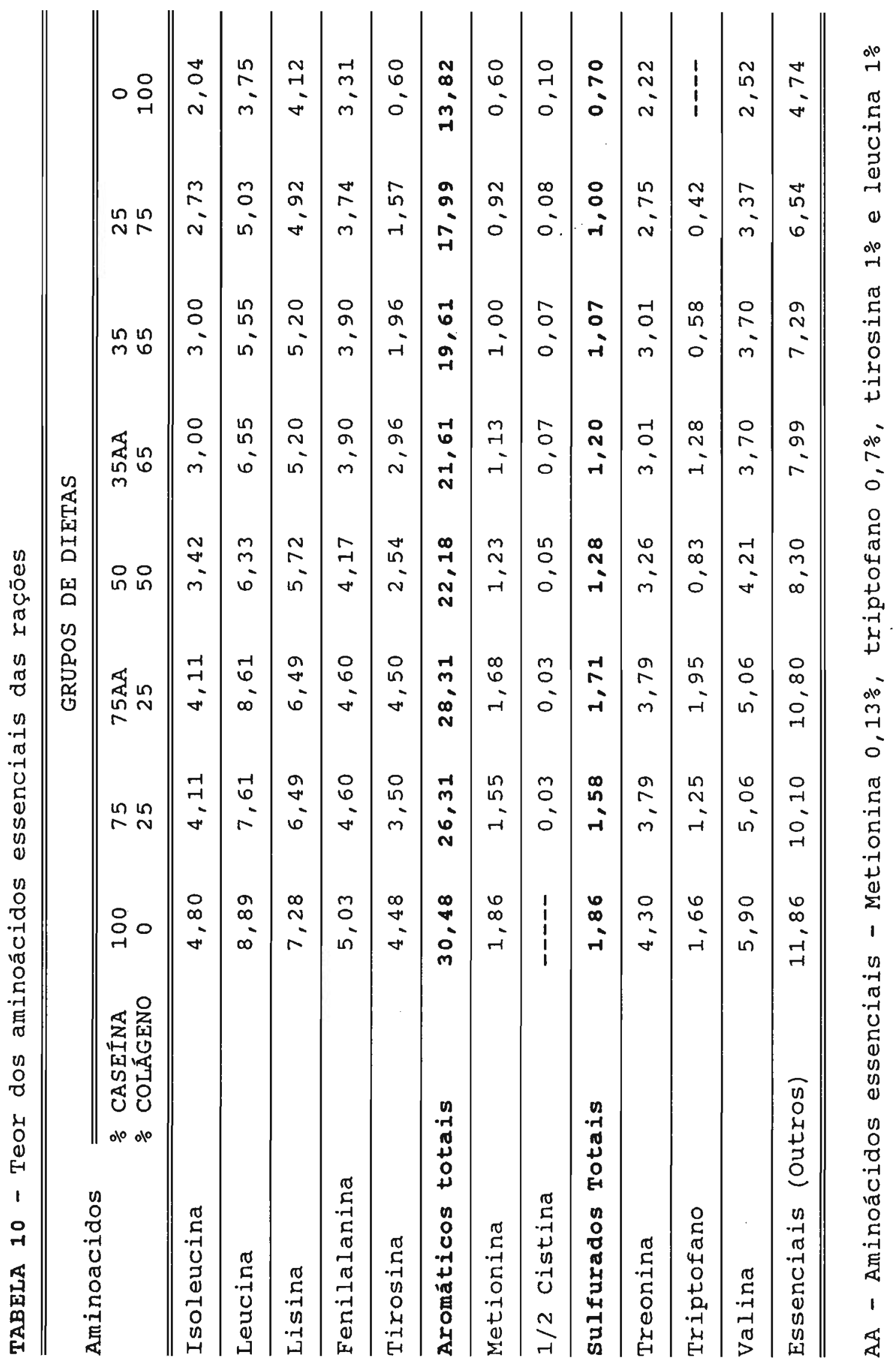


GRAFICO 4- RESULTADOS PERCENTUATS DOS AMINOKCIDOS ESSENCIATS DA TABELA 10

AMINOÁCIDOS NÃO ESSÊNCIAIS $(55.8 \%)$

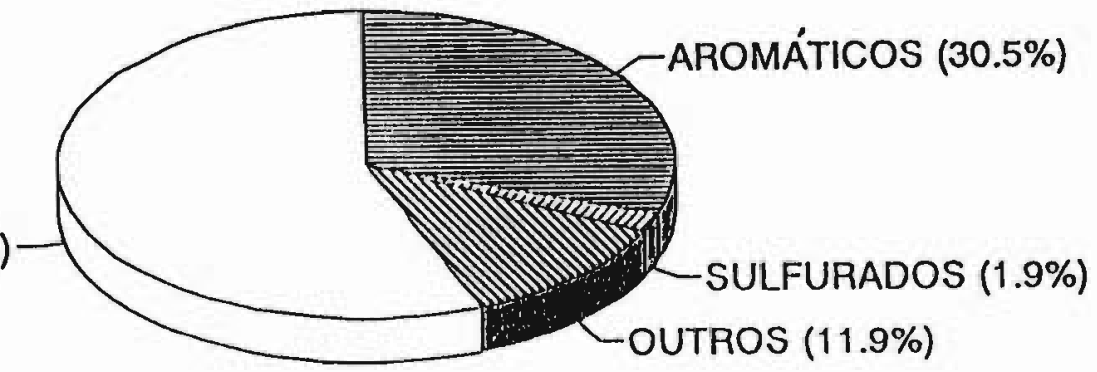

$$
\text { 4a- dieta contendo } 100 \% \text { de caseína }
$$

AMINOÁCIDOS NÃO ESSÊNCIAIS

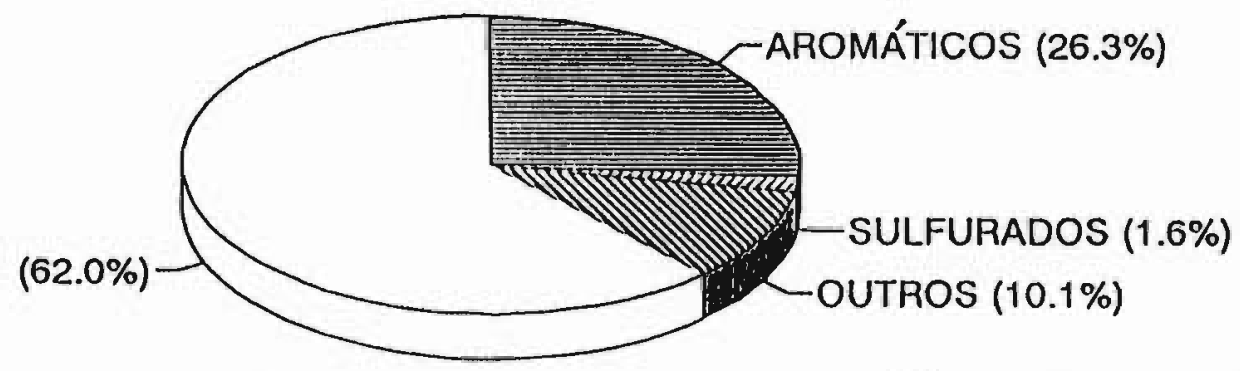

4b- dieta contendo $75 \%$ de caseína e $25 \%$ de colágeno

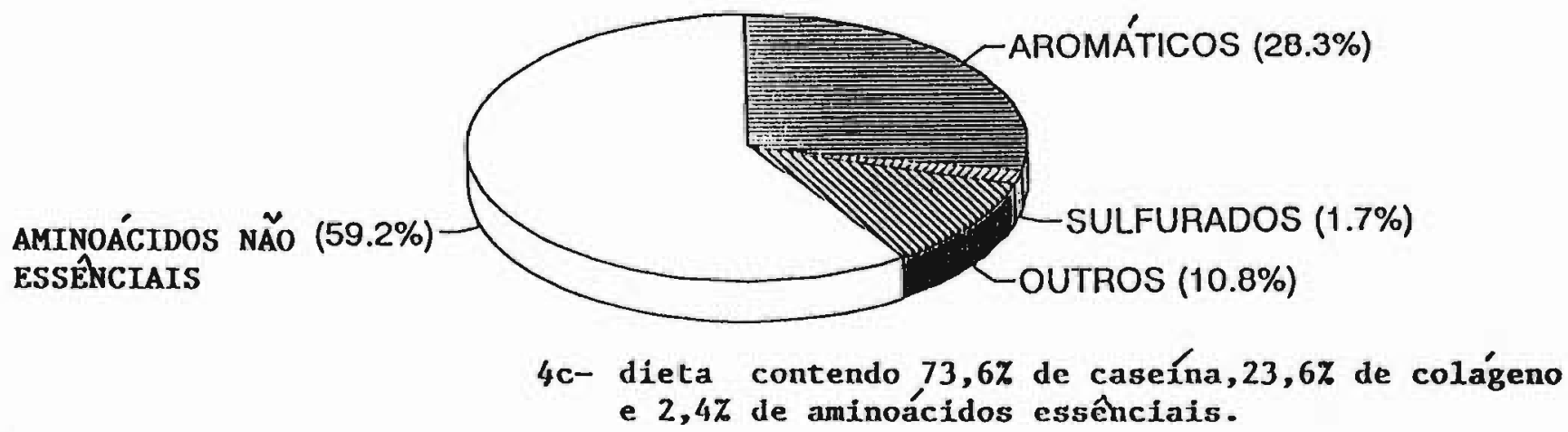

AMINOÁCTIDOS NÃO ESSÊNCIAIS

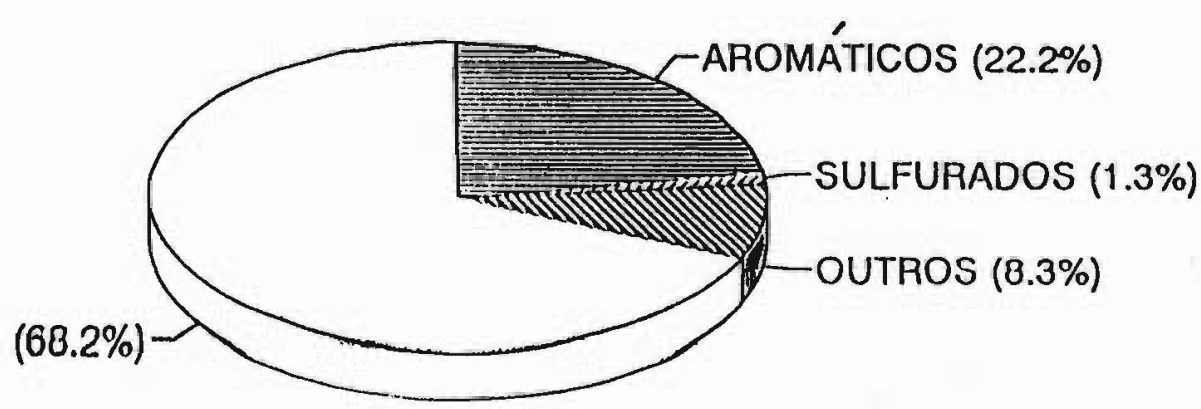

4d- dieta contendo $50 \%$ de caseína e $50 \%$ de colágeno 


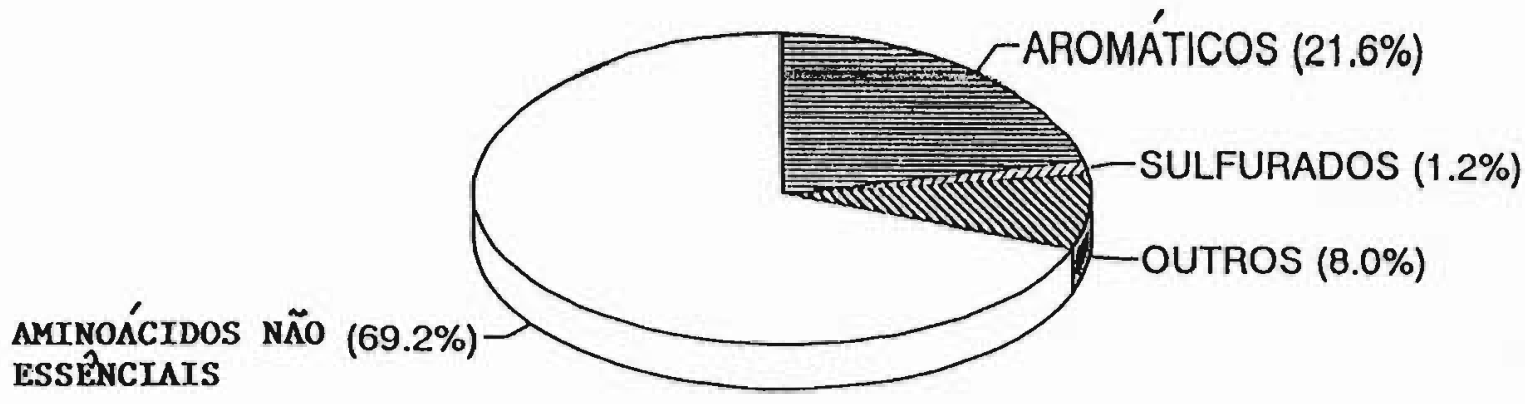

4e- dieta contendo $33,6 \%$ de caseína, 63,67 e 2,4\% de aminoácidos essênciais

AMINOÁCIDOS NÃO ESSÊNCIAIS

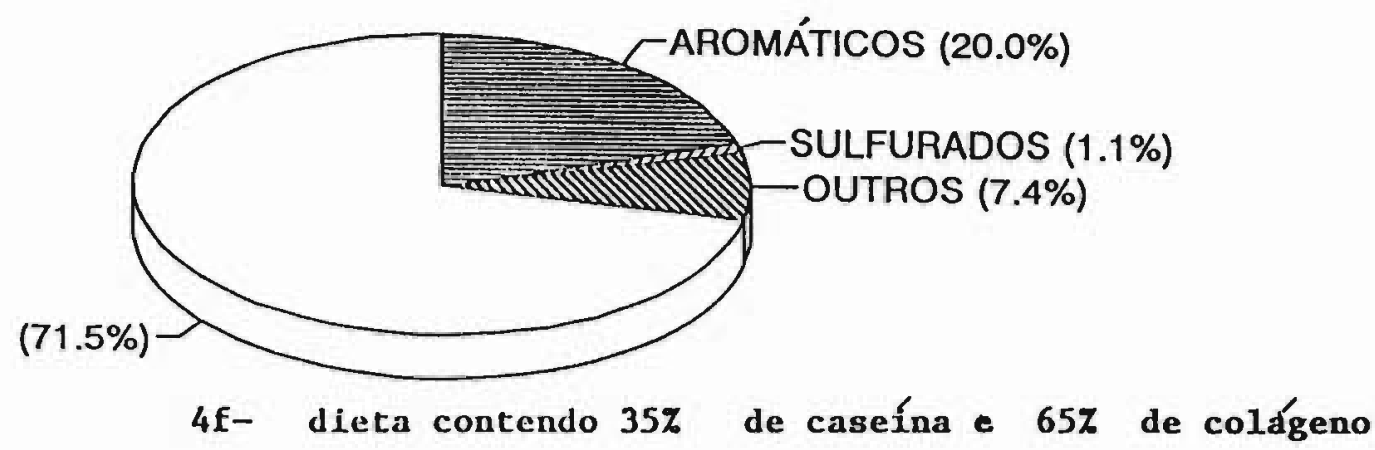

AMINOÁCIDOS NÂO ESSỀNCIAIS

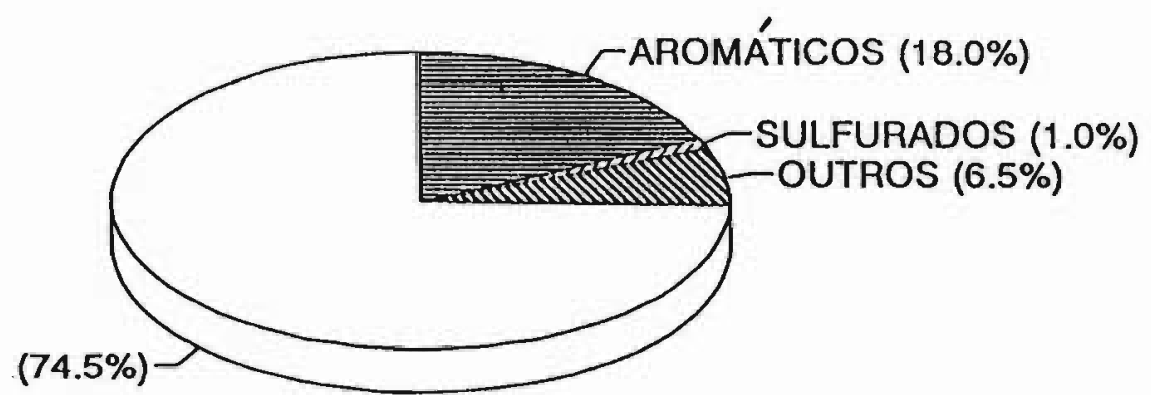

4g-dietas contendo 257 de caseína e $75 z$ de colágeno

AMINOÁCIDOS NẪo ESSENCIAIS

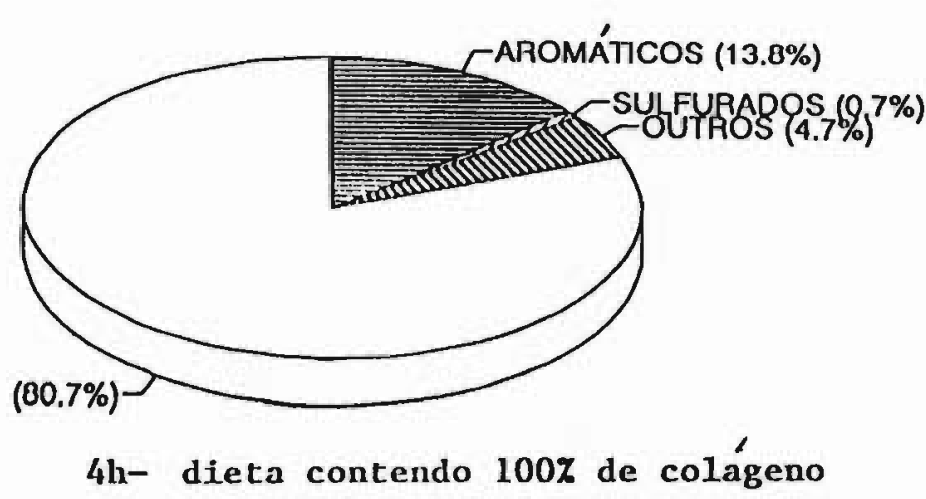

M essenciais = triptofano, tirosina, leucina e metionina 


\section{4 - Avaliação histopatológica do fígado e rim}

Todos os cortes histológicos examinados mostraram, com intensidades variáveis os seguintes aspectos:

Presença de espaços claros no citoplasma de hepatócitos, acometendo porções variadas do parênquima. Alguns cortes mostraram presença de vacúolos no citoplasma dos hepatócitos. Núcleos de aspecto normal.

A avaliação histológica dos fígados tem como finalidade detectar se a composição protéica das rações pode promover alterações estruturais desses orgãos.

Quando a ingestão de proteínas e carboidratos é alta, - fígado degrada tais componentes, no sentido de produzir triglicérides e colesterol como fonte de energia. Para carrear este componente à circulação é necessário uma parte protéica para formar lipoproteínas.

Quando não há formação de lipoproteínas e ausência de cofatores como a colina pode ocorrer acumulo de gordura (esteatose) no fígado e posterior degeneração do hepatócito. (DIANZANI, 1976; LOMBARDI \& OLER, 1967).

As lâminas avaliadas não mostraram alteração degenerativa no núcleo dos hepatócitos; não havendo comprometimento do orgão.

Os rins avaliados não apresentaram nenhuma alteração patologica embora os rins do grupo 4 e 5 da tabela 11 
apresentaram percentualmente em relação ao peso do animal um valor maior em relação aos outros grupos (gráfico 6).

Na tabela 11 e gráficos 5 e 6 constam o peso do animal e do fígado em gramas e a relação percentual entre estes valores. 
TABELA 11 - Peso do fígado e do rim para um grupo de 6 animais

EXPERIMENTO 2: 10\% de proteína

\begin{tabular}{|c|c|c|c|c|c|c|c|}
\hline & \multirow{2}{*}{\multicolumn{2}{|c|}{ GRUPOS }} & \multicolumn{5}{|c|}{ PESO $(g)$} \\
\hline & & & ANIMAL & FIGADO & 8 & RIM & 8 \\
\hline 1 & caseína & $100 \%$ & 190,40 & $\begin{array}{r}14,71 \\
\pm \quad 1,47\end{array}$ & 7,73 & $\begin{array}{r}0,96 \\
+\quad 0,08\end{array}$ & 0,50 \\
\hline 2 & $\begin{array}{l}\text { caseína } \\
\text { colágeno }\end{array}$ & $\begin{array}{l}75 \% \\
25 \%\end{array}$ & 145,98 & $\begin{array}{r}9,55 \\
+\quad 0,40\end{array}$ & 6,54 & $\begin{array}{r}0,76 \\
\pm \quad 0,17\end{array}$ & 0,52 \\
\hline 3 & $\begin{array}{l}\text { caseína } \\
\text { colágeno }\end{array}$ & $\begin{array}{l}50 \% \\
50 \%\end{array}$ & 89,52 & $\begin{array}{ll} & 6,05 \\
\pm & 0,8\end{array}$ & 6,76 & $\begin{array}{r}0,45 \\
\pm \quad 0,09\end{array}$ & 0,50 \\
\hline 4 & $\begin{array}{l}\text { caseína } \\
\text { colágeno }\end{array}$ & $\begin{array}{l}35 \% \\
65 \%\end{array}$ & 62,76 & $\begin{array}{r}4,2 \\
\pm \quad 0,5\end{array}$ & 6,69 & $\begin{array}{r}0,43 \\
\pm \quad 0,06\end{array}$ & 0,69 \\
\hline 5 & $\begin{array}{l}\text { caseína } \\
\text { colágeno } \\
\text { prolina }\end{array}$ & $\begin{array}{r}35 \% \\
65 \% \\
1 \%\end{array}$ & 56,21 & $\begin{array}{r}3,5 \\
+\quad 0,4\end{array}$ & 6,23 & $\begin{array}{r}0,45 \\
\pm \quad 0,08\end{array}$ & 0,80 \\
\hline 6 & $\begin{array}{l}\text { caseína } \\
\text { colágeno } \\
\text { aa essenci }\end{array}$ & $\begin{array}{l}35 \% \\
56 \% \\
\text { iais* }\end{array}$ & 109,30 & $\begin{array}{r}7,9 \\
\pm \quad 0,5\end{array}$ & 7,23 & $\begin{array}{r}0,64 \\
\pm \quad 0,15\end{array}$ & 0,59 \\
\hline
\end{tabular}

* metionina 0,13 ; triptofano 0,7 ; tirosina 1,0 ; leucina 1,0 \% - porcentagem do peso do órgão em relação ao peso do animal. 
GRÁFICO 5- VARIAÇÃO PORCENTUAL DO PESO DO FIGADO (X10) OBTIDOS PARA OS GRUPOS REFERNTES AOS RESULTADOS DA TABELA 11.

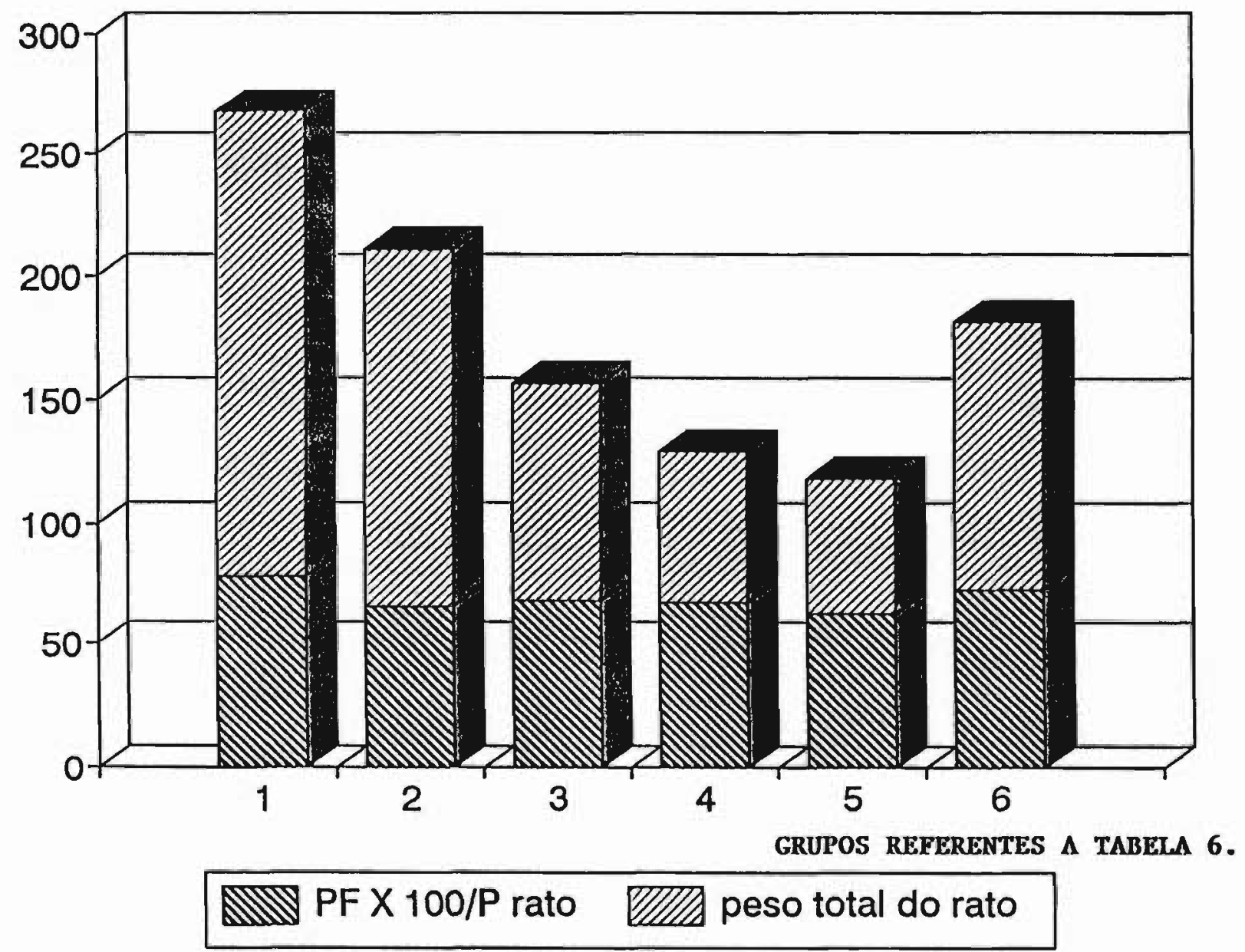

PF $=$ PESO DO RIGADO LM GRAMAS 
GRÁFICO 6- VARTAÇ̃̃o PORCENTUAL DO PESO DO RIM(X10) OBTIDOS PARA OS GRUPOS REFERENTES AOS RESULTADOS DA TABELA 11.

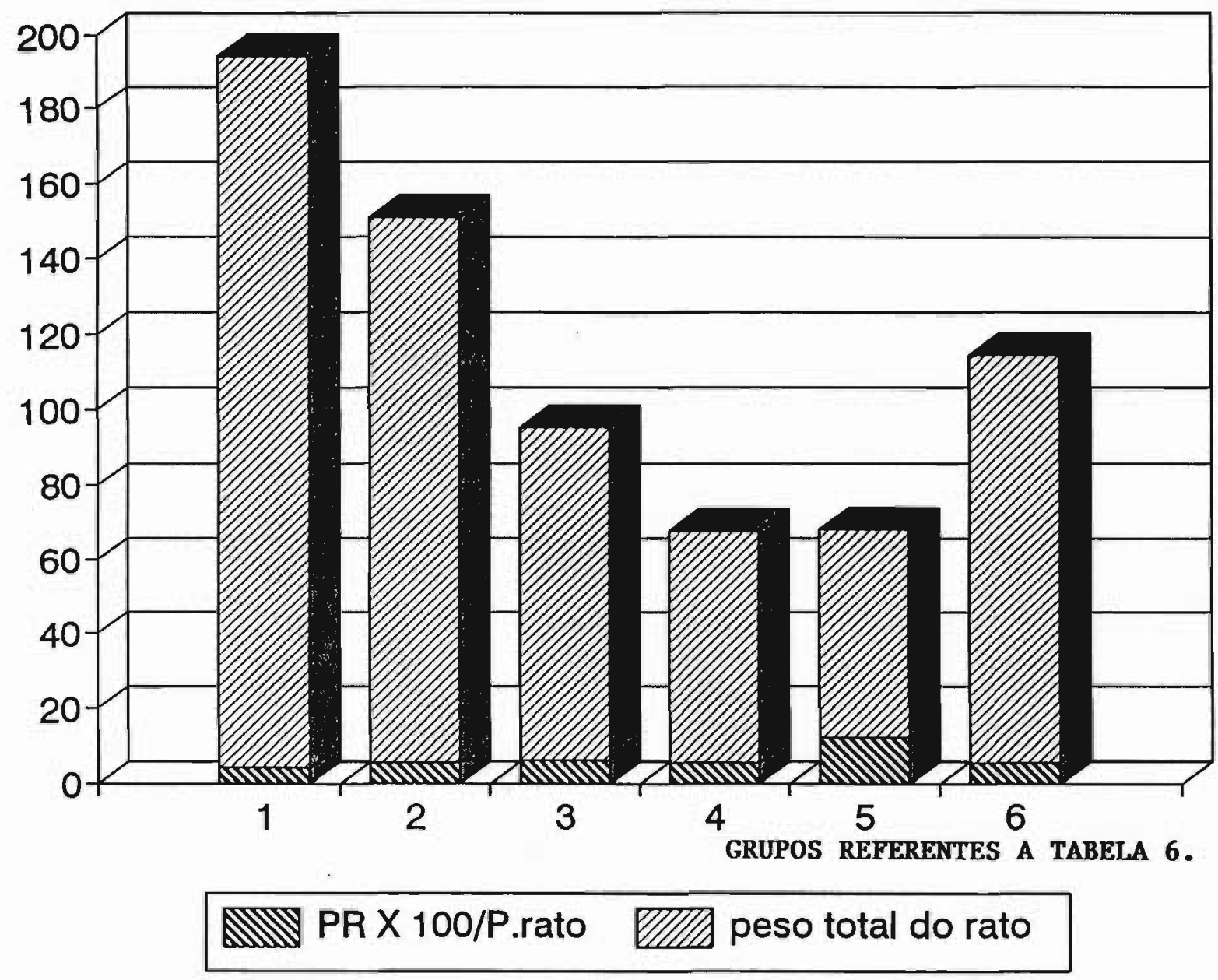

PR= PESO DO RIM EM GRAMAS 
Demonstrando não haver grande variação percentual em relação ao peso do animal nos diferentes grupos.

\section{5 - Avaliação histológica do tecido cutâneo}

Fotos em microscopia óptica foram feitos a partir do material de tecido cutâneo dos animais utilizados no experimento 2 com $10 \%$ de proteina (tabela 3) (figuras 1 a 6). A derme e a hipoderme representativas dos diferentes grupos foram medidas (em $\mathrm{cm}$ ) a partir das fotomicrografias apresentadas nas figuras 8 à 12. O valor do doseamento de hidroxiprolina em g/100g de pele seca constam das tabelas 12 e 13. Avaliando os resultados destas tabelas verificamos que o valor nutricional diminui com o acréscimo de colágeno à ração, bem como diminui a espessura da derme e hipoderme para os grupos 2,3 e 4 (figuras 9, 10 e 11). Porém notou-se que doseamento de hidroxiprolina não provocou alterações para os grupos 1 e 2 e apresentou aumento significativo para os grupos 3 e 4 .

A adição de 50 - 65\% de colágeno à ração, mostram um aumento de hidroxiprolina no tecido cutâneo e diminuição do tecido adiposo, com conseqüente da perda de peso do animal. Considerando os aminogramas das tabelas $4,5,6$ e 7 e os gráficos $4 \mathrm{~A}, 4 \mathrm{~B}, 4 \mathrm{D}$ e $4 \mathrm{~F}$ podemos concluir que a adição de colágeno acima de $25 \%$ promove um desequilíbrio no conteúdo de aa, com especial enfoque aos aminoácidos essenciais. 0 aminograma final não é suficiente para produzir energia no sentido de construir tecido, por este motivo o organismo utiliza a gordura como fonte de energia promovendo a diminuição do tecido adiposo. o acréscimo de hidroxiprolina no tecido pode 
demonstrar alterações no metabolismo do colágeno. Alterações estas provavelmente devido às ligações cruzadas entre as moléculas de colágeno tornando-as mais insoluvel e portanto menos disponivel ao pool metabolico proteico. Assim sendo o porcentual de hidroxiprolina se elevaria em relação ao tecido onde esta ocorrencia fosse mais pronunciada. Este é provavelmente um dos mecanismos metabolicos que justificaria o maior teor de HP obtido no doseamento de pele. A perda de peso do animal com esta dieta e manutenção dos niveis de colágeno na pele pois não ocorre a depleção facilmente faz com que a proporcionalidade do teor de colágeno aumente em relação ao tecido. Pelas figuras 10 e 11 verifica-se menor espessura da derme, porém nota-se um adensamento destas células sendo necessários estudos em microscopia eletrônica para verificar-se alterações em relação à estas estruturas.

Os resultados da tabela 13 em relação aos grupos 5 e 6 onde estão relacionadas na adição de $65 \%$ de colágeno com prolina (grupo 5) e com aminoácidos essenciais (grupo 6). Verificou-se que para o grupo 6 a adição de aminoácidos essenciais promoveu um balanceamento do aminograma elevando o peso do animal e conseqüentemente aumentando a espessura da camada adiposa. observou-se diminuição do teor de hidroxiprolina do conjuntivo em relação ao grupo controle (grupo 3) não ocorrendo adensamento de células.

No grupo 5, suplementado com $1 \frac{\%}{6}$ de prolina, houve queda no valor nutritivo da proteína e portanto uma diminuição no peso do animal; porém, a derme e hipoderme apresentaram-se espessas figura 12. O teor de hidroxiprolina diminuiu em relação ao padrão (grupo 3 ) . 
E importante ressaltar, que estes experimentos são apenas indicativos, pois foram avaliados somente para dois animais por grupo, sendo necessário que o número de amostras seja estatisticamente significativo para a confirmação dos resultados.

SAMS \& SMITH (1965) descrevem alterações histológica de colágeno na pele em função da idade. Demonstraram que o colágeno em pele de jovem é formado de delicadas fibras as quais se torman mais espessas com a idade.

LOEWI \& MEYER (1958) atribuem este espessamento da fibra de colageno em pele de adulto em contraste as fibras de embrião devido ao aumento de sulfato de dermatan em $64 \%$ enquanto este é encontrado em pequenas quantidades em pele de embrião. As fibras elásticas são inicialmente ausentes em pele prematura e facilmente identificadas em pele adulta.

observações em microscopia eletrônica revelam copiosa alteração no diâmetro da fibra de colágeno com a idade. As fibras em animais jovens apresentam menor diâmetro e desorganização na molécula de colágeno.

MACKENZIE et al. (1993) verificaram através de experimentos em crescimento e diferenciação de epitelio de rato que este é dependente de influências dérmicas em substrato de colágeno. Concluindo que fatores difusiveis de origem dérmica facilitam o crescimento e diferenciação.

KIRK et al. (1993) demonstraram em voluntarios humanos acima de 65 anos cujas dietas foram suplementadas com $30 \mathrm{~g}$ de aspartato de arginina e $17 \mathrm{~g}$ de arginina livre pelo 
período de duas semanas aumentou significativamente o teor de hidroxiprolina no tecido cicatricial e melhorou a resposta imune em idosos.

SASSAKI et al. (1993) estudaram células cutâneas de três pacientes com neurofibroma de fibroblasto e fibroblasto de quatro adultos saudáveis em meio de cultura. Determinou-se a sintese de DNA e de colágeno medindo a incorporação de timidina $3 \mathrm{H}$ e prolina $3 \mathrm{H}$ respectivamente. Os valores para cultura de células de neurofibroma aumentaram 54\% na sintese de DNA e 60\% na sintese de hidroxiprolina não dialisavel.

\section{6 - Comentário}

Em nosso trabalho observamos como ja demonstrado na literatura que o colágeno, é uma proteína pobre em relação ao valor biológico embora na associação até $28 \%$ não altera significativamente o valor biológico da proteína padrão a ele associada. Em relação a incorporação a pele verificamos que dietas contendo alto teor de colágeno demonstraram tendência para maior incorporação de hidroxiprolina na pele bem como uma diminuição da hipoderme fatores estes interessantes em caso de dieta para obeso e por período determinado.

o presente trabalho determina uma tendência do colágeno em relação a pele que será posteriormente avaliada de forma estatisticamente mais significativa através de determinação de hidroxiprolina na pele de rato em função da dieta oferecida aminograma plasmático e avaliação em microscopia eletronica do tecido cutâneo que nos permitira 
informações mais precisas dos processos biológicos ocorridos demonstrando uma especificidade nutricional do colágeno. 
TABELA 12 - Teor de hidroxiprolina em g/loog de pele seca e - peso do rato para dois animais de cada grupo de diferentes rações do experimento 2 com $(10 \%$ de proteína).

\begin{tabular}{|c|c|c|c|c|c|}
\hline $\begin{array}{l}\text { GRUPO } \\
\text { DE RAÇÕES }\end{array}$ & EM $\%$ & $\begin{array}{l}\text { PESO } \\
(g)\end{array}$ & $\begin{array}{l}N e \\
(*)\end{array}$ & TEOR I & $\begin{array}{l}\text { DE HIDROXIPROLINA } \\
\mathrm{g} / 100 \mathrm{~g}\end{array}$ \\
\hline$\stackrel{1}{\text { Caseina } 1}$ & 100 & $\begin{array}{l}182,5 \\
189,4\end{array}$ & $\begin{array}{l}2 \\
4\end{array}$ & $\begin{array}{l}3,30 \\
3,75 \\
4,01 \\
3,27 \\
4,15 \\
2,71\end{array}$ & $\begin{array}{l}\mathrm{MT}=3,54 \\
\mathrm{DPT}=0,55\end{array}$ \\
\hline \begin{tabular}{l}
\multicolumn{2}{c}{} \\
Caseína \\
Colágeno
\end{tabular} & $\begin{array}{l}75 \\
25\end{array}$ & $\begin{array}{l}160,2 \\
162,5\end{array}$ & $\begin{array}{l}9 \\
11\end{array}$ & $\begin{array}{l}3,97 \\
2,84 \\
3,32 \\
4,00 \\
4,65 \\
3,96\end{array}$ & $\begin{array}{l}\mathrm{MT}=3,79 \\
\mathrm{DPT}=0,47\end{array}$ \\
\hline \begin{tabular}{l}
\multicolumn{3}{c}{} \\
Caseína \\
Colágeno
\end{tabular} & $\begin{array}{l}50 \\
50\end{array}$ & $\begin{array}{l}90,4 \\
81,4\end{array}$ & $\begin{array}{l}15 \\
16\end{array}$ & $\begin{array}{l}4,69 \\
4,64 \\
5,01 \\
4,74 \\
3,14 \\
3,96\end{array}$ & $\begin{array}{l}\mathrm{MT}=4,37 \\
\mathrm{DPT}=0,50\end{array}$ \\
\hline \begin{tabular}{l}
\multicolumn{4}{c}{} \\
Caseína \\
Colageno
\end{tabular} & $\begin{array}{l}35 \\
65\end{array}$ & $\begin{array}{l}64,5 \\
56,5\end{array}$ & $\begin{array}{l}21 \\
23\end{array}$ & $\begin{array}{l}5,20 \\
5,05 \\
5,41 \\
5,01 \\
4,35 \\
4,91\end{array}$ & $\begin{array}{l}\mathrm{MT}=4,99 \\
\mathrm{DPT}=0,27\end{array}$ \\
\hline $\begin{array}{l}\quad \mathbf{5} \\
\text { Caseína } \\
\text { Colageno } \\
\text { Prolina }\end{array}$ & $\begin{array}{c}34,5 \\
64,5 \\
1\end{array}$ & 58,0 & $\begin{array}{l}28 \\
29\end{array}$ & $\begin{array}{l}2,60 \\
2,36 \\
2,97 \\
3,71 \\
3,65 \\
3,75\end{array}$ & $\begin{array}{l}\mathrm{MT}=3,17 \\
\mathrm{DPT}=0,18\end{array}$ \\
\hline $\begin{array}{l}\quad 6 \\
\text { Caseína } \\
\text { Colágeno } \\
\text { AA }\end{array}$ & $\begin{array}{r}33,6 \\
63,6 \\
2,4\end{array}$ & $\begin{array}{l}117,6 \\
115,4\end{array}$ & 33 & $\begin{array}{l}2,96 \\
3,20 \\
2,55 \\
3,86 \\
3,71 \\
4,76\end{array}$ & $\begin{array}{l}\mathrm{MT}=3,51 \\
\mathrm{DPT}=0,44\end{array}$ \\
\hline
\end{tabular}

MT e DPT=média das médias dos devios padrões.

*= número do rato no experimento 
TABELA 13 - Peso dos ratos (média de dois experimentos) teor de hidroxiprolina em $\mathrm{g} / 100 \mathrm{~g}$ de pele seca (média de seis experimentos) por grupo de ração oferecida.

\begin{tabular}{|c|c|c|c|c|}
\hline $\begin{array}{l}\text { GRUPOS } \\
\text { DE RAÇÃO EM \% }\end{array}$ & $\begin{array}{c}\text { PESO RATO } \\
\text { (gramas) }\end{array}$ & $\begin{array}{c}\text { ESPESSURA } \\
\text { DERME (cm) }\end{array}$ & $\begin{array}{c}\text { ESPESSURA } \\
\text { HD }(\mathrm{Cm})\end{array}$ & $\begin{array}{c}\text { HIDROXIPROLINA } \\
\text { g/100g }\end{array}$ \\
\hline 1 Caseína 100 & 185,9 & 4,0 & 2,5 & $3,53 \pm 0,55$ \\
\hline 2 Caseina 75 \\
Colágeno 25 & 161,4 & 3,0 & 1,0 & $3,46 \pm 0,52$ \\
\hline 3 Caseína 50 \\
Colágeno 50
\end{tabular}

HD $=$ Hipoderme

$A A=$ Aminoácidos essenciais (metionina, triptofano, tirosina e leucina) 
GRAFTCO 7 - HISTOGRAMA REFERENTE AOS DADOS DA TABELA 13. OS VALORES DO TEOR DE HIDROXIPROLINA ( EM GRAMAS POR 10OG DE PELE SECA) ESPESSURAS DA DERME IE HIPODERME (EM CM ) FORAM MULTIPLICADAS PELO FATOR 10 PARA UMA MELHOR VISUALIZAÇÃO DOS RESULTADOS.

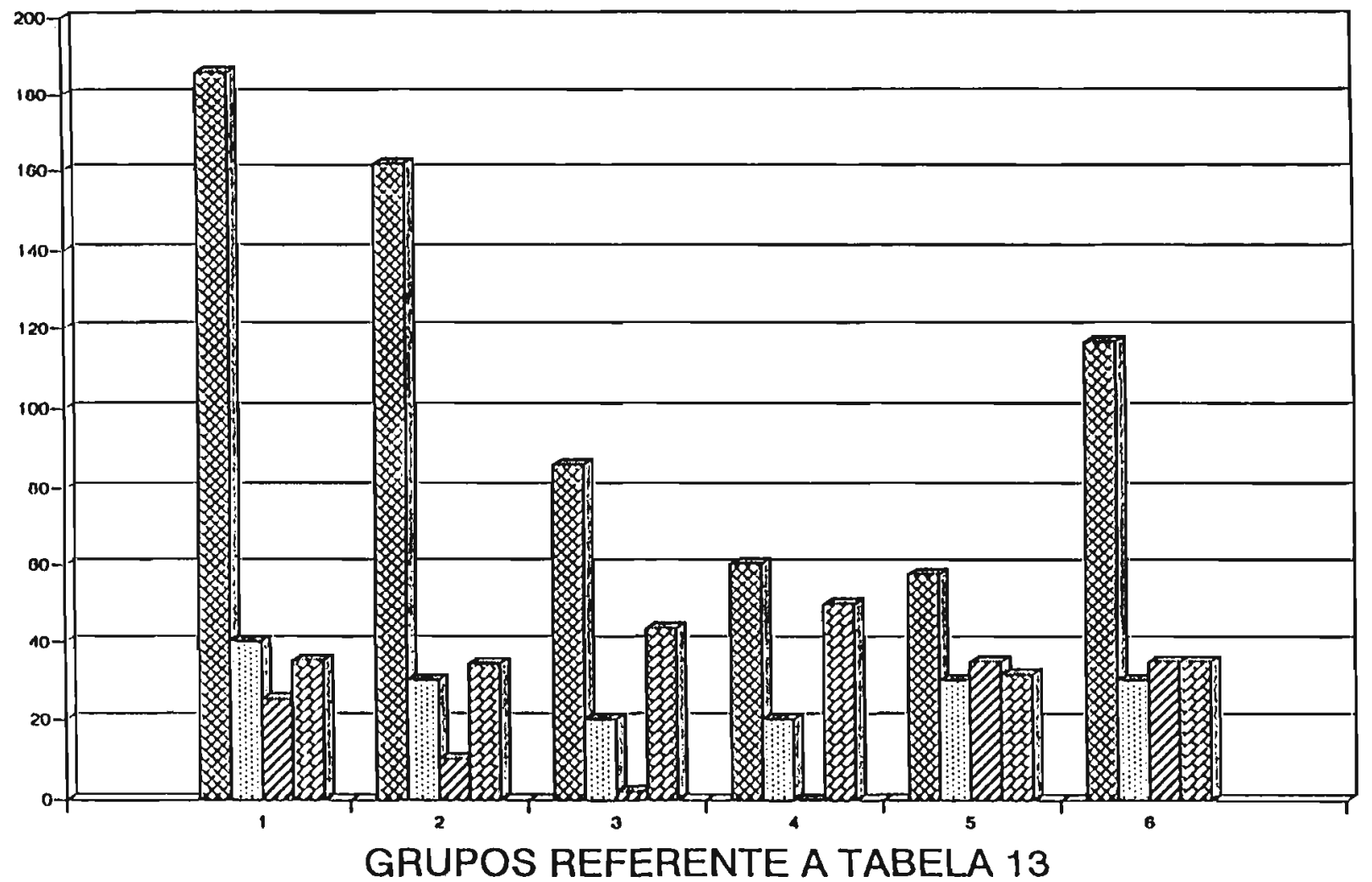




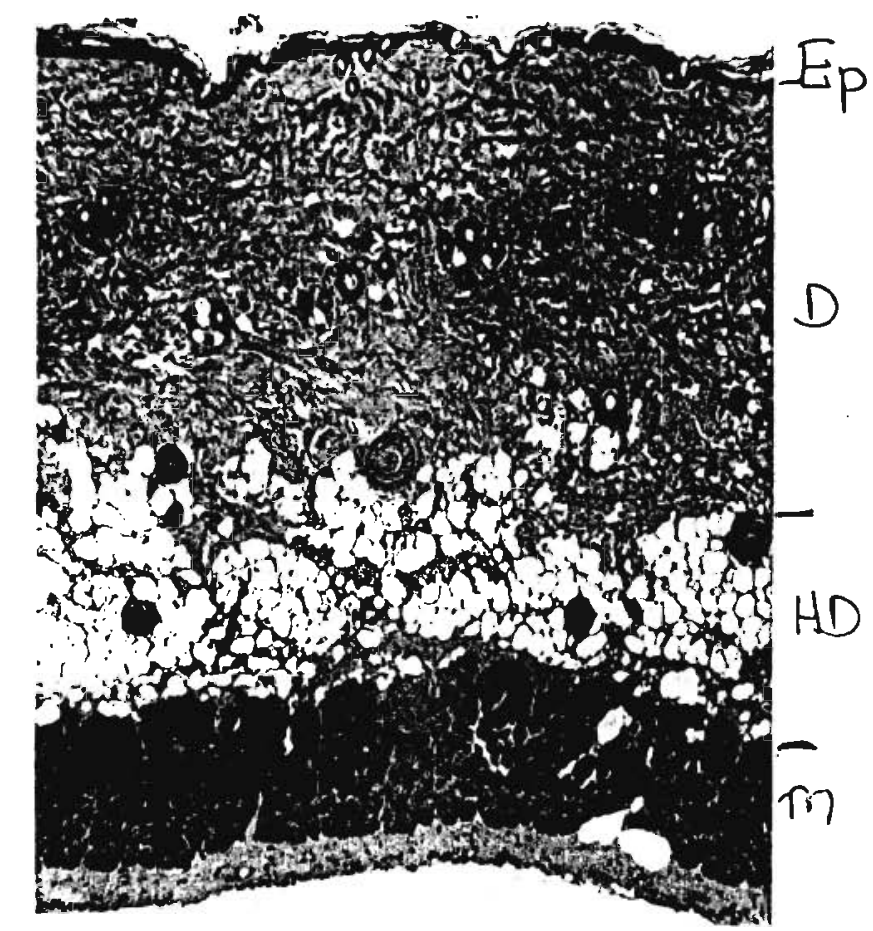

FIGURA 8- FOTOMIGROGRÁFIA EM CORTE TRANSVERSAL DE PELE COM 5 MICROMETROS DE ESPESSURA; AUMENTO 20X DO ANIMAL DO GRUPO 1 DA TABELA 12

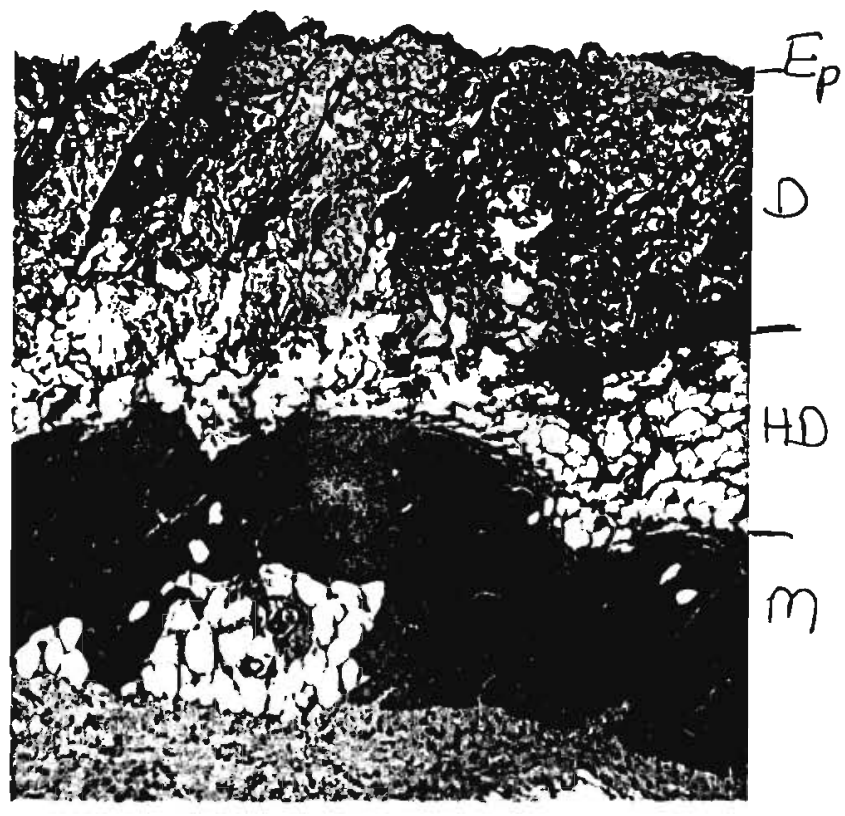

FIGURA 9- FOTOMICRO CRÁFIA EM CORTE TRANSVERSAL DE PELE COM 5 MICROMETROS DE ESPESSURA ,AUMENTO 20X, DO ANIMAL DO GRUPO 2 DA TABELLA 12

$$
\text { EP = EPIDERME D } \quad \text { DERME IID }=\text { HIPODERME M= MUSCULO }
$$




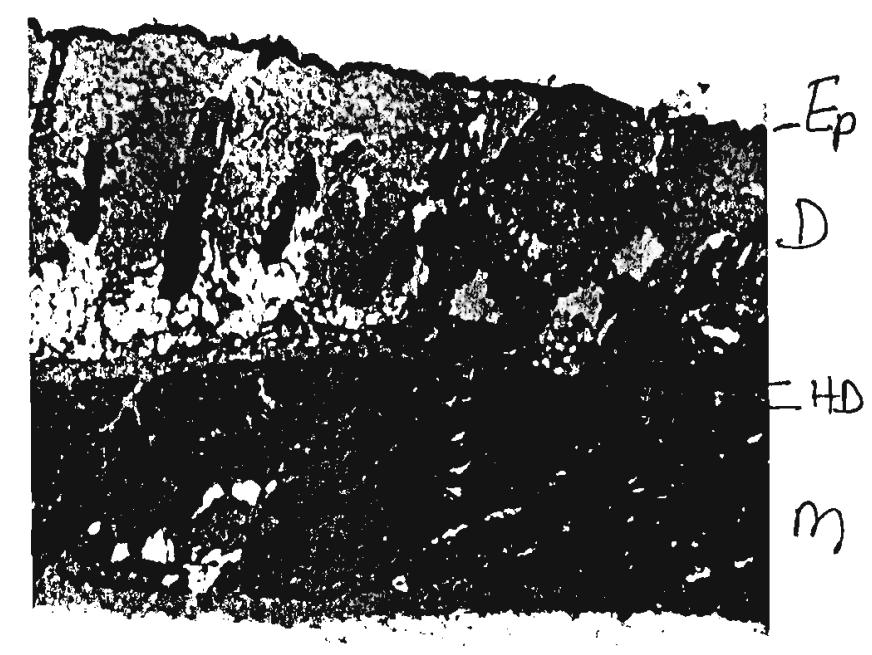

FIGURA 10- FOTOMICROGRAFIA EM CORTE TRANSVERSAL DE PELE COM 5 MICROMETROS DE ESPESSURA, AUMENTO 20X DO ANIMAL DO GRUPO 3 DA TABELA 12

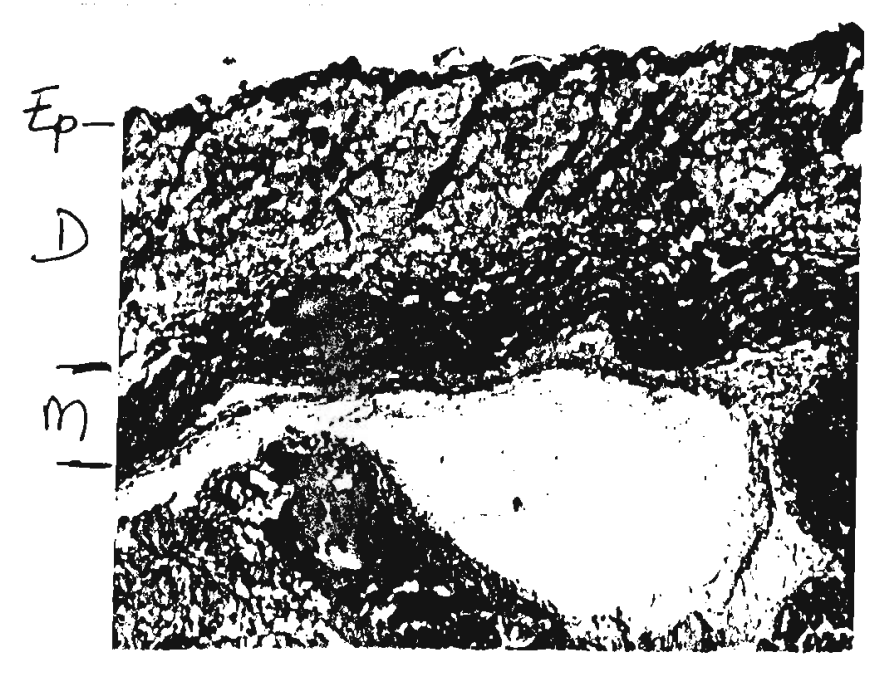

FIGURA 11- FOTOMTCROGÁFIA EM CORTE TRANSVERSAL DE PELE COM 5 MTCROMETROS DE ESPESSURA, AUMENTO 2OX DO ANTMAL DO GRUPO 4 DA TABELA 12

$$
\text { EP }=\text { EPIDERME } \quad \mathrm{D}=\text { DERME } \quad H D=\text { HIPODERME } \quad M=\text { MUSCULO }
$$




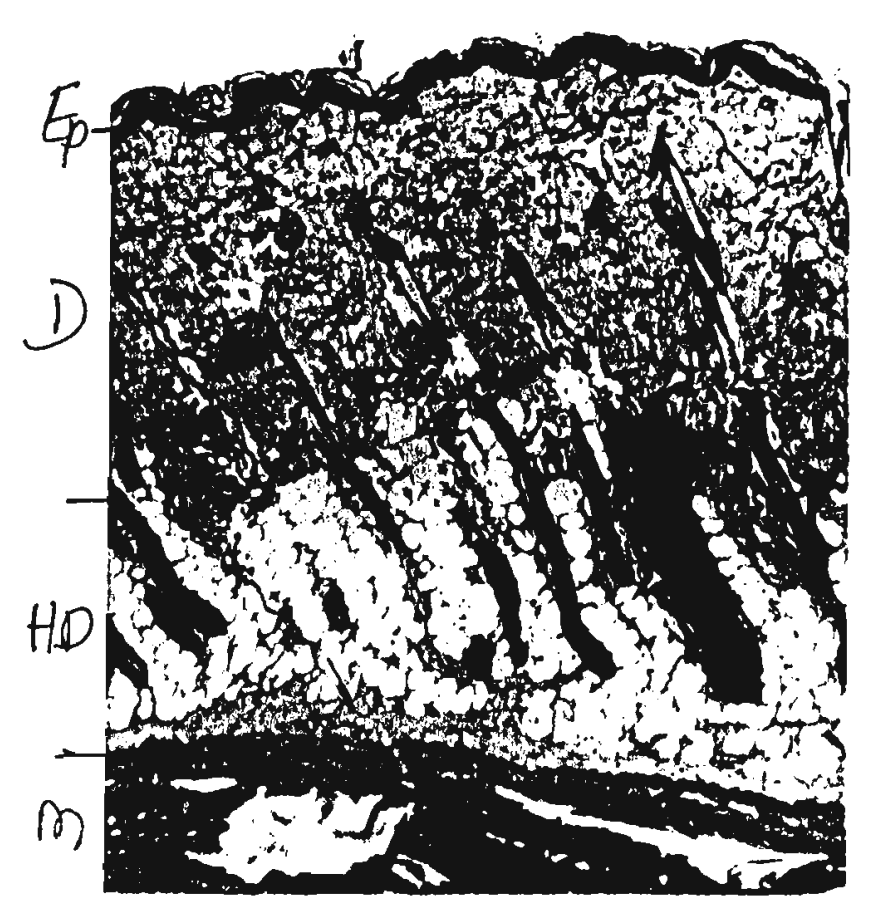

FIGURA 12- FOTOMICROGRKFIA EM CORTE TRANSVERSAL. DE PELE COM 5 MICROMIETROS DE ESPESSURA, AUMENTO 20X DO ANIMAI. DO GRUPO 5 DA TABETA 12

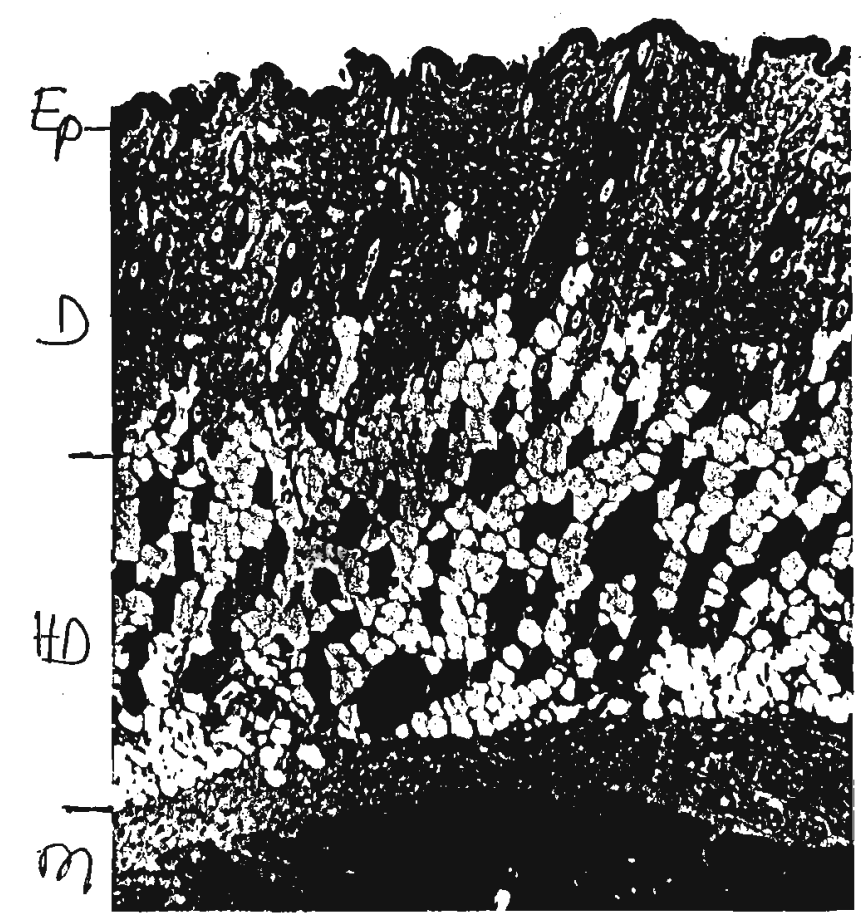

FIGURA 13- FOTOMICROGRXFIA EM CORTE TRANSVERSAL DE PELE COM 5 MICROMETROS DE ESPESSURA, AUMENTO 20X DO ANIMAL, DO GRUPO 6 DA TABELA 12

$$
\text { EP = EPIDERME } D=\text { DERME } \quad \mathrm{IID}=\text { HITODERME } \quad M=\text { MUSCULO }
$$




\section{7 - CONCLUSÃO}

7.1 - o colágeno hidrolisado a partir de pele bovina incorporado a $25 \%$ em dieta de caseína não promove alteração significativa do valor biológico da ração.

7.2 - A adição de prolina na fonte de colágeno em animais em crescimento apresentou-se não limitante quando adicionada a 25\% de colágeno e limitante quando adicionada a 65\% de colágeno.

7.3 - Dieta baseada unicamente em colágeno comportase como aprotéica.

7.4 - A adição de colágeno à ração em niveis variados não promove alterações patológicas em fígado no período de 28 dias.

7.5 - Adições de colágeno acima de $50 \%$ à ração diminuem a hipoderme aumentando o teor de hidroxiprolina doseada na pele e diminuindo o valor biológico. A diminuição da hipoderme, ou seja, tecido adiposo sugere interesse neste tipo da alimentação em dieta para controle de peso. 


\section{8 -}

Estudou-se a adição de hidrolisado de colágeno à rações com caseína nas proporções de $0 \%, 25 \%, 50 \%, 65 \%, 75 \%$ e $100 \%$

As rações com $25 \%$ e $65 \%$ de hidrolisado protéico foram acrescidas com prolina e aminoacidos essenciais (tirosina, triptofano, metionina e leucina).

As rações continham $10 \%$ e $20 \%$ de proteína. Determinou-se o coeficiente de eficácia protéica, coeficiente de digestibilidade, composição centesimal, aminograma e avaliou-se histológicamente o fígado e rim e a pele. Doseou-se - teor de hidroxiprolina da pele dos animais testados.

Verificou-se que: a adição de $25 \%$ de hidrolisado de colágeno à caseína não promoveu modificação significativa no valor biológico da ração. A adição de prolina em ração com 25\% de colágeno para ratos em crescimento não demonstrou alteração do peso dos animais. Entretanto com adição de $65 \%$ de colágeno houve queda no peso dos animais em relação ao controle.

- fígado dos animais estudados (quando utilizadas raçōes com $10 \%$ de proteína), não demonstrou alteração significativa em relação às diferentes adições de colágeno. Quando a ração foi acrescida de $50 \%$ e $65 \%$ de hidrolisado de colágeno, o doseamento de hidroxiprolina na pele aumentou e os cortes histológicos de tecido cutâneo apresentaram ausência de hipoderme. 


\section{9 - SUMMARY}

We studied hidrolised collagen in association with casein at the proportions of $0 \%, 25 \%, 50 \%, 65 \%, 75 \%$ and $100 \%$.

We concluded that $25 \%$ addition of collagen, do not change significantly nutritional value. Higher additions in hidrolised collagen, on diets, demostrated higher content of hidroxiproline and lower in adipose tissue in cutaneous tissue. 


\section{0 - REFERÊNCIAS BIBLIOGRÁFICAS *}

ALLISON, J.B. Biological evaluation of proteins. Physiol. Rev., Bethesda, v.35, p.664-668, 1955.

ANITA, L.R., FAVRIANSSANM, S. In vivo digestibility of insoluble collagen from bovine tendon as influenced by the inhibition of gastric acid secretion. J.Food.Sci., Chicago, v.50, p.1523-1524, 1985 .

AREAS, A.G. Effect of lipid protein interaction on hydration characteristics of detatted oftal protein isolates. J.Food.Sci., Chicago, v.51, p.880-882, 1986.

AREAS, A.G., LAWRIE, R.A Effect of lipid-protein interaction on extrusion of oftal protein isolates Meat Sci., Banking, v.11, p.275-299, 1984 .

ASGHAR, A. \& YATES, N.T.M., Muscle characteristics and meat quality oflambs grown on different nutritional planes II. Chemical and biochemical effects. Agric. Biol. Chem., Tokyo, v.43, p.437-41, 1979 .

ASGHAR, A.\& HENRICKSON, R.L., Chemical Biochemical and nutritional characteristics of collagen in food systens. Adv. Food Res. V.28 New York, p.231-372, 1982. 
ASGHAR, A. SAMEJIMA, K., YASIN, T., Chemical, biochemical and nutricional characteristics of collagen in food system CRC Crit. Rev. Food Nutr., Tokyo, v.22, p.27-106, 1985.

ASHLEY, J.H., FISHER, H., The amino acids deficiency of gelatin for the growing chicken Poult.Sci., Ithaca, v.45, p.541, 1966.

ATKINSON, J.L. Substrate utilization and fasting metabolism during post natal development of the pig. Tese Doutoramento - University of Guelph. 1977.

BABJI, A.S., FRONING, G.W., SATTERLEE, L.D. Protein nutricional quality of mechanically deboned poultry as predict by the cPER assay. J.Food.Sci., Chicago, v.45, p.441-443, 1980.

BAILEY, A.J. Recent advances in the chemistry of meat. London: Royal Society of Chemistry, 1983. 245p

BALL, R.O., ATKINSON, J.L., BAYLEY, H.S. Proline as an assential amino acids for young pig Br.J.Nutr., Cambridge, v. 55 p. $659-668,1986$.

BARKER, D.H. Advances in nutritional research V1 Draper H.H. editor New York, 81-92, 1977 .

BATTISTA, O.A. Microcrystal polymer science, New York: Mac Grow-Hill 1975. p.58 
BEN-GERA, I., KRAMER, A. The utilization of food industries wastes Adv. Food Res., New York, v.17, p.77-152, 1969.

BENDER, A.E., ZIA, M. Meat quality and protein quality. J. Food Technol., Oxford, v.11, p.495, 1976.

BENGTSSON, S.G. Serum free amino acids in piglets during the early post natal period J.Animal Sci., Albany, v.32, p.879$882,1971$.

BENGTSSON, S.G. Sow colostral free amino acids and their importance for the newborn piglet Acta Vet. Scand., Copenhagen, v.13, p.7-13, 1972 .

BENGTSSON, S.G., HAKKARAINEN, R.V.J. Distribution in piglet after administration of 14 CL proline as studied by whole body autoradiography and impulse counting, J.Animal Sci., Albany, v.41, p.106-112, 1975.

BERK, K, Protein systems in food In: BRAVERMAN S. Introduction to the biochemistry of foods. Amsterdam: Elsevier, 1976, p. 61-77.

BEUTLER, E. Glucose 6-phosphate dehydrogenase deficiency. In The Metabolic Basis of Inherited Disease, 3rd ed., J.B. Stanbury, J.B. Wyngaarden, and D.S. Fredrickson, Eds. McGraw-Hill, Nova York, p.1358, 1972. 
BHANDARI, V.K. Pharmaceutical grade gelatin manufacture. Cast Pharm., 21, 21-23, 1978.

BODWELL, C.E. Advances in meat research V4. Colagen as food AM PERSON, T.R.; DUTSON, A.J.; BAYLEY ed. New York, pg.382, 1987 .

BODWELL, C.E. Problems in the development and application of rapid methods of assessing protein quality food Technol., Chicago, v.31, p.73-77, 1977 .

BODWELL, C.E., ANDERSON, B.A. Nutritional composition and value of meat and products. In Muscle As a Food. Bechtel (Ed.) Academic Press New York., 1986, p.345.

BORSOOK, H.; KEIGHLEY, G.L. Continuing, metabolism of nitrogen in animals. Proc. Roy. Soc., London, v.118, p.488$491,1935$.

BOSE, S.M. The distribution nature and linking of sialic acid in skin protein., Biochim. Biophys. Acta, Amstedan, v.74, p. 265-67, 1963 .

BOWES, J.H., ELLIOTT, R.D., MOSS, J.A. The composition of collagen and acid soluble collagen of bovine sken Biochem. J.,Colchester, v.61, p.143-146, 1955. 
BOWES, J.H., RAISTRICK, A.S. The influence of clerent trends in livestock production on the composition and leather making properties of trides and skin. J.Am. Leather Chem. Assoc., v.63, p.192-194, 1968 .

BRANT, W. North-South, a program of Survival, London : Pan Books ed. $1980,470 p$.

BREUER, Jr., J.H., Jr., POND, W.G., WARNER, G.R. e LOOSLI, J.K. The role of dispensable amino acids in the nutrition of the rat. J. Nutr., Philadelphia, v.82, p.499-501, 1964.

BURGESON, R.E., HOLLISTER, W. Collagen heterogeneity in human cartilage: Identification of several new collagen chain Biochem Biophys Res Commun, New York, v.87, p.124-31, 1979.

BYERLY, T.C. Competition between animal and men for agricultural resource. In: ALTSHUL, A.H., WILCKE, H.L. New protein foods, New York: Academic Press, 197, pt.A, p.73116,1978 .

CANHOS, D.A., DIAS, E,L. Tecnologia de carne bovina e produtos derivados. São Paulo: Fundação Tropical de Pesquisa e Tecnologia; Secretaria da Industria Comercio e Tecnologia, $1982,440 p$. 
CHAPMAN, D.C., CASTILLO, R., CAMPBELL, J.A. Evaluation of proteins in food. A method for the determination of protein efficiency ratio. Can,J. Biochem. Physiol., ottawa, v.37, p.679-681, 1959 .

CHEFTEL, J.C., CHEFTEL, H. Introduccion a la bioquimica de los alimentos. Zaragoza: Acribia, 1976, p.43-63.

CHVAPIL, M., KRONENTHAL, R.L., VAN WINKLE, Jr. W. Medical and surgical application of collagen. Int. Rev. Connect. Tisue Res., New York, v.69, p.280-285, 1973.

CIFONELLI, J.A., RODEN, L. The isolation of heparitin sulfate from hog skin. Biochim Biophys. Acta, Amsterdam, v.165, p. 553-558, 1968 .

COMMITTEE ON LABORATORY ANIMAL DIETS / ASSEMBLY OF LIFE SCIENCE NATIONAL RESEARCH COUNCIL, Control of diets in laboratory animal experimentation Nutr. Abstr. Rev., Slough, v.49, p. 413-419, 1979 .

COOPER, D.R., JOJMSON, P., The soluble, protein of bovine hide II Extract ion by aqueous sodium phosphate and halfsaturated time. Biochim Biophys. Acta, Amsterdam, v.30, p.590-, 1958 .

COOPER, D.R., RUSSEL, A.E., DAVISON, R.T. The soluble protein of skin, J. Am. Leather Chem. Assoc., v.62, p.423-425, 1967. 
CoX, R.J. Photographic gelatin New York: Academic Press, 1972, $250 p$.

CUNHA, T.J. Land animals: opportunities for improved production In: ALTSHUT, A. M., WILCKE, H. L. New protein food, New York: Academic Press, 1978, Pt.A, p.198-225.

CUPERLOUVIC, M. Free amino acids in the blood plasma of newborn piglet before and after changes in sow colostrum. Acta Vet. Scand., Copenhagen, v.8, p.217-227, 1967.

CURTS, A. Uses of collagen in edible products In: WARD, A.G., COURTS, A., eds. Science and technology of gelatin. New York: Academic Press, 1977, 396p.

DIANZANI, M.U. Toxic liver injury by protein synthesis inhibitor In Popper, H. and Schallner, F. eds Progress in liver disease, New York, v.5, p.232-245, 1976.

DOVER, M.J., TALBOT, L.M. To feed the earth: agroecology for sustainable development. Washington: Word Resourses Institute $1987,578 \mathrm{p}$.

EFRON, M.L. Letter to the editor N. Eng. J. Med., Boston, v.17, p. 277-281, 1956 . 
EFRON, M.L., BIXBY, E.M. and PRYLES, C.V. Hydroxyprolinemia. II. A rate metabolic disease due to a deficiency of the enzyme "hydroxyproline oxidase" N. Engl. J. Med., Boston, v.272, p.1299-1304, 1965.

ELIAS, S., KOMANOWSKY, M., SINNAMON., H., ACETO, N.C. Converts collagen to food additives. Food Eng., Radnor, v.42, n.11, p.125-129, 1970 .

ELLIOT, R.F., VANDER NOOT, G.W., GILBREATH, R.E, FISHER, H. Effect of dietary protein level on composition changes in sow colostrum J.Animal Sci, v.32, p.1128-1137, 1971.

ERBRADABLER， V.H., PFAIFFER， G., WELLHAUSER， R. , ZUCKER, H. Effect of high collagen content in food and the development and deposition of connective tissue in the growing rat Z.Ernaehrungswiss, v.10, p.25-31, 1970 .

FAO/WHO Protein requirements, Genebra: World Health organization, 1965, Technical Report Series, n.301.

FOLIN, O.A. A theory of protein metabolins. Am. Physiol. Bethesda, v.13, p.117-119, 1986.

FORBES, R.M.; COOPER, A.R. and MITCHELL, H.H. The composition of the adult human body as determined by chemical analysis. J. Biol. Chem., Baltimore, v.203, p.359, 1953.

FRIBERG, S. Food emulsion New York: Marcel Dekker, 1976, 480p. 
FRIEDMAN, M., Inhibition of lysinoalanine synthesis by protein acylation In: FRIEDMAN, M., ed Nutritional improvement of food and feed proteins , New York., Pleneim, 1978, 750p.

FRIEDMAN, M. ZAHNLEY, J.C., MASTERS, P.M. Relationship between in vivo digestibility of casein and its content of lysinoalanine and D-amin acid. J. Food Sci. Chicago, V.46, p.127-133, 1981 .

GAULL, G.E., RASSIN, D.K., RAIHA, N.C.R., HEINODEN, K. Milk protein quantity and quality in low-birthweight infants. III. Efects on sulfur amino acids in plasma and urine. J. Pediatr., St.Louis, v.90, p.348-355, 1977.

GHADIMI, H., PECORA, P. Plasma amino acids after birth Pediatrics, Evanston, v.34, p.182-191, 1964 .

GHADIMI, H. Total parenteral nutrition New York: John wiley, $1975,316 \mathrm{p}$.

GOTLHÖFFER, N.R., Hidroxiproline content of meat cryslake, Illinois: In: HEGEDUS, I., BOKORI, J., eds. Gelatin in nutrition and medicine. 1945. p.162-180.

GRABER, G., BAKER, D.H. The essential nature of glycine and proline for growing chicken poultry Sci., Ithaca, v.52, p.892-896, 1973 . 
GREENE, D.E., SCOTT, H.M., JOHNSON, B.C. The role of proline and certain non essential amino acids in nutrition poutry Sci. v.41, p.116-220, 1962.

GRENWOOD. O. J. Plant nutrition and human welfare the world scene. J, Sci, Food Agric,, London; v.48, p.387-410, 1989.

HACKLER, L.R. In vitro indices. Relationship to estimate protein value for the human. In: BADWELL, C.E., ed. Evaluation of proteins for humans. Westport: 1977a, pg.119.

HACKLER, L.R. Methods of measuring protein quality A review of bioassay procedures. Cereal Chem., st. Paul, v.54, p.984-, $1977 \mathrm{~b}$.

HAGSTED, D.N. Assessment of protein quality in improvement of protein nutritive. Food and Nutrition Board. Natl. Acad. Sci. Natl. Res. Council Washington, 1974, 64p.

HANSON, J. and LOWY, J. Distribution of myosin and actin in myofibrils In Biochemistry of Muscle Contraction, $\underline{\mathrm{J}}$ Gergely, Ed. Little, Brown, Boston, p.141, 1964.

HARKNESS, M.L.R.; HAKNESS, R.D. The effect of a protein free diet on the collagen content on mice. J. Physiol., London, v.144, p.307-310, 1958 .

HARKNESS, R.D. Biological functions of collagen. Biol. Rev., New York, v.36, p.399-402, 1961. 
HARPER, A.E. Dispensable and indispensable amino acid interrelationships. In: BLACKBURN, G.L., GRANT, J.P., YOUNG, V.R., eds Amino acids: metabolism and medical applications. Littleton: PSG, 1983. p.105-121.

HENDRICKS, D.G., MAHONEY, A.W., GILLETT, T.A. Influence of removing connective tissue cooking and nitrite ceering on the protein quality of beef slank muscle. J. Food Sci., Oxford, v.42, p.186-189, 1977 .

HENRICKSON, R.L., RANGANAYAKI, M.D ASGHAR, A. Age species breed, sex and nutrition effect on hide collagen, CRC Crit. Rev.Food Sci. Techenol., Cleveland, v.20, p.159-72, 1982.

HERBERT, J.D.; COULSON, R.A. and HERNANDES, T. Free amino acids in the caiman and rat. Comp. Biochem. Physiol., oxford, v.17, p.583, 1966 .

HERMANSSON, A. Protein functionality and its relation to food microstructure Qualitas Plant. Plant Foods Human Nutr., The Hagne, v.32, p.369-388, 1983.

HIGHBERGER, J.H., STECKER, H.C. The chemical action of saturated lime solution on collagen. J.Am. Leather Chem. Assoc. $36,368,1941$.

HOPPER, A.F.; ROSE, P.M.; and WANNEMACHER, R.W., Jr.; Cell population changes in the intestinal mucosa of protein- 
depleted or starved rats. II. Changes in cellular migration rates. J. Cell Biol., New York, v.53, p.225, 1972.

HOPPICH, M.L., WITMORE, R.A., FEARHELLER, S. Composition and protein efficiency ratio of partially chopped beef and partially defatted beef fatty tissue and combination with selected protein. J. Food Sci.., Chicago, v.40, p.35-39, 1975.

HUMPHREY, J.H., NEWLERG, A., PERKINS, D.J. The detection and estimation of plasma albumina in rat and rabbit skin. Biochem. J., Colchester, v.64, 1956.

HUMPHREY, J.H., NEWBURG, A., PERKINS, D.J. Observation of the presence of plasma protein in skin and tendon. Biochem. J., Colchester, v.66, p.390-, 1957.

IDSON, B., BRASWELL, E. Gelatin Adv. Food Res. 7, 235, 1957.

INSTITUTO ADOLFO LUTZ - Normas analiticas do Instituto Adolfo Lutz: métodos quimicos e fisicos para análise de alimentos 2.ed., São Paulo, 1976, v.1, p.19-37.

INSTITUTO ADOLFO LUTZ - Normas analiticas do Instituto Adolfo Lutz, 3.ed., São Paulo, 1985, v.6.

JEWELL, D.K., KENDRICK, J.G., SATTERLEE, L.D. The DC-PER assay: a method for predicting protein qualit solely from amino acids composition data. Nutr. Rep. Int., Los Altos, v.21, p.25-38, 1980 . 
JUERGENS, P., DOLIF, D. Die Bedeutung nichtessentieller Aminosauren fur den stickstoffhaushalt des Menschen unter parentaraler Ernahrung, Klin. Wochenschr., v.46, p.131-, 1968 .

JUERGENS, P., DOLIF, D. Experimental results of parenteral nutrition with amino acids. In: WILKISON, A.W., ed. Parenteral Nutrition. Baltimore: Williams \& Wilkins, 1972, $485 p$.

JUNQUEIRA L.C., CARNEIRO J., Histologia basica 8 . ed. Rio de Janeiro: Guanabara Koogan, 1994, 388p.

KARMAS, E. Processed meat technology. Washington: Library of Congress, $1976,449 p$

KENZIE, H. Milk proteins chemistry and molecular biology VII, New York: Academic Press, 1971, p.139-162.

KINO, K., OKUMURA, J.I. Improvement of body weight and nitrogen balances of chicks fed histidine free or lysine free diets with supplementation of graded levels of sulfor containing amino acids. Poltry Sci., Ithaca, v.65, p.1736-1740, 1986a.

KINO, K., OKUMURA, J.I. The effect of single essential amino acid deprevation on chick growth and nitrogen and energy balances at amino acid libitune and equalized. Food Intakes Poultry Sci., Ithaca, v.65, p.1728-1735, $1986 \mathrm{~b}$. 
KINSELLA, J.E. Texturized protein fabrication, flavoring, and nutrition CRC Crit. Rev. Food Sci. Nutr., Cleveland, v.10, p.147-207, 1978 .

KINSELLA, J.E. Function properties to soy protein. J.Am. Oil Chem. Soc., Chicago, v.56, p.242-258, 1979.

KIRK, S.J., HURSON, M., REGAN,M.C., HOLT,D.R., WASSERKRUG, H.L., BARBUL, A., Arginina stimulate wound healing and immune function in elderly human beings. Surqery, Baltimore, v.114 p.155-9, 1993 .

KOCHAKIAN, C.C.; BARTLETT, M.N.; and MOE, J. Effect of high protein and hight carbohydrate diests on arginase and phosphatases of liver and kidney of normal and adrenalectomized rat. Am. J. Physiol., Bethesda, v.154, p. 489,1948 .

KOFOED, J.A., BOZZINI, C.E. Differential effect of hypophysectomey on skin and tracheal cartilage glycosamino glycans. Experientia, Basel, v.25, p.23-, 1969.

KOMANOWSKY, M., SINNAMON, H.I., ELIAS, S., HEILAND, W.K., ACETO, N.C. Production of comminuted collagen, for novel application. J. Am. Leather Chem. Assoc., v.69, p.410-418, 1071 
KOPPLE, J.D., SWENDSEID, M.E. Evidence that histidine is an essential amino acid in normal and chronically uremic man. J.Clin. Invest., New York, v.55, p.881-891, 1975.

KUEHL, W.M. and ADELSTEIN, R.S. The absence of 3Methylhistidine in red, cardiac and fetal myosins. Biochem. Biophys. Res. Commum., New York, v.39, p.956-960, 1970.

KUHN, K. The classical collagens types $I$, II and III. In: MAYNE, R., BURGESON, R.E., eds. Structure and function of collagen types biology of extracellular matrix: a series Academic Press, 1987, p.1-42.

LACY, J.M., WILMORE, D.W. Bovine collagen Nutr. Rev., New York, v.48, p. $48-57,1990$.

LAWRIE, R.A. Development in meat science, p.299, 1981.

LAWRIE, R.A. Meat science 4.ed. Washington: Pergamon, 1985, $267 \mathrm{p}$.

LEE, Y., ELLIOTT, J.G., RICKNSRUD, D.A., HADGERG, E.C. Predicting protein efficiency ratio by the chemical determination of connective tissue content in meat. J. Food Sci., Chicago, v.43, p.1359-, 1978.

LIPKIN, M. Cell proliferation in the gastrointestinal tract of man. Fed. Proc., Washington, v.24, p.10-15, 1965. 
LOEWI, G. \& MEYER, K. , The acid mucopolysaccharides of embrionic skin. Biochim. Biophys. Acta, New York, V. 27 P. 458-61, 1958 .

LOMBARDI, B., OLER, A. Choline deficiency fatly liver. Protein synthesis and release Lab. Invest., v.17, p.308-321, 1967.

LUBERT, S. Biochemistry 3.ed. New York: WH Freeman, 1988, 262p.

LUSK, G. The Science of Nutrition, 4 th ed. Saunders, Philadelphia, 1928, 158p.

MACKENZIE, I., RITTMAN, G., BREITKEUTZ, D., FUSENIG, N.E., Influence of connective tissue on the in vivo grow differentiation of murine epidermis. Epit. Cell Biol., Huston, v.2, p.107-19, 1993.

MARTINEZ, W.H. Functionality of vegetable protein other than soy J. Am. Oil Chem. Soc., Chicago, v.56, p.280-284, 1979.

MASTER, P.M., FRIEDMAN, M. Racemization of amino acids in alkali-treated food proteins. J. Agric. Food Chem., Easton, v.27, p.507-, 1979 .

MASTER, P.M., FRIEDMAN, M. Amino acids racemization in alkalitreated food proteins chemistry, toxicology and nutritional consequeces. ACS Symp. Ser 123, 165, 1980. 
MEIKLEHAM, V.; WELLS, I.C.; RICHERT, D.A.; and WESTERFELD, W.W. Liver esterase and xanthine oxidase during protein depletion. J. Biol. Chem., Baltimore, v.192, p.651, 1951.

MEISTER, A. Biochemistry of the amino acids New York: Academic Press, 1965, v.1, 465p.

MELLON, E.F., VIOLA, S.J., NAGHSKI, J. Stratigraphic distribuition of carbohydrate hexosamine and hidroxiproline in cattlehides. J. Am. Leather Chem. Assoc., v.55, p.622$635,1960$.

MEYER, K., HOFFMAN, P., SINKER, A. In: TUNBRIDGE, R.E., ed. Connective tissue oxford: Blackwell, 1957, p.80.

MILLER, E.J. The structure of fibril forming collagens Ann. Acad. Sci., New York, v.460, p.1-13, 1985.

MINOR, R.R. Collagen metabolism An I Pathol, New York, v.98, p. 226-280, 1980 .

MITCHELL, H.H., BLOCK, R.J. Some relationship between the amino acid contents of proteins and their nutrition value for the rat. J. Biol. Chem., Baltimore, v.163, p.599-620, 1946.

MONTANA, W., BENTLEY, J.P., DOBSON, R. Structure and skin composition. Adv. Biol. Skin,. New York, v.10, p.1-37, 1970. 
MUNRO, H.N. Basic concepts in the use of amino acids and protein hydrolysates for parenteral nutrition. AMA Symposium on Total Parenteral Nutrition. AMA Council on Food and Nutrition, Nashville, p.17-19, 1972.

NEUBERGER, A. and RICHARDS, F.F. Protein biosynthesis in mammalian tissues, II. Studies on turnover in the whole animal. In Mammalian Protein Metabolism, V.I, H.N. Munro and J.B. Allinson, Eds. Academic Press, Nova York, p.243, 1964.

NICOLAIDES, N., FEE, H., RICE, G.R. The skin surface lipids on man compared with those of eighteen species of animal. J. Invest. Dermatol., Baltimore, v.51, p.83-88, 1968.

OSBORNE, T.R., MENDEL, L.B., FERRY. A method of expressing numerically the growth promoting value of protein. J. Biol. Chem., Baltimore, v.37, p.223-225, 1990.

PARTRIGE, S.M. Elastin. Adv. Protein Chem., New York. v.17, p.227-231, 1962 .

PEARSE, A.G.E. Histochemistry, 3 ed., London Churchill, v.2, $1968,380 \mathrm{p}$.

PERRY, S.V. The structure and interactions of myosin. Prog. Biophys. Mol. Biol., New York, v.17, p.325-329, 1967. 
PIEZ, K. Molecular and agregate structure of the collagens In: PIEZ, K.A., REDDI, Extracellular matrix biochemistry. New York: Elsevier, p.83-118, 1984.

PILANCHERY, G., FINCK, C., MINEIRO, P., MOSSY, P., REVEL, A. Influence du regime alimentaire sur l'excretion urinaire del'hydroxiproline totale libre et conjugues non dialisable chez l'adults normal. Ann. Biol. Clin., Paris, v.40, p.1722,1982 .

PROCKOP, D.J. and SJOERDSMA, A. Significance of urinary hydroxyproline in man. J. Clin. Invest., New York, v.40, p.843, 1961 .

QUIROGA, M.; GUILLOT, C. Cosmetica Dermatologica Practica, El Ateneo - Buenos Aires, p.29-40, 1973.

RAMA-RAO, P.B., NORTON, H.W., JOHNSON, B.C. The amino acids composition and the nutritive value of proteins. J. Nutr., Philadelphia, v.82, p.88-, 1964.

REESE, C., MAYNE, R. Minor collagens of chicken hyaline cartilage. Biochemistry, New York, v.20, p.5443-5448, 1987.

RIGNITTER, W., SMIDT, V., WORTH, G. The evaluation of collagen metabolism by hidroxiproline in serium and urine and serium collagen and peptidase under different diets. Klin Wochenscher, Berlin, v.56, p.1001-1005, 1978. 
ROSE, W.C. Amino acid requirements of man. Fed. Proc., Baltimore, v.8, p.546-52, 1949.

ROSE, W.C., WIXOM, R.L., LOCKHART, H.B., LAMBERT, G.T. The amino acids requirements of man. J. Biol. Chem., Baltimore, v.217, p.987-993, 1955 .

ROSE, S.M. The distribution, nature and linking of sialic acid in skin protein. Biochim Biophys Acta, Amsterdam, v.74, p. 265-273, 1963 .

ROSE, P.I. Gelatin I. General properties, In: JAMESED, T.H., ed. Theory photographic process 4.ed. New York: Macmillan, 1977, p. 51-87.

RUBNER, M. The relation between the protein condition of the body and amount of protein in the diet. Arch. Anat. Physiolo., London, v.30 p.61-69, 1910.

RUDMAN, D. Cysteine and tyrosine requirements during the nutritional repletion of cirrhotic patients In: BLACKBURN, G.L., GRANT, J.P., YOUNG, V.R. eds. Amino acids: metabolism and medical applications. Littleton: PSG, 1983, p.484-496.

SAMS, W.M.,Jr. \& SMITH, J.G.,Jr., Advances in Biology of skin, Montague, w. ed., Pergamon Pess, New York, 1965, 480p. 
SASAKI, T., ARAI, K., NAGAI, Y., Growth and collagen synthesis of cultured neofibroma fibroblast. J. Dermatol., Yokohama, v.19, p.598-601, 1993.

SCHILLER, S. Connective and supporting tissues: Mucopolysaccharides of connective tissues. Annu Rev. Physiol, Palo Alto, v.28, p.137-141, 1966.

SCHIMID, T.M, CONRAD, H.E. A unique low molecular weight collagen secreted by cultured chick embryo chondrocytes. J. Biol. Chem., Baltimore, v.257, p.1244-1250, 1982.

SCHIMID, T.M, LINSENMAYER, T.F. Type $X$ collagen In: MAYNE, R., BURGESON, R.E., eds. Structure and function of collagen types Academic Press, 1987, 223-259.

SCHIMKE, R.T.; SWEENEY, E.W.; BERIN, C.M. The roles of synthesis and degradation in the control of rat liver tryptophan pyrrolase J. Biol. Chem., Baltimore, v.240, p. 322-328, 1961 .

SCHIMKE, R.T. The importance of both synthesis and degradation in control of arginase levels in rat liver. J. Biol. Chem., Baltimore, v.239, p.3808-3812, 1964 .

SCHIMKE, R.T.; SWEENEY, E.W., BERRLIM, C.M. An analysis of the kinetics of rat liver tryptophan pyrrolase induction: The significance of both enzyme synthesis and degradation. New York, v.15, p.214-217, 1964. 
SCHIMKE, R.T. Requlation of protein deqradation in mammalian tissue. in: MUNRO, H.N., ed. Mammalian protein metabolism. New york: Academic Press, 1970. v.4, p.117.

SCHOENHEIMER, R. and RITTENBERG, D. Study of intermediary metabolism of animals with aid of isotopes. Physiol. Rev., v.20, p.234, 1940 .

SHIMOKOMAKI, M., DUANCE, U.C., BAILEY, A.J. Identification of a new disulphide bonded collagen from cartilage FEBS Lett., Amsterdam, v.121, p.51-54, 1980.

SHIMOKOMAKI, M., DUANCE, V.C., BAILEY, A.J. Identification of two fuerther collagenous fraction from cartilage Biosci. Rep., v.1, p.561-570, 1981.

SHIMOKOMAKI, M. New cartilage collagens. Bristol, 1982. Tese Doutoramento - University of Bristol.

SHIMOKOMAKI, M., Ligações Cruzadas em Colágeno e Cartilagem São Paulo, 1989 - Tese Livre Doutoramento Universidade de São Paulo.

SMITH, G.G., SILVA DE SAL, B., Racemization of amino acids in dipeptides shows $\mathrm{COOH} \mathrm{NH} 2$ for nosterically hindered residues Science, Washington, v.207, p.765-772, 1980. 
SPRINSON, D.B. and RITTENBERG, D. Rate of utilization of ammonia for protein synthesis. J. Biol. Chem., Baltimore, v.180, p.707-713, 1949 .

STETTEN, M.R. Some aspects of hydroxyproline studied with aid of isotopic nitrogen. J. Biol. Chem., Baltimore, v.181, p.31-35, 1949 .

SUGAHARA, M., ARIYOSHI, S. Nonessentiality of glicine and the essential of $L$ proline in chick nutrition Agric. Biol. Chem., Tokyo, v.31, p.106-110, 1967.

SWATLAND, H.J. Structure and development in meat animals Englewood Chiff New Jersey, 1984, 70-81.

SWICK, R.W. Measurement of protein turnover in rat liver, J. Biol. Chem., Baltimore, v.231, p.751-758, 1957.

SWINGLER, G.R., LAWRIE, R.A. Mixed protein fibres from meat industry by products, Meat Sci., Barking, v.2, p.105-117, 1978 .

TAJIMA, S. e NAGAI, Y. Distribution of macromolecular components in calf dermal conective tissue. Int. Rev. Connect. Tissue Res., New York, v.7, n.2, p.65-67, 1980.

TANZER, M.L. Cross-linking of collagen. Science, Washington, v.180, p.561-565, 1973 . 
THEIS, E.R., JACOBY, T.F. Studies in animal skin protein. J. Am. Ledulner chem. Assoc., v.36, p.3/b-, 1941 .

TOMBS, M.P. The significance of meat analogus, In: COLE, D.I.A, LAWRIE, R.A., eds. Meat Proceeding. Nothingham: Master School in Agricultura Science, 1974, p.249-268.

TSCHUDY, D.P.; BACCHUS, H.; WEISSMAN, S.; WATKIN, D.M.; EUBANKS, M. and WHITE, J. Studies of the effect of dietary protein and caloric levels on the kinetics of nitrogen metabolism using $\mathrm{N}^{15}$ L-aspartic acid. J. Clin. Invest, New York, v.38, p.892-897, 1959.

VIGLIOGLIA, P.A \& RUBIN, J. Cosmiatria II Panamericana de Publicaciones, Buenos Aires, p.22-30, 1989.

VISSER, A., THOMAS, A., Review soy protein products their processing functionality, and application aspects Food Review International, New York: v.3, p.1-32, 1987.

WATERLOW, J.C. The assessment of protein nutrition and metabolism in the whole animal, with special reference to man. In Mammalian Protein Metabolism, v.3, H.N. Munro, Ed. Academic Press, Nova York, p.325, 1969. 
WATTS, J.H., BRADLEY, L., MANN, A.N. Total nitrogen urea and ammonia excretion of human male subjects fed several nonessential amino acids singly as the chief source of nonspecific nitrogen. Metabolism, Baltimore, v.14, p.504-, 1965 .

WEISBERG, M. Food products entended to improve nutrition in the developing world Adv. Food Res., New York, v.22, p.187-203, 1976.

WELSS, P.H. and KLEIN, L. The quantitative relationship of urinary peptide hydroxyproline excretion to collagen degradation. J. Clin. Invest., New York, v.48, p.1-7, 1969.

WHITMORE, R.A., JONES, H.W., WINDUS, W., NAGHSKE, J. Preparation of hide collagen for food. J. AM. Leather Chem. Assoc., v.65, p.382-, 1970 .

WIDDOWSON, E.M. Biological implications of body composition. In Body Composition in Animals and Man. National Academy of Sciences, National Research Council Publ. No. 1598, Washington, p.71, 1968 .

WILKINSON, D.I. Variability in composition of surface lipids the problem of the epidermal contribuition. J. Invest. Dermatol., Baltimore, v.52, p.339-343, 1969. 
WOESSNER, Jr.J.F. The determination of hidroxiproline in tissue and protein samples containing small proportion of this iminoacid, Arch. Biochem. Biophys., New York, v.93, p.44047,1961

WOMACK, M., ROSE, W.C. The role of proline, hydroxyproline and glutamic acid in growth. J.Biol. Chem., Baltimore, v.171, p. 37-40, 1947 .

WOOD, P.D. Technical and pharmaceutical uses of gelatins In: WARD, A.G., COURTS, A., eds. Sciences and Technology of gelatin. New York: Academic Press, 1977, 414p.

WU, L.C., BATES, P.P. Protein-lipid films as meat substitutes. J. Food Sci., Chicago, v.40, p.160-163, 1975.

YOUNG, V.R.; and SCRIMSHAW, N.S. Endogenous nitrogen metabolism and plasma free amino acids in young adults given a "protein-free" diet, Br.J.Nutr., London, v.22, p.9-12, 1968.

YOUNG, V.R. The role of skeletal and cardiac muscle in the regulation of protein metabolism. In Mammalian Protein Metabolism, v.IV, H.N. Munro, Ed. Academic Press, Nova York, p.592, 1970 .

YOUNG, V.R. The role of skeletal and cardiac muscle in the regulation of protein metabolism, In Mammalian protein Metabolism, v.4, H.N. Munro, Ed. Academic Presse, Nova York, p. 585, 1970 . 
YOUNG, R.H., LAWRIE, R.A. Utilization of edible protein from eat industry by-products and waste. I Factors influencing the extractability of protein from bovine and ovine stomach and lungs. J. Food Technol., v.9, p.69-78, $1974 \mathrm{a}$.

YOUNG, R.H., LAWRIE, R.A. Utilization of edible protein from meat industry by products and waste. II the spinning of blood plasma protein. J. Food Technol,, Oxford, v.9, p.171$177,1974 \mathrm{~b}$.

YOUNG, R.H., LAWRIE, R.A. Utilization of edible protein from eat industry by - products and waste. III. The isolation and spinning of protein from lung and stomach J. Food Technol., Oxford, v.10, p453-464, 1975 .

ZEFF, M.; KIBRICK, A.; DRESNER, E. and GRIBETZ, H.J. Excretion of hydroxyproline in patients with rheumatic and nonrheumatic diseases. J.Clin. Invest., New York, v.35, p.579$582,1956$. 